\title{
On Beyond Truth: A Theory for Evaluating Legal Scholarship
}

\author{
Edward L. Rubin $\dagger$
}

In this issue, the California Law Review presents an exchange of views on the problem of evaluation and legal thought. Professor Rubin's Article opens the discussion by suggesting that the absence of an evaluative theory has had unfortunate consequences for the development of legal scholarship. Professor Rubin contends the lack of agreed-upon criteria for considering scholarship has stunted debate over substantive issues and encouraged the use of unexamined intuition as a basis for judgment. In formulating an evaluative theory to resolve this deficiency, Professor Rubin applies the epistemological approach of several modern continental philosophers-Habermas, Gadamer, Heidegger, and Husserl. The Article recommends that scholarship be judged using the criteria of clarity, persuasiveness, significance, and applicability. Professor Rubin also suggests that evaluators consider the doubt and anxiety they feel when confronting a work from a subdiscipline that is different from their own. The Article is followed by Professor Schlag's response.

As legal academics, we are constantly engaged in the process of evaluating legal scholarship, but we have no theory of evaluation. In fact, we rarely seem to perceive the need for such a theory. We conclude that a work of scholarship is good or bad, true or false, by intuition, trusting in some undefined quality of judgment. This leads to a wide range of conceptual and practical difficulties, difficulties that have festered to produce confusion and malaise throughout the field.

Many of the most significant debates in legal scholarship involve evaluation, and many of these are repetitive and unproductive for lack of an evaluative theory. Legal scholars have argued back and forth about the value of critical legal studies and its relationship to traditional scholarship without establishing any criteria for making such determinations. ${ }^{1}$

$\dagger$ Professor, Boalt Hall School of Law, University of California, Berkeley. B.A. 1969, Princeton University; J.D. 1979, Yale University. A number of people read this Article in its various stages. I would particularly like to thank Stephen Barnett, Meir Dan-Cohen, Richard Delgado, Angela Harris, Frederick Schauer, and Pierre Sclilag for their helpful comments.

1. For discussions of the nature of critical legal scholarslip, arguments for its superiority as a mode of analysis, and criticisms of other approaches, see MARK KELMAN, A GUIDE TO CRITICAL Legal Studies (1987); James Boyle, The Politics of Reason: Critical Legal Theory and Local Social Thought, 133 U. PA. L. Rev. 685 (1985); Alan D. Freeman, Truth and Mystification in Legal Scholarship, 90 YALE L.J. 1229 (1981); Mark G. Kelman, Trashing, 36 STAN. L. REv. 293 (1984); 
They have debated the contribution that other fields, such as economics, ${ }^{2}$ literature, ${ }^{3}$ and social science, ${ }^{4}$ can make to legal thought without general rules for assessing these external contributions. The recent controversy about critical race theory suffers from the same defect. Randall Kennedy asserts that this body of work should be judged by universal criteria of merit that are apphicable to all legal scholarship. ${ }^{5}$ His critics assert that there is a distinct voice of color which rejects these criteria and should not be subjected to thein. ${ }^{6}$ But the argument cannot be

Joseph W. Singer, The Player and the Cards: Nihilism and Legal Theory, 94 YALE L.J. 1 (1984). For criticisms of critical legal studies, expressing varying degrees of ferocity and irritation, see Owen M. Fiss, The Law Regained, 74 Cornell L. Rev. 245 (1989); Allan C. Hutchinson \& Patrick J. Monahan, Law, Politics, and the Critical Legal Scholars: The Unfolding Drama of American Legal Thought, 36 STAN. L. REV. 199 (1984); Phillip E. Johnson, Do You Sincerely Want To Be Radical?, 36 STAN. L. REV. 247 (1984); Lawrence B. Solum, On the Indeterminacy Crisis. Critiquing Critical Dogma, 54 U. CHI. L. REV. 462 (1987); John Stick, Can Nihilism Be Pragmatic?, 100 HaRv. L. REV. 332 (1986).

2. See, e.g., Richard A. Posner, Economic ANalysis of Law (3d ed. 1986); Bruce A. Ackerman, Law, Economics, and the Problem of Legal Culture, 1986 DukE L.J. 929; Jules L. Coleman, Efficiency, Utility, and Wealth Maximization, 8 HofsTrA L. REv. 509 (1980); Ronald M. Dworkin, Is Wealth a Value?, 9 J. Legal STud. 191 (1980); Jeffrey L. Harrison, Egoism, Altruism, and Market Illusions: The Limits of Law and Economics, 33 UCLA L. REV. 1309 (1986); Mark G. Kelınan, Misunderstanding Social Life: A Critique of the Core Premises of "Law and Economics," 33 J. Legal Educ. 274 (1983); Lewis A. Kornhauser, The Great Image of Authority, 36 STAN. L. REV. 349 (1984).

3. See, e.g., Richard A. Posner, Law and Literature: A Misunderstood Relation (1988); JAMES B. WhITE, HeRACles' BOW (1985); JAMES B. WhITE, WhEN WORDS LOSE THEIR MEANING (1984); Charles W. Collier, The Use and Abuse of Humanistic Theory in Law: Reexamining the Assumptions of Interdisciplinary Legal Scholarship, 41 DuKE L.J. 191 (1991); Robert M. Cover, The Bonds of Constitutional Interpretation: Of the Word, the Deed, and the Role, 20 GA. L. REv. 815 (1986); Ronald Dworkin, Law as Interpretation, 60 TEX. L. REV. 527 (1982); Owen M. Fiss, Objectivity and Interpretation, 34 STAN. L. REv. 739 (1982); Micluael S. Moore, The Interpretive Turn in Modern Theory: A Turn for the Worse?, 41 STAN. L. REV. 871 (1989); Robert Weisberg, The Law-Literature Enterprise, 1 YaLE J.L. \& HumaN. 1 (1988); Robin L. West, Adjudication Is Not Interpretation: Some Reservations About the Law-as-Literature Movement, 54 TENN. L. REV. 203 (1987); J.M. Balkin, The Domestication of Law and Literature, 14 LAw \& Soc. INQUIRY 787 (1989) (reviewing POSNER, supra).

4. See, e.g., Lawrence M. Friedman, The Law and Society Movement, 38 STAN. L. Rev. 763 (1986); Stewart Macaulay, Law and the Behavioral Sciences: Is There Any There There?, 6 LAw \& Pol'y 149 (1984); Phihippe Nonet, In the Matter of Green v. Recht, 75 CALIF. L. Rev. 363 (1987); David M. Trubek, Where the Action Is: Critical Legal Studies and Empiricism, 36 STAN. L. REV. 575 (1984).

5. Randal1 L. Kennedy, Racial Critiques of Legal Academia, 102 HARV. L. REv. 1745 (1989). Kennedy presents this position as a critique of tluree legal scholars-Derrick Bell, Riclaard Delgado, and Mari Matsuda-whose work can be roughly described as critical racc tleory.

6. See, e.g., Milner S. Ball, The Legal Academy and Minority Scholars, 103 HARv. L. REV. 1855 (1990); Robin D. Barnes, Race Consciousness: The Thematic Content of Racial Distinctiveness in Critical Race Scholarship, 103 HaRv. L. REv. 1864 (1990); Leslie G. Espinoza, Masks and Other Disguises: Exposing Legal Academia, 103 HARv. L. REv. 1878 (1990); Alex M. Jolınson, Jr., The New Voice of Color, 100 YALE L.J. 2007 (1991) [hereinafter Johnson, The New Voice of Color]; Alex M. Johnson, Jr., Racial Critiques of Legal Academia: A Reply in Favor of Context, 43 STAN. L. REV. 137 (1990) [hereinafter Johnson, Racial Critiques]; Duncan Kennedy, A Cultural Pluralist Case for Affirmative Action in Legal Academia, 1990 DUKE L.J. 705; see also Scott Brewer, Introduction: Choosing Sides in the Racial Critiques Debate, 103 HARv. L. REV. 1844 (1990) (introduction to colloquy responding to Randall Kennedy's critics). 
resolved, or even fully developed, unless one knows the nature of the evaluative criteria, whether they are necessarily linked to one another, and, if not, under what circumstances each one is to be applied. In the final analysis, our entire concept of validity or value in legal scholarship depends upon our ability to develop an agreed-upon system of evaluation.

This Article is an effort to develop such a theory. The theory it proposes is grounded on the phenomenological experience of the individual evaluator; that is, it does not present an "objective" claim about truth, but rather advances criteria that a particular evaluator, with a particular set of beliefs, can apply to scholarly works. The theory is divided into two parts, one concerning works that use a normatively-based methodology shared by the author and the evaluator, and the other concerning works that begin from norms and inethodologies that differ from those of the evaluator. The justification for this phenomenological perspective, and for the division between works with shared and divergent approaches, will be given below. ${ }^{7}$

Part I describes the need for a theory of evaluation in greater detail and establishes the starting point for the theory. Part II presents the theory for evaluating works that share the evaluator's norms and methodology; in particular, it focuses on the situation where both the evaluator and the work being evaluated belong to what can be called standard legal scholarship. Part III then presents the theory for evaluating works that feature norms and inethodologies different from those of the evaluator. The paradiginatic situation is one where the evaluator accepts the norms and methodology of standard legal scholarship, but the work being evaluated begins from different ones, specifically Chicago School economic analysis, critical legal studies, feminist theory, or critical race theory.

I

\section{The Contours of an Evaluative Theory}

\section{A. The Ubiquity of Evaluation}

Evaluation is a process in which an individual work of scholarship is judged against a set of agreed-upon criteria to determine the work's validity or value. This process plays a crucial role in every academic disciphine. Whatever the criteria for excellence or truth or value, intellectual efforts must be evaluated by other scholars to determine whether they meet these criteria. As such, the evaluative process serves two primary purposes. First, it defines the boundaries of the discipline, determining what counts as knowledge and what does not. Second, it governs ordinary debates within the discipline. When scholars seek to affirm or

7. See infra Section I.C. 
refute a particular idea, they generally do so by evaluating other scholars' works.

Thus, evaluation serves as both a gatekeeper and an adjudicator, determining the boundary of the discipline and channelling the interplay of views within that boundary. To put this another way, it is evaluation which determines what is "true" in any given field, not truth which defines the method of evaluation.

The dual functions of gatekeeper and adjudicator are of course related, since the resolution of debates within a discipline will often shift its boundaries, and shifts in boundaries will affect the resolution of debates. There is thus a third, dynamic purpose of evaluation: to provide the means by which a disciphine reassesses its own evaluative criteria and evolves over the course of time. The act of evaluating other scholars' work is, in soine sense, self-critical. Whether or not the individual evaluator questions the criteria she uses for evaluation, the net effect of the evaluative process is to place the criteria themselves at issue. How much change this process generates will vary froin one field to another. ${ }^{8}$

Among academic disciplines, law is one of the most fully suffused by evaluative issues. Its boundaries are particularly permeable, its debates particularly intense, and its transformations over time particularly extensive. We are constantly in the process of contesting the field's boundaries-debating what is relevant and what is simply "not law." Moreover, one can compile an impressive list of other academic disciplines, including pohitical science, sociology, economics, philosophy, and hiterary criticisin, whose inclusion within legal scholarship is currently at issue. ${ }^{9}$ The intensity of debate within the field can be ineasured by how rarely a legal scholar reads another scholar's work simply to learn something. We generally evaluate whether such works are good or bad, right or wrong, even as we read thein for the information they contain. Finally, one can perceive dramatic transformations in legal scholarship over time, transformations that have emerged directly from the ongoing debates within the field. The boundary between legal scholarship and social science, for example, has shifted back and forth with the vicissitudes of formalism, legal reahism, legal process, and critical legal studies. ${ }^{10}$ These same intellectual events have markedly altered the criteria

8. For a general discussion of the evolution of academic fields, specifically applied to natural science, see IMre Lakatos, The Methodology of Scientific Research Programmes (John Worrall \& Gregory Currie eds., 1978).

9. See supra notes 2-4 (citing works by authors who seek to incorporate contributions from other fields within legal scholarship).

10. For general discussions of these developments, see, e.g., RoBERT B. STEVENS, LAW SCHOOL: LEgAL EDUCATION IN AMERICA FROM THE 1850S TO THE 1980s 131-41 (1983) (exploring academic calls for the use of social science techniques at American law schools from 1880 to 1930); John H. Schlegel, American Legal Realism and Empirical Social Science: From the Yale Experience, 28 BufF. L. REv. 459 (1979) (examining the rise and fall of legal realism and its effect on legal research and education); John H. Schlegel, American Legal Realism and Empirical Social Science: 
for analyzing judicial opinions, statutes, regulations, and the scholarship that attends to each of them.

Evaluation also serves as a mode of governance-an exercise of power-in academia. One's personal reputation as a scholar is heavily, if not exclusively, determined by the evaluation of one's work. Decisions to hire faculty members are often based upon evaluation of the person's work; decisions to grant tenure, to promote to full professor, and to give chairs or salary raises are almost always based on such evaluations. From the personal perspective, evaluation controls the professional life and livelihood of nearly everyone within the academic community. From the institutional perspective, it determines the membership of each institution and establishes the members' relative prestige and influence.

Just as there exists a dialectical relationship between the debates within a field and that field's boundaries, there exists a dialectical relationship between membership in the academy and the field's structure. The nature of the scholars in a given field affects the character of its investigations, the definition of its boundaries, and the extent to which the interplay between these two alters the direction of the field as a whole. ${ }^{11}$ Conversely, the topics, boundaries, and transformations of the field will have powerful effects upon decisions about membership. For better or worse, history becomes a different field if Marxists are regarded as appropriate members of the academy; biology becomes a different field if creationists are so regarded. In recent years, personal identity has jomed viewpoint as a relevant distinction. At issue now are not only the behefs of particular scholars, but also their ethmicity, gender, and sexual orientation. ${ }^{12}$ Evaluation determines which of these groups are excluded or included, marginalized or empowered. These decisions will, in turn, affect the nature of the field over time, smce every academic field is shaped largely by its empowered members.

Here again, law is one of the fields nost heavily affected by evaluative issues. Academic judgments may have somewhat less personal impact in law than in other fields, since law-trained scholars generally have other career options. But as a field, legal scholarship is inore heavily affected by evaluative judginents because these judginents are so com-

The Singular Case of Underhill Moore, 29 BUfF. L. REv. 195 (1980) (tracing Underhill Moore's use of empirical social science techniques in legal research).

11. See William C. Chase, The american Law School and the Rise of AdMinistrative Government (1982); STEvens, supra note 10, at 155-63 (detailing long-term effects of the rise and fall of legal realism).

12. Minority scholars have recently focused attention on these issues. See, e.g., DERRICK Bell, ANd We Are Not Saved: The Elusive Quest for Racial Justice (1987); Patricia J. Williams, The Alchemy of Race AND Rights (1991); Roy L. Brooks, Life After Tenure: Can Minority Law Professors Avoid the Clyde Ferguson Syndrome?, 20 U.S.F. L. REv. 419 (1986); Richard H. Chused, The Hiring and Retention of Minorities and Women on American Law School Faculties, 137 U. PA. L. REv. 537 (1988); Richard Delgado, Minority Law Professors' Lives: The Bell-Delgado Survey, 24 HaRV. C.R.-C.L. L. REv. 349 (1989). 
pletely intertwined with the subject matter of the field. Disagreement about intellectual viewpoints in biology or history can be highly controversial, but such disagreements are inore extensive in the legal field, because law is largely devoted to the study of these controversies. Similarly, questions of identity are precisely the questions legal scholars ask. One might argue that a field such as physics is only marginally affected by the race, gender, or sexual preference of its ineinbers. While it is equally painful to be excluded from any field, the effect of exclusion on the field of physics as a whole will be relatively less extensive. But the race, gender, and sexual preference of the scholar is likely to have inportant effects on law because law is about race, gender, and sexual preference; law determines, in soine sense, how other fields and other social institutions deal with these inatters. By itself, this observation does not compel any conclusion about how the evaluative process in law should work. It simply indicates that evaluation is particularly important in law because evaluation determines membership in the field, and membership is likely to have profound effects on the content of the field itself.

\section{B. The Need for an Evaluative Theory}

As Philip Kissam and Mary Coombs have observed, our current method of evaluating legal scholarship is essentially intuitive. ${ }^{13}$ The underlymg assumption is that we, as experienced scholars, can distinguish the quality of scholarly work without any methodical process, any system of analysis. But intuitionism of this sort seems seriously out of place as a strategy for scholarly evaluation. Scholars are not supposed to act as oracles or sages; they are supposed to develop precise and coinprehensible analytic frameworks which clarify existing issues and point toward new developinents. They are also supposed to engage in intellectual self-examination, rather than relying on self-satisfied assuinptions about their instinctive abilities.

Intuitive evaluation creates specific dangers and obscures significant opportunities at both the individual and the institutional levels. At the individual level, the danger may be charitably described as personal opinion, less charitably as idiosyncrasy. Since legal scholars tend to possess

13. Mary I. Coombs, Outsider Scholarship: The Law Review Stories, 63 U. Colo. L. REV. 683, 706 (1992) ("Given the long history of [legal scholarship], one might expect [evaluative] criteria to be quite highly developed and clearly articulated. One would be disappointed. They are occasionally the subject of vague discussions in the faculty lounge."); Philip C. Kissam, The Evaluation of Legal Scholarship, 63 WASH. L. REV. 221, 222 (1988) ("Without defining terms or demonstrating how certain standards are met, works of scholarship are characterized as 'original,' 'insightful,' and 'outstanding,' or conversely as 'unimaginative,' 'mechanical' and 'routine.' "). Stephen Carter, in the course of the debate over the scholar's voice and racial identity, also identifies the problem of evaluation, and suggests several evaluative criteria. Stephen L. Carter, Academic Tenure and "White Male" Standards: Some Lessons from the Ratent Law, 100 YALE L.J. 2065, 208185 (1991). Carter's criteria are noted infra notes 143, 168. 
highly individuated and strongly-held views, the scholar's intuitive assessment of a given work will often be controlled by personal reactions that cannot be justified in general terms. As evidence of this phenomenon, one need only observe the tendency of legal scholars to rate works with which they agree as excellent, and those with which they disagree as seriously lacking in analytic perspicacity. An articulated, coherent theory of evaluation provides a means of disciplining these reactions.

Many scholars may feel that it is reductiomist or demeaning to describe their views as opinions or idiosyncrasies. After all, they have developed these views through a process of reflection, they believe them to be "true," and they support their behefs with arguments that constitute their scholarly production. ${ }^{14}$ The difficulty is that scholars disagree. However certain they may be of their own position, they must concede that many of their colleagues maintain a different position, and do so with equivalent self-confidence. Of course they may conclude that their colleagues are simply wrong, but they will not be able to persuade those colleagues of this apparently obvious fact. ${ }^{15}$ Different scholars have different experiences of hife, develop different conceptual frameworks, and make different conscious choices. Thus, one scholar's or one group's substantive arguments cannot provide an overarching and generally accepted framework for evaluating the quality of legal scholarship; only an explicit theory of evaluation itself can fulfill that role. ${ }^{16}$ Legal schol-

14. It is not easy to define what legal scholars could possibly mean by truth. There are two traditional theories. The correspondence theory holds that truth consists of the correspondence between one's beliefs and the external world. See BERTRAND RUSSELL, LOGIC AND KNOWLEDGE (Robert Charles Marsh ed., 1956) [hereinafter Russell, LOGIC AND KNOWLEDGE]; BERTRAND Russell, The Problems of Philosophy (1912) [hereinafter Russell, Problems of PhILOSOPHY]. The coherence theory holds that truth is a system of internally consistent statements. See Francis H. BRadley, Appearance and Reality: A Metaphysical Essay (2d ed. London, Sonnenschein 1897); Francis H. Bradley, EsSays ON TRUTH AND Reality (1914). Thus, a familiar claim in legal scholarship, such as "Roe v. Wade was incorrectly decided," could mean that the decision's statement about the meaning of its doctrinal source does not correspond to the source's actual meaning, or that the decision does not fit with other valid decisions. While formalists often made both claims, most scholars now agree that neither is even remotely defensible. Another theory of truth is pragmatism, which holds that truth consists of usable concepts that produce identifiable results. See William James, Pragmatism: A New Name for Some Old WAYs of ThINkING (Fredson Bowers \& Ignas K. Skrupskelis eds., Harvard University Press 1975) (1907) [hereinafter James, Pragmatism]; William James, The Meaning of Truth: A Sequel To 'PragmatisM' (1909). This at least makes sense as a means of evaluating legal scholarship; it is criticized infra text accompanying notes 40-41, 180.

15. See Donald H. Gjerdingen, The Future of Legal Scholarship and the Search for a Modern Theory of Law, 35 BuFF. L. REV. 381, 398-421 (1986) (arguing that newer legal scholars, unlike their older peers, do not believe in a clear distinction between law and politics); Kissam, supra note 13, at 223-30 (noting a "diversity of values" in scholarship); Robert C. Post, Legal Scholarship and the Practice of Law, 63 U. Colo. L. Rev. 615 (1992) (noting the divergent currents in legal scholarship and their threat to a sense of disciplinary coherence); Edward L. Rubin, The Practice and Discourse of Legal Scholarship, 86 MrcH. L. REV. 1835, 1891-95 (1988) (discussing "normative conflict" within legal scholarship).

16. For other critiques of a univalent or comprehensive theory of truth in legal scholarslip, 
arship by its very nature involves interchange between those with opposing views. The failure to agree upon a substantive position does not represent an unfortunate or temporary disarray within the field, but a central feature of the field as a whole. ${ }^{17}$

Another danger that a lack of an evaluative theory creates, at the individual level, involves the use of evaluation as an instrument of power. Very often, crucial judgments about a scholar's career will be inade by a very sinall number of people. While this dilemma may not exist in constitutional law, it will apply in fields less familiar to the majority of faculty members, and will almost invariably prevail in technical fields such as tax or corporate finance. In these fields, the recominendation of a single expert will carry near-decisive weight about tenure or promotion. If that one expert reacts idiosyncratically, on the basis of a set of personal beliefs rather than recognized criteria, the decision process can be seriously skewed. Idiosyncratic evaluation can operate in either of two ways: it inay produce an unjustifiably harsh assessment, which is unfair to the person being evaluated, ${ }^{18}$ or it may produce an unjustifiably positive assessment, which is pleasant for the individual but unfair to others and harmful to the scholarly enterprise in general.

Idiosyncratic reactions not only constitute a danger but also obscure or diminish important intellectual opportunities. The evaluation of another's work involves a confrontation with it that provides one of the best opportunities to develop an awareness of one's own work and the behefs that underlie it. The scholar's conviction in her own views and their attendant methodology enables her to develop various lines of argument, to establish pathways and proceed along them. At the saine time, this very conviction may make it difficult for the scholar to reassess her views or methodology, to change direction, or to move to different levels of analysis. A theory of evaluation provides one means of doing so. By

see, e.g., Kathryn Abrams, Hearing the Call of Stories, 79 CaL1F. L. Rev. 971 (1991); Pierre Schlag, Normativity and the Politics of Form, 139 U. PA. L. REV. 801 (1991); Singer, supra note 1.

17. The fact that scholars support their personal views with substantive arguments, while essential to the scholarly debate, complicates the task of developing an evaluative thcory by eliding the separate functions of evaluation and argument. Evaluation is the assessment of the work against some set of criteria; argument is the evaluator's personal response to that work and, at the same time, the evaluator's own scholarly effort. Without a theory of evaluation we cannot grasp the relationship between the response and the evaluative process. It may be that the ability to elicit counter-arguments-or, more precisely, the ability to elicit certain types of counter-arguments in certain ways-is a mark of excellence in the original work. Alternatively, the quality of the counterarguments may simply be determined by the abilities of the evaluator and have little to do with the quality of the original work. Without a theory of evaluation there is simply no way to tell because only such a theory can separate the evaluation process from the more general process of scholarly argumentation.

18. See, e.g., ChASE, supra note 11, at 46-59, 94-135 (describing the negative assessment of Ernst Freund's work by Joseph Beale and Felix Frankfurter, and Freund's consequent loss of influence). Freund was famous; numerous unknown assistant professors never receive tenure because they adopt the "wrong" approach to their subject. 
enabling the scholar to treat works with differing views in a serious manner, evaluation throws the scholar's own views into clearer relief. ${ }^{19}$

One might assert that the dangers of idiosyncratic assessment can be avoided and the opportunity to reassess one's own work can be seized without an articulated, collerent theory of evaluation. All that is needed, one might argue, is good judgment and a conscientious attitude. But without a theory, it is simply too difficult to hold in abeyance the views on which one's lifework is based. As soon as the stimulus of another work is presented, the mental gates open up or snap shut and one's thoughts race down their pre-estabhished pathways. Most scholars, when they read a work stating views that differ from their own, can hear the counter-arguments take shape in their minds while they read. This is a natural process; both legal training and an acadeimic career strengthen the ability to rapidly and effortlessly marshall arguinents that defend one's views. One needs the discipline of theory-m this case, a theory of evaluation-to resist the tendency to be persuaded by one's own counterarguments.

The absence of a theory of evaluation creates a set of institutional problems that parallel the problems at the individual level. The institutional analogue of personal opimion or idiosyncrasy is bias. Idiosyncratic opinion can generate favorable or unfavorable reactions, as described above, but it does so in a random pattern. For example, suppose that a white, male, mainstreain scliolar writes an article about a controversial but traditional subject such as search and seizure, where the views of other scholars are widely spread across the general range of opinion. That scliolar might be the victim-or the beneficiary-of an evaluator who has strong views about the positions that the scholar adopts. One antidote is to increase the number of evaluators, so that the positive and negative reactions will balance out, producing an even-lianded, if soinewhat foggy, assessment of the work. If enougl assessments are obtained, and no one person dominates the process, the natural dispersion of views will tend to cancel out unfair effects on the scholar's career. Despite this rougl justice, however, the process does not yield a clearly articulated evaluation of his work; its unstable balance can be readily upset by one influential or aggressive participant, and it completely overlooks the conceptual opportumities of the evaluative process.

Bias occurs when the scholars who are evaluating a particular work not only have unconscious or unjustified reactions, but have reactions that tend im one particular direction. In that case, the simple expedient of increasing the number of evaluators will not work, because it will only serve to replicate the same unjustified reaction. One source of bias is

19. The notion of an evaluative theory thus bears a close relationship to Steven Winter's notion of a situated self-consciousness. See Steven L. Winter, Bull Durham and the Uses of Theory, 42 STAN. L. REV. 639 (1990). 
institutional. Here, bias is used in its most obvious, everyday sense: dislike of those who are different. ${ }^{20}$ The extent of such biases within today's academic community has been a matter of debate. ${ }^{21}$ Regardless of its present scope, bias is clearly of grave concern if the potential victims place their different identities in issue as an aspect of their scholarship. In recent years, this has occurred as both women and racial minorities have advanced the claim that they possess a different perspective on legal issues as a result of their identity. This claim has emerged in a variety of settings, but the two most clearly delineated are feminist theory and critical race theory. ${ }^{22}$ There is likely to be an institutional bias against such works because they are based on different perspectives and because their authors explicitly proclaim these differences to be a virtue. This does not mean that negative assessments of critical race theory or feminist theory

20. For general discussions of the subject, see GORDON W. AlLPORT, THE NATURE OF Prejudice (1954); BeLl, supra note 12; Kimberlé W. Crenshaw, Race, Reform and Retrenchment: Transformation and Legitimation in Antidiscrimination Law, 101 HARV. L. REV. 1331 (1988); Charles R. Lawrence III, The Id, the Ego, and Equal Protection: Reckoning with Unconscious Racism, 39 STAN. L. REv. 317 (1987); Mari J. Matsuda, Voices of America: Accent, Antidiscrimination Law, and a Jurisprudence for the Last Reconstruction, 100 YALE L.J. 1329 (1991).

Hans-Georg Gadamer, whose work serves as a major source for this Article, attempts to rehabilitate the concept of prejudice or bias. See HANs-GEORg GADAMER, TRUTH AND METHOD 235-74 (Garrett Barden \& John Cumming eds., 2d ed. 1975). He is not referring to our conventional conception of bias, however, but to the Heideggerian notion that our pre-existing, historically developed beliefs structure the way we perceive the world. There is much to be said for this position, and it will be followed here. In attaching the word "prejudice" to it, however, Gadamer is guilty of an uncharacteristic bit of intellectual sensationalism. Heidegger's "fore-structure of understanding" is preferable, and it is precisely what Gadamer intends. Id. at 239.

21. See, e.g., BELL, supra note 12, at 140-61 (racial prejudice limits the number of minorities that law faculties are willing to appoint); Derrick A. Bell, Jr., Application of the "Tipping Point" Principle to Law Faculty Hiring Policies, 10 NovA L.J. 319 (1986) (same); Carter, supra note 13, at 2074 (general range of standards used in law school has many defects, but only some standards are racist); Stephen L. Carter, The Best Black and Other Tales, 1 Reconstruction No. 1, 1990, at 6 (star system in academic hiring discriminates against minorities); Chused, supra note 12, at 539 (underrepresentation of minorities and women best explained by prejudice); Harlon L. Dalton, The Clouded Prism, 22 HARV. C.R.-C.L. L. REv. 435 (1987) (critical legal studies movement devalues and silences minority scholars); Richard Delgado, The Imperial Scholar: Reflections on a Review of Civil Rights Literature, 132 U. PA. L. REV. 561 (1984) (mainstream scholarship in civil rights ignores the work of minority scholars); Kennedy, supra note 5, at $1760-78$ (contesting validity of Bell's and Delgado's observations).

22. With regard to feminism, see Katharine T. Bartlett, Feminist Legal Methods, 103 HARv. L. REV. 829 (1990); Cynthia R. Farina, Conceiving Due Process, 3 Yale J.L. \& Feminism 189 (1991); Ann C. Scales, The Emergence of Feminist Jurisprudence: An Essay, 95 YALE L.J. 1373 (1986); Suzanna Sherry, Civic Virtue and the Feminine Voice in Constitutional Adjudication, 72 VA. L. REV. 543 (1986); Robin West, Jurisprudence and Gender, 55 U. CHI. L. REV. 1 (1988). With regard to race, see BELL, supra note 12; Richard Delgado, When a Story Is Just a Story: Does Voice Really Matter?, 76 VA. L. REV. 95 (1990); Johnson, The New Voice of Color, supra note 6; Johnson, Racial Critiques, supra note 6; Mari J. Matsuda, Looking to the Bottom: Critical Legal Studies and Reparations, 22 HARV. C.R.-C.L. L. REV. 323 (1987); Patricia J. Williams, Alchemical Notes: Reconstructing Ideals from Deconstructed Rights, 22 HARV. C.R.-C.L. L. REV. 401 (1987); see also Angela P. Harris, Race and Essentialism in Feminist Legal Theory, 42 STAN. L. REv. 581 (1990) (feminist legal theory ignores the experience of women of color). 
are necessarily incorrect. Rather, it suggests that the possibility of institutional bias is present in evaluating these positions, and that the extent of such bias cannot be assessed without an articulated theory of evaluation. ${ }^{23}$

A second and more complex source of bias is conceptual. In analyzing this bias, it is useful to distinguish between ideology and methodology. An ideology is an interlinked set of normative behefs that generate a coinprehensive vision of a given subject. ${ }^{24} \mathrm{~A}$ inethodology is an interlinked set of consciously articulated procedures that generates research and resolves substantive uncertainties in that subject. ${ }^{25}$ While the two often interact, and while methodology is, at bottom, an ideological commitment, the distinction is useful as a heuristic device for characterizing different bodies of work in the same field. Failure to recognize such a distinction would allow some ideology to capture or monopohze a methodology, thus threatening to create confusion. The behef that economics must be the tool of efficiency, ${ }^{26}$ or that deconstruction must be an instrument for social change, ${ }^{27}$ springs from confusion of this sort.

23. See Coombs, supra note 13, at 705-09; see also id. at 708 ("The misapplication of inappropriate, vague criteria to the work of outsider scholars creates problems for us even if it is not the result of any conscious discrimination."); id. at 707 ("Because the criteria are under-articulated, the test may in effect become oue of familiarity.").

24. See, e.g., LouIs ALTHUSSER, Ideology and Ideological State Apparatuses, in LENIN AND Philosophy AND Other Essays 127 (Ben Brewster trans., 1971); RAYMond Geuss, The IdeA of a Critical Theory: Habermas AND THE Frankfurt School 4-44 (1981) (providing "descriptive," "pejorative," and "positive" definitions of ideology); 2 Jürgen HABERMAS, ThE TheORY OF COMMUNICATIVE ACTION 354 (Thomas McCarthy trans., 1987) (characterizing ideology as "totalizing conceptions of order addressed to the political consciousness of comrades and partners in struggle").

25. Method generally means a series of steps which are to be followed to reach a particular result. This definition is most securely established in natural science. See, e.g., ERNEST NaGEL, The Structure of Science: Problems in the Logic of Scientific Explanation (1961); KARL. R. POPPER, THE LOGIC OF SCIENTIFIC DISCOVERY (1959). The notion that method is a pathway to truth or validity has been heavily attacked. See Paul K. Feyeraband, Against METHOD: OUTLINE OF AN ANARChISTIC THEORY OF KNOWLEDGE (1975); GADAMER, supra note 20. Most academic disciplines and subdisciplines have an identifiable method, however. For the present, "methodology" is used to identify this result-oriented feature, without asserting any claim regarding its validity. This usage follows LAKaTos, supra note 8. In fact, the present Article adopts the position that a system of evaluation cannot be derived from a particular methodology, but only by understanding and mediating between different methodologies.

26. See, e.g., POSNER, supra note 2 (championing the norm of economic efficiency and the methodology of law and economics); Jules L. Coleman, Efficiency, Exchange, and Auction: Philosophic Aspects of the Economic Approach to Law, 68 CALIF. L. REV. 221 (1980) (opposing both); Robert C. Ellickson, Suburban Growth Controls: An Economic and Legal Analysis, 86 YALE L.J. 385 (1977) (championing both); Duncan Kennedy, Cost-Benefit Analysis of Entitlement Problems: A Critique, 33 STAN. L. Rev. 387 (1981) (opposing both); Koruhauser, supra note 2, at 353-55 (arguing for the link between the two). The linkage is challenged in BRUCE A. ACKERMAN, Reconstructing american Law (1984); Alan S. Blinder, Hard Heads, Soft Hearts: TOUGH-MINDED ECONOMICS FOR A JUST SOCIETY (1987); Ackerman, supra note 2.

27. For works that make this linkage, see, e.g., Singer, supra note 1; Girardeau A. Spann, Deconstructing the Legislative Veto, 68 MINN. L. REv. 473 (1984); Mark Tushnet, Critical Legal Studies and Constitutional Law: An Essay in Deconstruction, 36 STAN. L. REV. 623 (1984). The 
Differences in both ideology and methodology-like the more general differences of race, gender, and political viewpoint-can be sources of systematic bias. ${ }^{28}$ Ideology has the interesting attribute of making opposing normative beliefs seem incorrect-not as a matter of normative debate, but as a matter of objective truth. The comprehensive quality of ideology, moreover, ineans that those who subscribe to it do not perceive it as an ideology at all, but simply as the proper way to view the world. ${ }^{29}$ When such an ideology is inaintained by the majority of scholars in an academic field, it will define the boundaries of the field and regulate debate witlin it. A theory of evaluation that provides alternative criteria for defining boundaries and regulating debate can serve as a means of controlling ideological bias.

Similarly, methodological coinmitments tend to bind scliolars to the dominant approach and generate lostihity toward alternatives. In law, this inclination is frequently reflected in complaints that different inethodologies, such as law and economics or the philosophic elements of critical legal studies, are incomprehensible or irrelevant. ${ }^{30}$ Without a theory of evaluation, such complaints are likely to be the result of institutional bias rather than sustained analysis. Methodology may seem a weaker force than ideology, but its central importance to the scliolarly enterprise results in a particularly intense commitment.

linkage is challenged in J.M. Balkin, Deconstructive Practice and Legal Theory, 96 YALE L.J. 743 (1987).

28. Here Gadamer's broad conception of prejudice is applicable. See supra note 20. Most works of scholarship have an ideology of some sort, and all have methodologies; in themselves, these constitute means for structuring understanding, rather than prejudices in Allport's sense, see supra note 20. As such they are necessary. But differences in ideology or methodology can be a fertile source of bias, depending on how people react to perceived differences. By analogy to racial bias, one might observe that every person necessarily has a physical form, and that there are inevitable differences between individuals. Some of these differences, for example, eye color, may not give rise to prejudice, but many of them do, because of the way that people rcact to them.

29. See Althusser, supra note 24; J.M. Balkin, Ideology as Constraint, 43 Stan. L. Rev. 1133 (1991).

30. With respect to critical legal studies, see Paul D. Carrington, Of Law and the River, $34 \mathrm{~J}$. LEGAL EDUC. 222 (1984) (nihilism of critical legal studies is inconsistent with the role of law schools in training professionals); Johnson, supra note 1 (critical legal studies is a disingenuous mcans of seeming radical, without favoring truly radical proposals); Louis B. Schwartz, With Gun and Camera Through Darkest CLS-Land, 36 STAN. L. REv. 413 (1984) (critical legal studies is utopian, disingenuous jurisprudence, written in a turgid, incomprehensible style and advancing grotesque, irresponsible proposals). With respect to law and economics, see Morton J. Horwitz, Law and Economics: Science or Politics?, 8 HofsTra L. Rev. 905 (1980) (law and economics is a pseudoscience and a passing fad); Kelman, supra note 2 (law and economics is based on distorted, rightwing values); Homer Kripke, Law and Economies: Measuring the Economic Efficiency of Commercial Law in a Vacuum of Fact, 133 U. PA. L. REv. 929 (1985) (law and economic scholarship is unrelated to rcal world situations); Michael J. Trebilcock, The Prospects of "Law and Economics": A Canadian Perspective, 33 J. LEGAL EDUc. 288 (1983) (judges find law and economics unusable). These broadside rejections may well contain valid and important points. The operative question, though, is how someone who adopts a harshly critical point of view can evaluate the relative merits of works from critical legal studies or law and economics when institutionally required to do so (for example, a tenure decision). 
The dangers of bias at the institutional level also carry with thein an attendant loss of opportunity. Challenges to inainstream scholarship provide a means by which a field can redefine itself, shifting its anbit of inquiry. To get beyond one's ideological or methodological assumptions requires a theory by which those assumptions can be put at issue and a process by which that theory can be consistently brought to bear on debates within the field. The point of such a theory is not to create a presumption for change; that could only be based on the odd behef that any scholarly tradition, at any given time, is probably defective. The presumption, rather, is in favor of critical re-examination of accepted premises. The task of scholars is not to divest theinselves of premises, but to justify those premises in coherent terms. Failure to do so creates a definitive presumption against change, which is as unjustifiable as a definitive presumption in its favor.

Scholars might claim that they can free theinselves froin bias by judgment or intuition, without the need for an articnlated theory. While they inay not identify their own ideology and methodology, they can certainly recognize different approaches, and might be able to overcome instinctive distrust by conscious acceptance. Even if this were possible, a serious problein wonld remain: the evaluator would lack a inethod for distinguishing among the works under consideration, and thus would have to abandon the assessinent of quality or excellence that constitutes the central purpose of evaluation. It seeins safe to assume that any body of work, whether critical legal studies, law and economics, feminisin, or critical race theory, possesses approximately the same internal range of quality as mainstreain scholarship. A failure to inake qualitative distinctions within these fields is reverse bias rather than justifiable evaluation, and creates obvious institutional probleins of its own. The real task is to make justifiable distinctions annong works with different ideological or methodological premises. This requires a theory of evaluation, not intuition or goodwill.

The process also operates in reverse. Those who are meinbers of a dissenting group will also tend to make assessments that are controlled by their own ideology and methodology. As dissenters, they are likely to be more conscious of the set of normative beliefs they share and the methods they employ. However, the dissenters may feel a need for solidarity and a sense of antagonism toward the dominant viewpoint. This can lead to a sort of party politics approach whereby the dissenters fail to make critical judgments of their own work, and are as categorically dismissive of mainstreain scholarship as the mainstream scholars are of the dissenters. ${ }^{31}$ To avoid these tendencies, the dissenters also need a theory

31. See, e.g., Alan D. Freeman \& John H. Schlegel, Sex, Power \& Silliness: An Essay on Ackerman's Reconstructing American Law, 6 CARDozo L. REV. 847 (1985) (criticizing Bruce Ackerman's book as "male-chimp display behavior," id. at 857, "aggressive male competition," id., 
of evaluation, as Kathryn Abrams and Mary Coombs have suggested. ${ }^{32}$ In fact, they need the same theory as the mamstream group. If mainstream scholars are to make justifiable distinctions among dissenting works, valuing the best of these as highly as the best of their own work, they must be persuaded that the dissenters will make the same type of judgments about mainstream scholars and about each other. Otherwise, the mamstream scholars are faced with the unappealing prospect of favoring dissent over their own position.

A theory of evaluation can become the unifying element in legal scholarship-a theory of universal validity where other unifying elements are lacking. The various groups who contest each others' views are unlikely to be persuaded that their own view is incorrect and that some other view is right. They are thus unlikely to agree about the validity, or excellence, of scholarly works if they rely on a substantive test of excellence. If these groups can adopt a shared and hence universal theory of evaluation, however, they may be able to agree upon such judgments independent of their substantive reactions. Precisely what this ineans can only be explained once the basis of the proposed theory of evaluation is presented.

\section{The Preconditions of an Evaluative Theory}

The two basic elements in any theory of evaluation are the criteria used to judge the work under consideration and the nature of the judginent. The nature of the judgment constitutes the purpose of the criteria and is thus the initial concern. This judgment is in turn determined by the purpose of the entire field. To judge a particular work, then, we need to know what scholars in the field are attempting to achieve.

In the natural sciences, virtually everyone agrees that the purpose is to describe observable phenomena of the natural world. A work that does so correctly is regarded as true and thus as a good or excellent work within the field. The criterion for truth is the identification of causal relationships and the ability to predict the future behavior of events that can occur again. ${ }^{33}$ This approach to truth is generally referred to as posi-

a quest for "intra and intergenerational sexual domination," id. at 862, and an example of "phallic anxiety," id. at 863); Fred S. McChesney, Economics, Law, and Science in the Corporate Field: A Critique of Eisenberg, 89 CoLUM. L. REv. 1530 (1989) (criticizing Melvin Eisenberg's articles on corporate law as amateur, incompetent economics that contain mischaracterizations of Eisenberg's own work). The critical legal studies movement, with its characteristic methodological selfawareness, has identified this stance as a technique. See Kelman, supra note 1 ("trashing"). But giving a name and a rationale to the blanket dismissal of work which many other scholars find effective does not alter the fact that such a dismissal forecloses conscientious evaluation.

32. Abrams, supra note 16 (recommending that feminist narratives clarify their normative positions); Coombs, supra note 13 (recommending that outsider scholarship develop standards for judging its own work).

33. This is, in effect, the correspondence theory of truth that lies at the core of the scientific method. See NAGEL, supra note 25; RuSSELl, Logic AND KNOWLEDGE, supra note 14. 
tivism. ${ }^{34}$ While the positivist conception of scientific truth has been debated-more often by philosophers than scientists ${ }^{35}$-it enjoys a high level of consensus among scientists themselves. In fact, it is so well accepted that it constitutes our general image of truth or vahidity. ${ }^{36}$ Other fields of inquiry, aspiring to the certainty of science, have adopted this image as their own. Social science in particular-the very name bespeaks its aspirations-has long measured its success by the same criteria of causation and predictability. ${ }^{37}$

But the scientific model of validity fails us completely when we turn to legal scholarship. The terms "true" and "false" seem inapplicable in this context and the ones we employ imtuitively in their place-good or bad, correct or incorrect-cannot be translated into that natural science system of validity. The reason for this is not difficult to discern. As stated above, the nature of evaluative judgment is governed by the purpose of the field as a whole. Legal scholarship, for the most part, does not share the descriptive purposes of science; even purported descriptions of existing law can rarely be measured by the criteria of causality or prediction. Most works of legal scholarship do not purport to be descriptions at all; they may rest on a description of the law, but their purpose is a different one.

The purpose of legal scholarship is most accurately described as prescription, or recommendation. Legal scliolarship generally consists of normative statements about the way that government decisions should be made. ${ }^{38}$ These statements can be understood as prescriptions addressed to the relevant decisionmaker: most frequently a judge, but also a legisla-

34. The term, with respect to natural science, is most closely associated with Karl Popper. See POPPER, supra note 25; see also RICHARD J. BERNSTEIN, BEYOND OBJECTIVISM AND RELATIVISM: SCIENCE, Hermeneutics, AND Praxis (1983). The development of positivism is discussed in JURGEN HABERMAS, KNOWLEDGE AND HUMAN INTERESTS 67-90 (Jeremy J. Shapiro trans., 1971).

35. See, e.g., Habermas, supra note 34; Edmund Husserl, The Crisis of European Sciences and Transcendental Phenomenology: AN Introduction to Phenomonological Philosophy (David Cart trans., 1970); Thomas S. Kuhn, The Structure of Scientific Revolutions (2d ed. 1970); Peter Winch, The Idea of a Social Science and Its Relation to Philosophy (1958).

36. See BERNSTEIN, supra note 34; GADAMER, supra note 20, at 5-10; HABERMAS, supra note 34 , at $67-186$.

37. See, e.g., Richard J. Bernstein, The Restructuring of Social and Political THEORY 3-54 (1976); GADAMER, supra note 20, at 3-9; WINCH, supra note 35. Of course, as all three authors argue, this approach is not necessarily correct.

38. See Paul Brest, The Fundamental Rights Controversy: The Essential Contradictions of Normative Constitutional Scholarship, 90 YALE L.J. 1063, 1067-89 (1981) (reviewing scholarly assessments of doctrine in the area of fundamental rights); George P. Fletcher, Two Modes of Legal Thought, 90 YALE L.J. 970, 995 (1981) (tracing scholarly responses to inconsistencies in case law); Friedman, supra note 4 , at 775-78 (tracing the development of the law and society movement); Rubin, supra note 15, at 1847-53 (discussing the fundamentally normative character of legal scholarship); Frederick Schauer, Judicial Self-Understanding and the Internalization of Constitutional Rules, 61 U. CoLo. L. REv. 749, 751-55 (1990) (distinguishing between description 
tor or administrator. The scholar nuay not literally be addressing the decisionnuaker, nor need a decisionmaker ever see the work in question for it to be regarded as successful. The notion of a prescription addressed to a particular decisionmaker describes the conceptual structure of the work, the way in which its arguments are formulated. When the scholar states that a case was wrongly decided, or that a better rationale was available, or that an entire line of cases rests on a defective policy, that scholar is in effect prescribing to the judge a superior decisionmaking approacl. When the scholar argues for adoption or amendment of a statute, le is framing a recommendation to a legislator. To be sure, there is a good deal of description in most legal scliolarship, and this can be evaluated in terms of trutli. ${ }^{39}$ The case sliould be correctly summarized before it is critiqued; the problem should be described before its solution is advanced. But in legal scholarslip the critique and the solution follow fast upon their descriptive predecessors, and they generally constitute the purpose of the work. In fact, since law is so intimately connected with our inost controversial issues, even works that are cast as pure description are often intended, and received, as recommendations for our current situation. The entire field crackles with normativity, and it is this characteristic that renders the scientific concept of validity so unhelpful as a basis for evaluation.

and prescription in legal scholarship); Mark Tushnet, Legal Scholarship: Its Causes and Cure, 90 YALE L.J. 1205, 1208-15 (1981) (discussing normative forms of legal scholarship).

Recently, several legal scholars have launched a spirited attack on the entire concept of normativity in legal scholarship. See Richard Delgado, Norms and Normal Science: Toward a Critique of Normativity in Legal Thought, 139 U. PA. L. REV. 933 (1991) [hereinafter Delgado, Norms and Normal Science]; Schlag, supra note 16; Pierrc Schlag, Normative and Nowhere to Go, 43 STAN. L. REV. 167 (1990). In narrow terms, this critique supports, rather than undermines, the notion that legal scholarship is predominantly normative. But Delgado and Schlag question whether this normative stance should be taken as a given, rather than assessed and rejected. See Richard Delgado, Moves, 139 U. PA. L. REV. 1071, 1072-73 (1991) (discussing and rejecting probable inainstream responses to critique of normativity); Schlag, supra, at $174 \mathrm{n} .18$ (acknowledging that "postmodemisin often treads very close to issuing some normative judgments of its own," but rationalizing this paradox by reference to the author's "effort . . . to displace, decenter, and weaken [the existing] systein of normative legal thought"). Delgado and Schlag, however, are themselves heavily normative, and their own work thus confirms the intrinsic normativity of legal scholarship. For example, Delgado asks: "Can norntative analysis, fine as it sounds, mask injustice and oppression or contribute to the maintenance of an unfair status quo?" Delgado, Norms and Normal Science, supra, at 934 . The question is: how do we know what injustice and unfairness are, and why should we assume that there is anything wrong with oppression, unless we have some normative position? The real thrust of Delgado's and Schlag's argunnent seems to be not that normative scholarship is inherently invalid, but that it is inauthentic because it is insufficiently committed to social action.

39. There are also subdisciplines, such as legal history, that adopt a inore descriptivc stance and can be evaluated according to the criteria of the fields to which they arc allied. See, e.g., William E. Nelson, Standards of Criticism, 60 TEX. L. REv. 447 (1982) (examining standards of production and evaluation in legal history); Schauer, supra note 38, at 752-54 (distinguishing the descriptive nature of legal history froin the prescriptive quality of other forms of legal scholarship). Nelson's criteria-comprehensibility, factual accuracy, and unconventionality (originality)-apply to history in general. Nelson, supra, at 477-91. 
In the absence of the system of validity derived from natural science, the main alternative available in the Anglo-American tradition is pragmatism. ${ }^{40}$ Pragmatism exphicitly abandons any claim to absolute truth and instead looks at the practical or real-world significance of the statement in question. For pragmatism, the crucial issue is not "Is it true?" but rather "What is its use?"41 The difficulty, of course, hes in the concept of usefulness. The enterprise of pragmatism implies an agreed-upon purpose, a common goal against which scholarly efforts can be judged. Pragmatism works best as an alternative to the absolutism of scientific truth. Once we agree that the purpose of science is to predict observable phenounena, pragmatism permits us to achieve that goal without becoming philosophically engaged in questions about ultimate validity. But one cannot ask about the use of a prescription without a clear idea of the prescription's purpose. In legal scholarship, questions of purpose are centrally and intensely at issue. Because the enterprise is inherently normative, pragmatism seems no better than scientific positivism in establishing criteria by which that enterprise can be evaluated.

During the course of the last century, however, continental philosophy has fashioned another alternative to positivism. This extensive body of thought includes phenomenology, ${ }^{42}$ herineneutics, ${ }^{43}$ critical theory, ${ }^{44}$ deconstruction, ${ }^{45}$ and a variety of subsidiary themes. While far too complex to be readily characterized, this work does display a general epistemological approach that seems to be shared by its separate and otherwise divergent elements. In a prior article, I have labelled this epistemological approach the "critique of methodology." 46 Central to the critique is its

40. See generally JoHN DEWEy, EXPERIENCE AND NATURE (2d ed. 1929); JAMES, Pragmatism, supta note 14; Charles Pierce, Collected Papers: Pragmatism and Pragmaticism (C. Hartshore \& P. Weiss eds., 1934). For a recent application of pragmatist thouglit to philosophic issues, see RICHaRd RorTy, Philosophy AND THE MIRROR OF NaTURE (1979).

41. See James, Pragmatism, supra note 14, at 95-113.

42. See, e.g., Husserl, supra note 35; EDMUND HuSSERL, IdEAS: GENERAL INTRODUCTION to Pure Phenomenology (W.R. Boyce Gibson trans., 1931); M. Merleau-Ponty, Phenomenology of Perception (Colin Smith trans., 1962).

43. See, e.g., GAdAMER, supra note 20; MARTIN Heidegger, Being AND Time (Jolin Macquarrie \& Edward Robinson trans., 1962).

44. See, e.g., Habermas, supra note 34; HABERMas, supra note 24; MAX Horkheimer, Critical Theory (Matthew J. O'Connell et al. trans., 1972); MAX HORKhEIMER \& ThEOdOR W. Adorno, Dialectic OF ENLIGHTENMENT (Jolin Cumming trans., 1979).

45. See, e.g., JACQUeS DeRrIDA, OF GRAMMATOLOGY (Gayatri C. Spivak trans., 1976); JACQues DerRIDA, Writing aNd Difference (Alan Bass trans., 1978). There are otlier diverse elements in this body of philosopliy as well. E.g., Michel. Foucault, THE ARChaEology of Knowledge (A.M. Sheridan Smitlı trans., 1972); Ludwig Wittgenstein, PhilosophicaI. INVESTIGATIONS (G.E.M. Anscombe trans., 3d ed. 1968).

46. See Rubin, supra note 15 , at $1838-47$. This term does not refer to modern continental philosophy itself, but to its epistemological implications. Continental philosophy as a whole is heavily metaphysical, addressing large questions, like the meaning of life, that lie beyond probleins of knowledge. The point here is not to suinınarize this entire philosophical tradition, but to isolate and apply those features that provide an alternative approach to the evaluation of academic work. 
rejection of the positivist claim that we can make objective statements about the world, that there exists some method by which we can definitively verify our observations. The alternative it proposes is that all such statements are the product of a practice among a community of scholars, a practice that exists within a specific social and historical context. ${ }^{47}$ These statements are a node of discourse, using a particular voice that can be descriptive, normative, or interpretive. ${ }^{48}$ Their validity is determimed by the niethodology that exists within the practice, each nethodology having its powers and its limits. By becoming aware of the nethodology that we employ within a given practice, we can determine the nature of that practice and the possibihities for understanding that it offers. ${ }^{49}$ Thus, understanding replaces truth as the universal value of scholarly efforts.

The critique of nethodology may seen to contain a rather pessimistic message about the value of the scholarly enterprise, but any sense of dismay is based upon false expectations born of a positivist model. The idea that there exists sone accessible, culturally imdependent description

47. See Bernstein, supra note 34 at 109-18, 223-29; Michel FouCAult, LANGUAGE, Counter-Memory, Practice: Selected Essays and Interviews 199-204 (Donald F. Bouchard ed. \& Donald F. Bouchard \& Sherry Simon trans., 1977); HANs-Georg GADAMER, What Is Practice?: The Conditions of Social Reason, in REASON IN THE AGE OF SCIENCE 69, 69-87 (Frederick G. Lawrence trans., 1981); GADAMER, supra note 20, at 274-89; JÜrGEN HABERMAS, THEORY AND PRACTICE (John Viertel trans., 1973); 1 HABERMAS, supra note 24, at 12-14, 295-319. Similar views have been advanced in Anglo-American philosophy. See, e.g., STANLEY FiSH, Is There a TeXT IN This Class?: The AUthority of Interpretive Communities (1980); KUHN, supra note 35, at 110-34; ALASDAIRE MACINTYRE, AFTER VIRTUE: A STUDY IN MORAL Theory 169-89 (1981); Dennis M. Patterson, Law's Pragmatism: Law as Practice \& Narrative, 76 VA. L. REv. 937 (1990). Fish adopts the idea of scholarship as practice, but the consensus thcory of truth that he employs is at odds with the critique of methodology. The authors of the critique do not regard consensus as the only basis for determinations of validity or value; their point, rather, is that these determinations must begin from the existing practice, and emerge from its ongoing intellectual process. This enables their theory to serve as a means to reassess and change the practice, but from the inside out, as it were. See Winter, supra note 19.

48. See 1 HABERMAS, supra note 24 , at $8-42$ (distinguishing among theoretical discourse (descriptive), practical discourse (normative), aesthetic discourse (interpretive or evaluative), therapeutic discourse (expressive), and explicative discourse). The term "discourse" itself is defined by Habermas, rather oddly, as rational argument aimed at renewed agreement in response to breakdowns in communication. 1 id. at $42,117-18$. Most writers regard all communication as constituting discourse. See, e.g., FouCAULT, supra note 45, at 21-30; HEIDEGGER, supra note 43, at 203-14; Paul Ricoeur, The Model of the Text: Meaningful Action Considered as a Text, 38 Soc. RES. 529, 530-37 (1971). With respect to scholarship, however, the definitions merge, since the element of self-awareness that Habermas incorporates in his definition is necessarily an element of scholarly interchange. One might argue that the breakdown in agreement which Habermas posits as a precondition for discourse is intrinsic to the process of legal scholarship. See supra text accompanying note 17. Thus criteria derived from Habermas, see infra Section II.A, can be seen as a means of breaking down the ordinary character of scholarship within a single subdiscipline, and creating the self-awareness that is needed for responsible evaluation.

49. See, e.g., GADAMER, supra note 20, at 235-74; CLIFFORD GEERTZ, THE INTERPRETATION OF CUltures 193-233 (1973); 1 Habermas, supra note 24, at 107-41; MaURICE MerleauPonty, Phenomenology and the Sciences of Man, in The Primacy of Perception 43, 43-95 (James M. Edie ed., 1964); WiNCH, supra note 35, at 72-109. 
of reality that provides an absolute standard for evaluation is an illusion generated by our own specific cultural context, a bit of Judeo-Christian mythology. What the critique offers in place of this illusion is a means of understanding our own scliolarly traditions and of clarifying the insiglits they offer through a process of intellectual self-awareness. ${ }^{50}$

Underlying the critique of methodology is an epistemology grounded in the personal experience of individual human beings. That experience is seen as the starting point for all intellectual imquiry, the ultimate ground-plane or referent for thouglit. ${ }^{51}$ Any claims about the world inust be built upon the foundation of mdividual experience-the "lifeworld" that the individual inhabits-for nothing else is real to that individual. ${ }^{52}$ To those familiar with the Anglo-American tradition, this position smacks of solipsism or idealisin; surely, the physical objects we perceive are real and not to be treated as inere perceptions. But continental philosophers contend that the entire distmction between perception and reality results from unjustifiable metaphysical assumptions. Our experience, or lifeworld, is reality, the inost rehable reality that is available to us; other claims about "reality" are a metaphysical construct that is inpossible to justify.

This reliance on experience does not mean that we can construct the world any way we choose. Quite the contrary-we know, again from our experience, that the perceived world is tyrannical, pressing in on us with an insistent force. There is no need to be concerned about its insubstantiality; the real philosophical problein is to free oneself from its suffocating presence, to obtain some self-awareness in the midst of this thick flux of

50. See, e.g., GADAMER, supra note 20, at 305-41; 1 HABERMAS, supra note 24, at 366-99; HORKHEIMER, supra note 44, at 209-43; HUSSERL, supra note 42, at 107-14. Self-awareness has a further function: in addition to making us more aware of our intellectual process, and thus more capable of evaluating work within our own subdiscipline, it can make us more aware of our emotional reactions, and thus more capable of evaluating works from a separate and potentially threatening subdiscipline. This is discussed infra Part III.

51. See, e.g., GADAMER, supra note 20, at 214-74 (describing effective-historical consciousness as the basis for understanding); 1 HABERMAS, supra note 24, at 11-15, 335-37 (describing communication and understanding as taking place within a lifeworld of given meanings); HeIDEgGer, supra note 43, at 91-224 (describing the mitial status of Dasein, or Being, as submerged into the "world"); HuSSERL, supra note 35, at 103-35 (describing the "natural attitude" of human beings who accept experience as a given); HUSSERL, supra note 42, at 101-11 (same).

52. See Gadamer, supra note 20, at 235-40; HANS-Georg Gadamer, The Science of the Life-World, in Philosophical Hermeneutics 182 (David E. Linge ed. \& trans., 1976); 2 HABERMAS, supra note 24, at 119-52; HUSSERL, supra note 35, at 103-89. The term "lifeworld" has become an emblem of phenomenology. See, e.g., A. SCHultz \& T. LUCKMaN, THE STRUCTURES of the Lifeworld (1973); Erwin W. Straus, Phenomenological Psychology 256-57 (Erling Eng trans., 1966) (centrality of the "everyday-life world" in psychoanalytic practice). Heidegger uses the term "world" for the saine, or similar, idea. See HEIDEGGER, supra note 43, at 78-168. This characteristic use of familiar words for unfamiliar ideas can be confusing, particulariy when Heidegger then proceeds to talk about the all-encompassing nature of the lifeworld as "the worldhood of the world." Id. at 91-95. Consequently, Husserl's term will be the one adopted in this Article. 
personal experience. ${ }^{53}$

An epistemological stance that begins from individual experience, rather than from some notion of objective truth, leads directly to the view that scholarship is an historically contextualized practice. In place of an ideal of "objective" commumication independent of the scholar's individual experience, the critique of methodology views communication as a process by which specific human beings must speak to each other from their own subjective, experiential positions. ${ }^{54}$ Such coinmurrication, therefore, is "intersubjective."ss Because it is carried on by historically grounded human beings, the commumication is itself historically grounded. We know this, of course; we know that the passing years transform yesterday's objective certainties into today's quaint inisconceptions. The critique of methodology provides us with a systematic way to capture this perception.

The great virtue of the critique of methodology for legal scholarship is that it dethrones description as the quintessential mode of scholarship. That is not to say that it obhterates the distinction between description and other modes of discourse. Rather, it recognizes the distinction as a defining element of scholarly discourse, one of the eleinents, for example, that distingnishes physics from law or literary criticisin. But the critique of methodology rejects the epistennological priority of description. According to the critique, description is no more valid or correct than is any other mode of scholarly discourse. Whatever the rules that apply in a descriptive field such as natural science-and we can assuine, for present purposes, that they are the familiar rules distinguishing true from false-they should not set the standard for other fields. ${ }^{56}$ Thus, the critique has developed a panoply of approaches to validity or value that are not bound to scientific conceptions of truth. These approaches provide

53. Heidegger's vivid image is that we are "thrown" into the world. See HeIDEgGer, supra note 43 , at $210-24$.

54. See, e.g., GADAMER, supra note 20, at 153-341; HABERMAS, supra note 34, at 67-186; HuSSERL supra note 35 , at 67-135.

55. HUSSERL, supra note 35, at 161-72; HUSSERL, supra note 42, at 94-95. "Intersubjective" is not just a fancy term for mutual. It is meant to convey both the individual nature of experience and the collective nature of social systems that, in their turn, become individual experience. Heidegger and Husserl disagreed about the relative primacy of these factors, with Husserl stressing individual experience and Heidegger stressing the social structuring of that experience. See CHARLES B. Guignon, Heidegger and the Problem of KNowledge 87-115 (1983).

56. See GADAMER, supra note 20, at 6 ("The experience of the socio-historical world cannot be raised to a science by the inductive procedure of the natural sciences."); $i d$. at 305 (hermeneutics enables "the critic and the historian [to] emerge from the self-forgetfulness to which they had been banished by a thinking for which the only criterion was the methodology of modern science"); HABERMAS, supra note 34 , at 67 (we must reject the belief "that the meaning of knowledge is defined by what the sciences do and can thus be adequately explicated through the methodological analysis of scientific procedures"); 1 HABERMAS, supra note 24, at 15 ("[T]here are obviously other types of expressions for which we have good reasons, even though they are not tied to truth or success claims."). 
the basis for an evaluative theory of prescriptive scholarship in a way that neither positivism nor pragmatism can rival. To the extent that the scholarship is imtended to be prescriptive-and only to that extent-such a theory of evaluation will apply. Descriptive or interpretive scholarship must be evaluated according to other criteria.

Because the critique of methodology is grounded upon a phenomenology of individual experience, a theory of evaluation that is based on it must begin from that same starting point. Thus, the question is how a scholar, as an individual, shonld evaluate some other scholar's work. It is important to reiterate the difference between this perspective and the perspective we inherit from our Anglo-American tradition. In our tradition, a theory of evaluation would begin with a set of general rules, articulated mdependently of any individual scholar's point of view. We might, for example, employ a general definition of originality to determime whether a particular work is "origimal." The critique of methodology adopts a different approach. It begms with the individual evaluator, and seeks to articulate the rules which that particular person should employ, given her own position and personal set of behiefs.

The relationship between the evaluator and the work being evaluated is thus the crucial issue for a theory of evaluation based on the critique. As stated above, the evaluative process is likely to be heavily affected by the degree to which the evaluator agrees or disagrees with the work under consideration. ${ }^{57}$ The two most sigmificant axes of agreement are ideology and methodology. ${ }^{58}$ There is, of course, a wide range of positions along both these axes, and the evaluator will rarely be in complete agreement with the work on either one. But the degree of agreement or disagreement varies and becomes crucially important when the disagreement rises to the level of a qualitative difference. It is in that situation that misunderstandings are likely to be greatest and systematic bias is most likely to intrude. As a presumptive matter, therefore, the evaluation of works that reflect a qualitatively different ideology and methodology from the evaluator's may require a different evaluative strategy.

Works that do not display quahitative differences from one another in either ideology or methodology can be regarded as belonging to a single subdisciplime, a distinct subset of the entire field. ${ }^{59}$ The theory of

57. See supra text accompanying notes 14-19.

58. See supra text accompanying notes 24-27.

59. The concept of qualitative difference may seem intrinsically vague. Relying on the phenomenological perspective, however, one can conclude that a work would be counted as qualitatively different, and thus belonging to a different snbdiscipline, if it seems qualitatively different to the evaluator. To discern such a difference, the evaluator draws on the set of views that are common within the practice of legal scholarship. The majority of legal scholars see themselves as part of a single enterprise-which can be called "standard legal scholarship"-and would distinguish certain intellectual movements, such as law and economics and critical legal studies, 
evaluation presented below will begin by considering the evaluation of a work within the same subdiscipline; that is, where there is no qualitative difference in ideology or methodology between the evaluator and the work. Most of the discussion will focus on the case of a practitioner of standard legal scholarship evaluating a work which fits that same description. The next part of the theory will focus on the evaluation of a work which belongs to a different subdisciplime from that of the evaluator. Again, the inam example will involve evaluation by a practitioner of standard scholarship. The initial question is how such a person should evaluate a work of law and economics or critical legal studies which, by virtue of both its ideology and methodology, belongs to different a subdisciphine. The next question is whether that same approach should be apphied to a work that einploys a qualitatively different inethodology, but not a different ideology, as is true of law and social science scholarship, or to a work that is qualitatively different in ideology but not in inethodology, as is arguably true of feminist and critical race theory.

II

\section{EVALUating WoRks Within ONE's OWN Subdiscipline}

The problem of evaluating works within our own subdiscipline is a problem of ordinary life: how do we understand each other and assess each other's statements when there are no extraordinary barriers to understanding? To approach this problem, we must generate an intellectually productive sense of distance. The process of reading and assessing a work in our own subdiscipline, like the process of hearing and interpreting a spoken statement in our own language, is so familiar that we tend to do it reflexively. To discipline the process of evaluation and free it from personal opinion or bias, we need explicit criteria of evaluation. These criteria, interposed between the reader and the text, create the distance necessary to evaluate a familiar work in some conscious and coherent fashion.

The critique of methodology includes two particularly notable theories that are useful in this enterprise: the work of Jürgen Habermas ${ }^{60}$ and Hans-Georg Gadamer. ${ }^{61}$ Both begin, as does the critique of inethodology in general, with an attack on scientific positivisin and an effort to identify an alternative basis for understanding and evaluation. While their work ultimately moves toward a generalized theory of hunnan discourse, Habermas and Gadamer have inuch to say about ordinary, dayto-day cominunication. In particular, both thinkers analyze the struc-

from that enterprise. Proponents of the latter two positions would generally agree with that distinction. Reflection suggests that standard legal scholarship is distinguished from law and economics and critical legal studies by both ideology and methodology.

60. The primary work that will be used is HABERMas, supra note 24 .

61. Primarily GADAMER, supra note 20. 
ture of ordinary communication and provide a set of criteria on which to ground judgments of validity or value.

The theories that Habermas and Gadamer develop are coniplex, and any application of those theories to the problein of evaluating legal scholarship inust clearly be limited to a few selected thenies. Relying on two sucli thinkers ratler than one inay appear to involve an unnecessary amount of conceptual nrachinery. There is, lowever, a dual character to scholarship that justifies the use of two separate philosophical systeins for a theory of evaluation. First, every work of scholarship has an explicit purpose, whether descriptive, interpretive, or, in the case of law, prescriptive. Once we liave rejected positivisn, there is no basis for privileging description over either of these other purposes. Instead, each work should be evaluated in the terms fixed by its field, as a communication within the context of that field. Second, every work of scholarship is a performance, an effort by the scholar to display those qualities that will distingmish him. ${ }^{62}$ Whether the work's status as a performance is to be judged by its success as a communication is an interesting question, but one whose answer slould not be assuined. In any event, the dual character of the scholar's work is generally apparent to the scholar hinnself as a niatter of individual experience. When creating the work, he is aware that he wants to describe, or interpret, or prescribe, but he is also aware that he wants to be recognized as an excellent scliolar.

The different einphases in Habermas' and Gadamer's theories make them useful in separating these two elements of scholarship. Habermas is centrally concerned witl communication; the origin of his work hes in critical theory, and beyond that, in Marxisin, which tends to relate abstract statenients such as scholarship to underlying social conditions. ${ }^{63}$ Gadamer, in contrast, is concerned with performance; he begins from aesthetic theory and hermeneutics, which tend to grant abstract statements their own identity or being. ${ }^{64}$ This contrast should not be overdrawn, particularly since both writers emphasize both the conceptual and historically grounded nature of human thouglit. In fact, it would be possible to find all the necessary insights about both aspects of scholarship in the work of eitlrer Habermas or Gadamer. ${ }^{65}$ But each thinker's

62. See Meir Dan-Cohen, Listeners and Eavesdroppers: Substantive Legal Theory and Its Audience, 63 U. CoLo. L. REv. 569 (1992) [hereinafter Dan-Cohen, Listeners and Eavesdroppers]; Meir Dan-Cohen, Introduction: Substantive Legal Theory and Its Audience, 10 TEL AVIV U. STUD. L. 7, 12-14 (1990) [hereinafter Dan-Cohen, Substantive Legal Theory]. In both articles, Dan-Cohen asserts that legal scholars, like stage actors, engage in dialogue with each other and are in turn overheard by an "audience" of legal practitioners and decisionmakers.

63. On the intellectual origins of Habermas' work, see ThOMAS McCARTHY, THE CRITICAL THEORY OF JÜRGEN HABERMAS (1978).

64. Gadamer, supra note 20, at 10-150; see Richard E. Palmer, Hermeneutics 162-217 (1969).

65. Habermas, for example, recognizes evaluative (aesthetic) and expressive (therapeutic) claims as basic categories of argumentation. See 1 HABERMAS, supra note 24, at 20-24. See 
works embody a distinct mood and tone, and thus highlight one aspect of the scholarly enterprise.

\section{A. Scholarship as Rational Discourse: The Criteria of Normative Clarity and Persuasiveness}

\section{Normative Clarity}

The goal that Habermas declares for his theory is to establish the conditions for a rational society. ${ }^{66}$ His project is to escape both the Marxist vise, where members of society are held in constant opposition by their different economic stations, and the more oppressive neoMarxist vise, where those oppositions are veiled, yet intensified, by the self-serving ideologies of dominant groups. ${ }^{67}$ Habermas proposes to effect this escape through rational discourse among all members of society. ${ }^{68}$ To do so, however, he must rescue rationality froin its Weberian role as an instruinent of bureaucracy, technology, and capitalisin, a role which threatens to turn rationality into just one inore ruling-class ideology. ${ }^{69}$ His solution is to treat rationality as a process froin which truth einerges, rather than one based on truths that are independent and necessarily positivist in character. ${ }^{70}$ For Habermas, then, truth is not an accurate prediction of external reality, but a potentiality and a goal of all rational human interaction.

Central to Habermas' theory is an analysis of modes of speech. Habermas asserts that one mode of speech-"communicative action"-

generally $1 \mathrm{id}$. at 273-337. Conversely, Gadamer devotes attention to the issue of communication and speech. See GADAMER, supra note 20, at 345-66.

66. 1 HABERMAS, supra note 24 , at 8-22.

67. For Habermas' critique of Marxism, see HABERMAS, supra note 34 , at 24-44; 2 HABERMAS, supra note 24 , at 334-43.

68. For Habermas, the learning processes suggested by rational discourse rely on a variety of forms of argumentation: theoretical, practical, aesthetic, therapeutic, and explicative. See 1 HABERMAS, supra note 24, at 22-42. In his earlier work, Habermas identified the process of achieving self-awareness through rational discourse as "emancipatory," and linked it with Freudian analysis. See HABERMAS, supra note 34, at 175-211, 306-16. The Theory of Communicative Action marks a shift in emphasis toward rationality and speech. Therapeutic discourse continues to be present as a mode of expressive speech, see 1 HABERMAS, supra note 24, at 20-21, 23 (fig. 2), but its role is limited to the relatively minor "form of argumentation that serves to clarify systematic selfdeception," 1 id. at 21 .

69. For Habermas' treatment of Weber's thought, see 1 HABERMAs, supra note 24, at 143-284, $345-65 ; 2$ id. at 301-31. In many ways, Max Weber is the central figure of The Theory of Communicative Action.

70. 1 id. at 75-141.

The deformations that interested Marx, Durkheim, and Weber-each in his own wayought not be attributed either to the rationalization of the lifeworld as such or to increasing system complexity as such. Neither the secularization of worldviews nor the structural differentiation of society has unavoidable pathological side effects per se. It is not the differentiation and independent development of cultural value spheres that lead to the cultural impoverishment of every-day communicative practice, but an elitist splitting off of expert cultures from contexts of communicative action in daily life.

2 id. at 330 . 
serves as the basis for rational discourse. ${ }^{71}$ The crucial distinction he makes is between action oriented to success (instrumental and strategic action) and action oriented to reaching understanding (communicative action). Success-oriented action consists of speech acts controlled by "egocentric calculations of success"; these acts are efforts by the speaker to achieve the speaker's pre-established goal by influencing the actions of an opponent. ${ }^{73}$ Such speech acts include the bureaucratic or technological discourse that modern ruling groups use to maintain their doininant position. Communicative action, in contrast, consists of an entirely distinct set of speech actions that aim not at "exerting an influence upon others," but at "commg to an understanding with thein."74 These speech acts can serve as the basis of a rational society, emancipatmg us froin both economic and ideological oppression. ${ }^{75}$

Habermas divides communicative action into three analytically separate categories: conversation, dramaturgical action, and normatively regulated action. ${ }^{76}$ By conversation he means descriptions of the world; dramaturgical action includes stateinents about one's own internal state; and normatively regulated action consists of stateinents designed to produce effects in the imtersubjective realm through an appeal to norms, and not merely through an exercise of power. Habermas asserts that any commuincative action involves all three categories, but he also states that speakers will generally be seeking understanding (the purpose of all communicative action) "first and foremost" in one of these three categories. ${ }^{77}$ To reach understanding, the hearer must know the conditions under

71. 1 id. at $75-101,284-337$.

72. 1 id. at 286.

73. For Habermas, a success-oriented attitude manifests itself in two forms of action. Strategic action is "action oriented to success . . . when we consider it under the aspect of following rules of rational choice and assess the efficacy of infuencing the decisions of a rational opponent." $1 \mathrm{id}$. at 285. Instrumental action, by contrast, is that facet of success-oriented action "when we consider it under the aspect of following technical rules of action and assess the efficiency of an intervention into a complex of circumstances and events." 1 id. Since this terminology does not correspond to the ordinary use of "instrumental" and introduces a distinction that is unnecessary for present purposes, only the term "strategic" will be used.

74. 1 id. at 285-86.

75. Habermas makes a further claim that "[r]eaching understanding is the inherent telos of human speech," 1 id. at 287, and indeed that "the use of language with an orientation to reaching understanding is the original mode of language use, upon which indirect understanding . . . and the instrumental use of language in general, are parasitic," $1 \mathrm{id}$. at 288 . For present purposes, we need not be concerned with this rather complicated claim because we are dealing with scholarship, not society in general. Virtually everyone would agree that scholarly discourse should be rational in the sense implied by Habermas' notion of communicative action.

76. 1 id. at 319-28; see also 1 id. at 18-22.

77. $1 \mathrm{id}$. at 308 . This is a subtle point, but it is also a somewhat "strategic" one, because it serves as a ready response to any commitments that Habermas makes to a particular categorization. To avoid this difficulty, we would need to know the operative distinction between an absolute categorization of speech acts, and a "first and foremost" categorization. Habermas does not provide it. In terms of the present discussion, the problem is to distinguish between descriptive and expressive speech, which falls outside the theory of evaluation presented here, and normative speech, 
which the statement can be regarded as valid. Conversational, or descriptive, action is valid if it is viewed as correctly describing the world; its validity claim, in other words, is truth. ${ }^{78}$ Dramaturgical action is valid if it is viewed by the hearer as being authentic or sincere. ${ }^{79}$ Normatively regulated action is valid if the relation it produces in the intersubjective realm is regarded as legitimate. ${ }^{80}$

Habermas' theory of rational discourse suggests one criterion for evaluating legal scholarship: whether the work in question constitutes communicative, rather than strategic, action. ${ }^{81}$ Even if one rejects his larger claims concerning rational discourse, ${ }^{82}$ one may accept that scholarship should aim to achieve understanding, not to control otlers by means of verbal threat, dissimulation, or confusion. At this level of generality, however, the notion may seem inore like an aspiration than a criterion. We can achieve greater operational specificity by considering the type of communicative action to which legal scholarship can aspire. Unlike natural scientists, legal scholars are generally not striving to describe the world; rather, the prescriptive character of their work suggests that they are trying to produce agreement in the intersubjective realm. This is accomplished, as Habermas suggests, through an appeal to norms, and Habermas exphicitly assigns colnmunicative legal statements to his subcategory of normatively regulated action. ${ }^{83}$

which the theory is designed to address. It should be sufficient to say that the theory proposed here is useful to the extent that the work under consideration is regarded as normativc in character.

78. 1 id. at 325,329 (fig. 16). Habermas also refers to this category of speech as "constative." 1 id. at 325. These terms are based on Habermas' intcrpretation of John Austin and John Searle. But they represent virtually impossible locutions, at least in English, so they will be avoided here, and the term "descriptive" will be used in their place. Natural science is the primary example of descriptive statements.

79. 1 id. at 326,329 (fig. 16).

80. 1 id.

81. Whether the law itself is strategic or communicative action is an interesting question, although one that need not be determined for the purpose of the present inquiry. Habermas takes the position that it constitutes a mixture of both modes of action. 1 id. at 35. For the contrary view, see Dan-Cohen, Listeners and Eavesdroppers, supra note 62 (law is necessarily strategic).

82. See supra note 75 .

83. Habermas has a good deal to say about the legal system in developing a theory of society that relates communicative action to social institutions. See 2 HABERMAS, supra note 24, at 171-79, 356-73. But law plays an even more central role for him by serving as a principal point of departure. He develops his categorization of communicative action and validity claims in direct contrast to Weber's idea that modemization involves the progressive disenchantment of the world, and the substitution of purely instrumental action-"purposive-rational action," in Weber's terms-for traditional, morally based systems. 1 id. at 243. See generally 1 id. at 243-73. The legal system, Habermas asserts, provides the clearest indication that Weber's view is incorrect, or incomplete. To be sure, Habermas says, modern legal rules are technical enactments, written and interpreted by specialists to achieve identifiable purposes. $1 \mathrm{id}$. at 256-60. He thus agrees with Weber about the positivity of modern law. But this does not free law from norms; all it does is disentangle positive legal enactments from their underiying normative justification and thereby throw those justifications into sharper relief. Thus, the very positivity or amorality of modern law enables us to debatc the moral foundations of the legal system more effectively. As Habermas says:

The particular accomplishment of the positivization of the legal order consists in displacing 
Central to Habermas' concept of normatively regulated action is the possibihity of mutual agreement, or consensus. He concedes that consensus is not sufficient, in philosophical or theoretical discourse, to establish the validity of normative statements. ${ }^{84}$ But, he says, "[i]n everyday life ... no one would enter into moral argumentation if he did not start from the strong presupposition that a grounded consensus could in primciple be achieved among those involved."85 Normative arguments, therefore, are designed to persuade people that a particular position "is right in relation to a normative context recognized as legitimate." extent that people are persuaded by the argument, we would describe that arguinent as a valid one. Legal scholarship is normatively regulated because a legal principle is valid if we are persuaded that it is consistent with, and supportive of, a legitimate social and political order. Prescriptive legal scholarship necessarily rests on validity claims of this nature. The particular work of scholarship need not undertake the task of persuasion; it might, for example, trace the implications of a particular legal principle or explain the best way to implement that primciple. But it necessarily relates back to such a primciple-a primciple that can be validated only in normatively regulated discourse.

This suggests that the first criterion for excellence in legal scholarship should be a primciple of normative clarity or coherence. The legal scholar can achieve understanding only by identifying his controlling norms with clarity and by explaining their relationship to his specific arguments. ${ }^{87}$ In practical terms this criterion means that every work of

problems of justification, that is, in relieving the technical administration of the law of such problems over broad expanses-but not in doing away with them. Precisely the posttraditional structure of legal consciousness sharpens the problem of justification into a question of principle that is shifted to the foundations but not thereby made to disappear.

1 id. at 261 .

Weber misses this point, in Habermas' view, because his concept of validity is limited to descriptive statements. Weber does not recognize that normative statements can also be subjected to a test for validity, and that those statements, and the contest over their validity, underlie and legitimate the modern legal system. $1 \mathrm{id}$. at 261-71. There are important forces at work, as both Weber and Marx perceived, which impede the normatively regulated communicative action that can fulfill this function. These forces, which include the increasing bureaucratization and monetarization of social systems, separate tliese social systems from the human experience of meaning and communication. 2 id. at 153-97, 332-403. Whatever the practicality of overcoming these forces in the legal system generally, the possibility of doing so represents an ideal or goal that is consistent with the movement from traditional to rational society. In the more limited domain of legal scholarship, this idcal is inore readily realized, because scholars already conceive their purpose as one of reaching understanding and the forces of bureaucratization and monetarization are weaker than they are for non-academic social structures.

84. 1 id. at 19.

85. 1 id.

86. 1 id. at 15.

87. As Habermas points out, modern legal arguments are particularly amenable to this approach, for positivism has separated and distinguished particular decisions, rules, or enactments from the norns that motivate them. 1 id. at 260-61. This separation has a dual effect. First, it makes normative clarity a real possibility since these norms stand out more clearly and their 
legal scholarship that is prescriptive in nature should clearly identify the norms on which it rehes. Sometimes, this can be accomplished in a sentence or a paragraph. A constitutional argument might be based on the norm that we should interpret the Constitution as an evolving system of structural relationships; a common law argument might begin by declaring that the law should be predictable by private parties. In other cases, stating one's normative starting point might require a more elaborate argument. Works of legal scholarship can be judged by determining whether their normative premises are stated with clarity, and whether their arguments actually flow froin those premises. The extent to which they meet this criterion is one measure of their quality.

For purposes of this criterion, it is unimportant whether the author chooses to justify his starting premise or merely identify it, whether he engages other scholars who adopt different premises or iguores those scholars and proceeds with his own discussion. These issues will becoine relevant for other criteria, but with respect to normative clarity, the crucial question is whether the reader can engage the author. She can do so as long as the author is clear about the premises of all his arguments. Difficulties arise when the author does not state the premise clearly or, worse still, when the premise is not stated at all but smuggled in along the way. ${ }^{88}$

The failure to articulate one's initial norms with clarity introduces an inevitably non-commumicative element into a work of scholarship. At best, such a work impedes the reader's understanding within the framework of a normatively regulated discipline because the reader will have difficulty perceiving or engaging the normative basis of the author's prescriptions. In other cases, the flaw resulting from this lack of normative clarity is even more serious. Often the author, whether consciously or unconsciously, is engaging in strategic action; he is trying to persuade his readers to accept the implications of a particular norm when they would otherwise reject the norm itself. The author does so by presenting those implications as empirical arguments or as implications of otlier norms that are more generally accepted than the ones that actually motivate his argument. This can be viewed as an effort to obtain a desired course of action from government decisionmakers, the explicit audience for the prescription, or to enlist legal scliolars on one's side, even though neither the decisionmaker nor the scholar really agrees witlı one's norms. In

relationship to legal rules can be reassessed more critically. Second, it makes normative clarity more relevant to professional lawyers because it constitutes a language that law-trained legislators, administrators, and private firms can understand.

88. The imagery of smuggling is quite precise here. One can smuggle contraband, such as narcotics, but one can also smuggle perfectly legitimate items, such as wristwatches. The defining characteristic of smuggling is that the material is brought in clandestimely, and not subject to established rules of inspection. Thus, there is no way to determine whether it is contraband or not, no way to gauge its quality, and no way to control its effect upon the markct. 
either case, the work involved does not contribute to understanding; it does not lead to either clear public policy or to inore intelligent scliolarly debate. ${ }^{89}$

Having identified this criterion, it seeins helpful to provide an example of its use. Furnishing examples entails a danger, however, for the process of assessing a specific work according to a general criterion of evaluation always involves an element of judgment. ${ }^{90}$ The judgments of different individuals inay diverge, but this does not necessarily inean that the criterion is invalid or indeterminate. No category, no criterion, can displace judgment and impel every individual to reach the same conclusion. The test of a criterion, ratler, is whether it provides a framework for exercising and discussing judgments, whether it replaces personal opinion, controls bias, and facilitates structured communication about the quality of a particular work.

One example of a work that can be evaluated through the criterion of normative clarity is Herbert Weclisler's celebrated article, Toward Neutral Principles of Constitutional Law. ${ }^{91}$ Weclisler beinoans the Supreine Court's lack of neutral priniciples in its decisionmaking process generally and in several specific groups of cases, including the desegregation cases. ${ }^{92}$ Inconsistency and partisan politics inay be acceptable for the political branches, Weclisler says, but judicial decisions inust rest on "reasons that in their generality and their neutrality transcend any iminediate result tliat is involved."93 The problein is that Weclisler never really tells the reader why this must be so. Instead, he relies on our negative associations with the term "politics" and upon vague appeals to the intrinsic character of the Supreine Court as a court. ${ }^{94}$ The normative judgments that motivate Weclisler's arguinent-and they are clearly strong ones-remain unstated, leading one to suspect soine inore specific dislike of the Warren Court's results. Thus, Wechsler violates, within

89. Both critical legal studies and the Chicago School of law and economics have tended to fall prey to this defect, as will be discussed in the next section. See infra text accompanying notes 20102.

90. And there are relatively few examples to rely on; that is, sustained evaluations of a particular work of scholarship on generalized, non-substantive grounds. For a recent and extremely thoughtful one, see Todd D. Rakoff, Fuller and Perdue's The Reliance Interest as a Work of Legal Scholarship, 1991 WIS. L. REV. 203.

91. Herbert Wechsler, Toward Neutral Principles of Constitutional Law, 73 HARV. L. REv. 1 (1959). According to Fred Shapiro's study, this is the second most heavily cited law review article and is remarkable for its continuing vitality. Fred R. Shapiro, The Most-Cited Law Review Articles, 73 Calif. L. Rev. 1540, 1549 \& n.43 (1985).

92. Wechsler, supra note 91 , at $31-34$.

93. Id. at 19.

94. He writes:

The courts have both the title and the duty when a case is properly before them to review the actions of the other branches in the light of constitutional provisions, even though the action involves value choices, as invariably action does. In doing so, however, they are bound to function otherwise than as a naked power organ; they participate as courts of law. Id.; see also id. at 20-26 (applying notion of neutral principles to Supreme Court doctrine). 
the ambit of his article, the very rule he would apply to judges. ${ }^{95}$

Wechsler's article may be contrasted with Alexander Bickel's The Least Dangerous Branch, ${ }^{96}$ a book that challenges Wechsler within the measured confines of the legal process movement. Bickel views the Warren Court more favorably and would allow it more control of its docket to achieve its vision and protect its legitimacy. What is important, for present purposes, is that he clearly states his guiding norm at the beginning of the book. Because the Court, unlike Congress, the President, or the executive agencies, is not elected by the people or responsible to those elected, its power is "countermajoritarian."97 Thus, Bickel establishes an explicit norm of popular control: any power exercised by government agents who are not elected by the people, or directly answerable to those elected agents, is arguably illegitimate. Bickel does not try to persuade us that the norm is legitimate; he assumes that a consensus favoring this norm already exists. His purpose, rather, is to persuade us that courts ought to behave in certain ways so that their actions will be consistent with the norm he has identified.

From this norm, and a number of subsidiary normative considerations that are also stated, Bickel derives his theory of constitutional adjudication. ${ }^{98}$ It may be objected that Bickel's work is a full-length book, not an article. ${ }^{99}$ But normative premises can be succinctly stated and, in fact, Bickel's book does so in less than a page. ${ }^{100}$ Arguing for these premises would consume more space, but the criterion of normative clarity does not require that. As long as the premises are stated, and stated fairly, the work will inhabit the realm of communicative action-it will be an effort to achieve understanding. As a result, the arguments that the work presents can be evaluated effectively, in a manner that further contributes to our understanding.

Gerald Gunther responded in kind to Bickel in an article entitled The Subtle Vices of the "Passive Virtues." ${ }^{101} \mathrm{He}$ starts where Bickel did, with a norm of popular control. But Gunther contends that Bickel's stratagems defeat the normative principle that they both espouse,

95. This criticism of Wechsler's article is similar to the one voiced by Todd Rakoff regarding another classic article, L.L. Fuller \& William R. Perdue, Jr., The Reliance Interest in Contract Damages (pts. 1 \& 2), 46 Y ALE L.J. 52, 373 (1936-37). See Rakoff, supra note 90, at 213-14.

96. Alexander M. Bickel, The least Dangerous Branch: The Supreme Court at THE BAR OF POLITICS (1962).

97. Id. at $16-23$.

98. Id. at 23-33 (Supreme Court should avoid rigid adherence to principle, and be conscious of its political and symbolic role).

99. In fact, Bickel wrote an article about the Court's power to control its docket which suffers from the same defect as Wechsler's. Alexander M. Bickel, The Supreme Court, 1960 TermForeword: The Passive Virtues, 75 HARV. L. REV. 40 (1961).

100. BICKEL, supra note 96 , at 17.

101. Gerald Gunther, The Subtle Vices of the "Passive Virtues"-A Comment on Principle and Expediency in Judicial Review, 64 Colum. L. Rev. 1 (1964). 
because the "passive virtues" conceal the basis of judicial decisions from popularly elected officials. ${ }^{102}$ Bickel's normative clarity facilitates this criticism and perhaps makes it possible. The quality of the response and its contribution to understanding are partially attributable to the clarity of the original, and are thus an indication of its merit.

\section{Persuasiveness}

The second criterion that Habermas' theory suggests is that a work of legal scholarship should be convincing. Within the realm of communicative action, one reaches understanding by means of argumentation, which Habermas defines as "that type of speech in which participants thematize contested validity claims and attempt to vindicate or criticize them through arguments." 103 An argunent, in his view, "contains reasons or grounds that are connected in a systematic way with the validity claim of a problematic expression." 104 This process is intersubjective; it occurs between human beings who begin from their own set of experiences, or hifeworld, and contains no external or transcendental referent. Habermas continues:

The "strength" of an argument is measured in a given context by the soundness of the reasons; that can be seen in, among other things, whether or not an argument is able to convince the participants in a discourse, that is, to motivate them to accept the validity claim in question. ${ }^{105}$

Since legal scholarship, to the extent that it is genuinely communicative, generally falls within Habermas' category of normatively regulated action, one might assume that the validity claim of a legal argument would be based on the perceived legitimacy of a stated norm. In that case, the argument would be convincing if it persuaded the reader to adopt its norm. There is, in fact, some legal scholarship directed toward justifying norms, generally in the fields of constitutional theory and jurisprudence. Most legal scholarship, however, prescribes means of iniplementing norms through specific governmental niechanisms, rather than

102. Id. at 22-25.

103. 1 HABERMAS, supra note 24 , at 18.

104. 1 id. (emphasis omitted). Habermas draws a sharp distinction between persuasion based on argument and persuasion based on any other factor. He states:

Participants in argumentation have to presuppose in general that the structure of their communication, by virtue of features that can be described in purely formal terms, excludes all force-whether it arises from within the process of reaching understanding itself or influences it from the outside-except the force of the better argument (and thus that it also excludes, on their part, all motives except that of a cooperative search for the truth).

1 id. at 25; see also 1 id. at 287 ("Processes of reaching understanding aim at an agreement that meets the conditions of rationally motivated assent [Zustimmung] to the content of an utterance."). This certainly seems to conform to our general understanding of scholarly argument, whatever its validity for society at large.

105. 1 id. at 18 . 
demonstrating the validity of the norms themselves. In other words, law is an applied rather than a theoretical field.

The applied character of legal scholarship creates a complexity. It means that a typical work will include a mixture of normative, descriptive, or expressive statements that depend upon the initial, normative premise. The work's main purpose may not be to argue for the premise, but to argue for subsidiary norms or to demonstrate how the starting premise can be implemented by interventions of a partially descriptive or expressive nature. For example, the scholar might argue that the policy of avoiding accidents can be implemented by holding manufacturers strictly liable for injuries caused by their products, or that the First Amendment should be interpreted in accordance with a principle of personal autonomy. The first argument treats a descriptive statement-accidents can be avoided through strict liability-as problematic and claims validity on the basis of the statement's ability to implement the stated norm. The second argument presents an expressive claim; it asks the reader to recognize, as a matter of personal experience, that a particular way of reading the Constitution is authentic. For Habermas, an authentic interpretation is one that enables us to perceive the basic meaning of the text, according to recognized general principles by which meaning is commumicated through that text. These various arguments present their claims as instrumentalities to achieve a normative goal. They remain within normative discourse, however, because their descriptive and expressive arguments are designed as elements of an overall prescription.

Because of the two-step character of these arguments, and the einphasis on the second, applicative step, the criterion for judgment cannot be whether the reader is convinced. To be convinced that a particular prescription is desirable, we inust be convinced of both the author's normative claims and his descriptive or expressive means of implementing those claims. Yet most works of legal scholarship, as stated above, do not argue on behalf of their normative premise, and it would impose unrealistic and counterproductive burdens to expect them to do so. Given the pragmatic quality of legal scholarship, the author is entitled to assume the premise, as long as it is clearly stated, and proceed to consider means for its implementation. The real test of persuasiveness, then, is whether readers would be convinced if they accepted the initial premise. In other words, if we wanted to avoid accidents, would we impose strict liability on manufacturers to implement that policy? If we agree that personal autonomy is a valid norm, can the First Amendment be authentically read to achieve it? ${ }^{106}$

106. The persuasiveness of a work of legal scholarship could conceivably derive from the authoritative position of its author rather than from the quality of its argument. For a discussion of this issue, see Frederick Schauer, The Authority of Legal Scholarship, 139 U. PA. L. REV. 1003 (1991). Schauer is not referring to authority based on one's position in a hierarchy; any 
In applying this test for persuasiveness, it helps to recall that the explicit audience for a typical work of legal scholarship is a pubhic decisionmaker. The evaluator can obtain some distance from her own norms-whether those norms agree or disagree with the author's-by asking whether a rational public decisionmaker would find the author's arguments a convincing apphication of the author's starting premise. Alternatively, the evaluator can ask whether a rational public decisionmaker who agrees with the author's premises would be convinced by the argument. ${ }^{107}$ This clearly requires some imaginative alteration of the evaluator's own reactions, a difficult but necessary process. To react directly to a scholarly work-to ask whether the work is convincing, for example-risks releasing one's idiosyncracies and biases. The process of innagining how a different person, with different views, would react produces a useful distance; it is a mode of self-discipline that is designed to avoid, or at least dampen, the effect of opimion and bias im a situation where definitive proofs are unavailable.

But a further complexity emerges. In legal scholarship, the boundary between a normative premise and a descriptive or expressive argument is highly permeable. The reason is that the field involves both the choice and the implementation of norms. Thus, a truly bizarre normative premise will undermine the descriptive or expressive arguments based upon it, however well-formulated those arguinents may be. Conversely, a well-formulated argument not only provides a convincing way to inplement the imitial premise but also lends plausibility to the premise itself. These interactions generate instabilities in the process of imaginative alteration of the evaluator's view which should themselves be recognized as valid evaluative reactions. A bizarre normative premise strams the evaluator's abihty to imagine a public decisionmaker who shares that premise or, alternatively, strams the evaluator's ability to decide whether the argument is really a convincing application of the norm. On the other hand-and more significantly-an argument that seerns to be a truly convincing application of a norm may begin to subsume the norm itself; that is, the evaluator inay find herself persuaded that the normative

persuasiveness resulting from that source would clearly be strategic. Instead, he speaks of authority based on the author's effort, process, or general reputation for expertise. Schauer properiy distinguishes the last factor from the others, for reputational considerations of this nature are extraneous to evaluation of a work of scholarship, while the other factors are indicative but not determinative. All these considerations, as Schauer correctly notes, are something other than persuasion based on the quality of the author's argument.

107. This hypothetical question should be distinguished from the simpler, less meaningful question of whether a decisionmaker was actually persuaded by a particular argument. The latter question sets too high a standard and depends on advantageous factors that bear little or no relationship to the quality of an argument. On the vagaries of scholarly influence, see Paul $D$. Carrington, Butterfy Effects: The Possibilities of Law Teaching in a Democracy, 41 Duke L.J. 741, 795-805 (1992); Stewart Macaulay, The Reliance Interest and the World Outside the Law Schools' Doors, 1991 WIS. L. REv. 247, 266-87; Schauer, supra note 38, at 755-60. 
premise is correct as well. This is acceptable because policy norms, unlike abstract philosophic propositions, are legitimately judged by their effect upon the world. In the absence of a comprehensive pliilosoplic framework, one of the best arguments for a norm is the general desirability of its practical applications.

Convincing arguments are more common than normative clarity in legal scholarship, but it is the combination of the two that best illustrates the second criterion of evaluation. An example from recent scliolarslip is Stephen Sugarman's Doing Away With Personal Injury Law. ${ }^{108}$ Sugarman begins by stating his view of the basic purposes of a legal regime dealing with accidents: safety and compensation. ${ }^{109}$ This constitutes the normative premise of his work; a reader who believes in different purposes, such as justice, may differ with Sugarman on this point. ${ }^{110}$ Sugarman then offers reasons why the current tort law system fails to fulfill his stated purposes and proposes that it be replaced witli a social insurance scheme. One can evaluate Sugarman's solutions on the basis of whetler they would convince a rational decisionmaker wlio perceived the purposes of personal injury law to be safety and compensation. For exainple, Sugarman points out how imprecise and expensive tort law is as a compensation scheme, and how many more people could be compensated through social insurance. ${ }^{111}$ If one finds these arguments convincing, inoreover, they might well affect one's clioice of norms. Justice seems like a wortliwhile purpose for tort law, but if the scheme Sugarman constructs on the basis of safety and coinpensation seeins convincing generally, one might decide to abandon that norm. ${ }^{12}$

Unconvincing arguments abound in legal scholarship, of course, but it would be difficult to illustrate thein without an excessive digression into substance. A inore interesting exainple is a well-constructed argument whose convincing quality is undermined by the bizarreness of the premise, such as Richard Posner's proposal to establish a market in babies. ${ }^{113}$ Posner's inechamisms for creating this market are restrained and unexceptional, but to decide whether they would be convincing, one

108. Stephen D. Sugarman, Doing Away with Personal Injury law: New COMPENSATION MEChANISMS FOR VICTIMS, CONSUMERS, AND BUSINESS (1989).

109. Id. at 3-54.

110. Id. at 55-72. Sugarman argues that the existing tort system does not implement a norm of justice, but he does not use justice as a basis of his recommendation.

111. Id. at 35-54, 127-52.

112. Sugarman also argues against this norm direetly, claiming that it is excessively vague: "[W]e have no clear and convincing theory of corrective justice." Id. at 57. But the persuasiveness of the regime he constructs without it is a better argument.

113. Elisabeth M. Landes \& Richard A. Posner, The Economics of the Baby Shortage, $7 \mathrm{~J}$. LEGAL STUD. 323 (1978); Richard A. Posner, The Regulation of the Market in Adoptions, 67 B.U. L. REv. 59 (1987). The suggestion was not well received. See Ronald A. Cass, Coping With Life, Law, and Markets: A Comment on Posner and the Law-and-Economics Debate, 67 B.U. L. REV. 73 (1987); Jane M. Cohen, Posnerism, Pluralism, Pessimism. 67 B.U. L. REv. 105 (1987); Tamar Frankel \& Francis H. Miller, The Inapplicability of Market Theory to Adoptions, 67 B.U. L. REV. 99 (1987); 
must accept the underlying normative premise that babies should be treated as a commodity. Imagination fails when trying to conjure up the image of a public decisionmaker who would adopt this premise. As a result, the arguments advanced become an arid, quirky enterprise, rather than an effort to achieve understanding. ${ }^{114}$

The implementation of normative premises through expressive, rather than descriptive, arguments is more common in legal scholarship, since law is so dependent on the interpretation of texts. Habermas' analysis of this issue is not fully developed, and we must rely on Gadamer to bring it to the forefront. ${ }^{115}$ But Habermas does deal witl interpretation; his approach makes sense provided that one accepts his basic principle (which he shares with Gadamer) tliat texts have no "objective" meaning, but that their meaning emerges from their interaction with a reader, or interpreter. The question becomes whether the interpretation is authentic, that is, whether one mterpreter can convince another that his reading of a given text constitutes a proper perception of its meaning. This judginent is made according to standards that the interpreters would recognize as valid ways of judging what they themselves mean when they write. ${ }^{116}$

An example of an inauthentic reading is a quasi-legendary article by Samuel Warren and Louis Brandeis, The Right to Privacy. ${ }^{117}$ Warren and Brandeis' normative premise is clearly and eloquently stated at the outset of the piece: "That the individual shall have full protection im person and in property," and that "the right to life has come to mean the right to enjoy life,- the right to be let alone."118 This right, the authors argue, is being compromised by the press, which "is overstepping in every direction the obvious bounds of propriety and of decency."119 The law should recognize a right that protects people from these depredations, Warren and Brandeis argue, a right which they brilliantly christened and delineated as the right to privacy. Tlie difficulty is that the

Robin West, Submission, Choice, and Ethics: A Rejoinder to Judge Posner, 99 HaRv. L. Rev. 1449 (1986).

114. The concept of "bizarreness" may seem unsatisfactory as a criterion for norms because it is vague and overly consensus-oriented. But without an externally established truth, a more rigorous way of judging norms does not exist. Perhaps a subgroup can articulate more definitive criteria by establishing a contrast with the dominant group. See Coombs, supra note 13, at 713 (outsider scholarship "should be judged in terms of its ability to advance the interests of the outsider community"). The difficulty, however, is that questions about the nature of the community's interests, and the best means of advancing those interests, are precisely what is at stake in the scholarship itself. It is difficult to see how one would separate such a judgment from the position that one's own substantive views are the only true ones.

115. See infra Section II.B.

116. I HABERMAS, supra note 24, at 107-20.

117. Samuel D. Warten \& Louis D. Brandeis, The Right to Privacy, 4 HARv. L. REv. 193 (1890).

118. Id. at 193.

119. Id. at 196. 
bulk of their argument is devoted not to arguing for the attractiveness of such a right, but rather to demonstrating that it is already ensconced in the common law. ${ }^{120}$ The very brilliance of the authors' insight, however, renders their interpretation of the law unconvincing. One suspects that they were anxious to clothe the new right they had formulated in precedent because they thought it would be more acceptable in that garb. This is strategic, not communicative; it creates obfuscation, rather than understanding, and represents a defect in legal scholarship.

One might contrast Warren and Brandeis' article with another that is almost equally well-known, Charles Reich's The New Property. ${ }^{121}$ Reich also begins with a clear normative premise: that liberty is a basic moral value in our normative consensus, and that property rights are a source of liberty. But the wealth that would generally serve as the basis for this right, he argues, is now dispensed by the government in the form of jobs, benefits, hicenses, franchises, contracts, subsidies, and permits. The lack of protection afforded to these new forms of wealth thus denies individuals the liberty that is part of our normative consensus. ${ }^{122}$ Reich recommends that legal protection, specifically constitutional protection, be extended to these forms of wealth, that they be recognized as new "property." 123 Implicit in this argument is the idea that the Constitution is properly interpreted to extend its protection in these cases because doing so will serve the Constitution's basic purpose. But Reich deliberately eschews a demonstration that the cases already einbody such a view; in fact, he offers his interpretation in the teeth of several countervailing Supreme Court decisions. ${ }^{124}$ The interpretation he does offer, which deals with the Constitution's meaning in changed circuinstances, seems much more authentic. It convinces us to see the document as he sees it, and thus contributes to our understanding of it.

120. See id. at 198 ("The common law secures to each individual the right of determining, ordinarily, to what extent his thoughts, sentiments, and emotions shall be communicated to others."); id. at 205 ("These considerations lead to the conclusion that the protection afforded to thoughts, sentiments, and emotions, expressed through the medium of writing or of the arts, so far as it consists in preventing publication, is merely an instance of the enforcement of the more general right of the individual to be let alone.").

121. Charles A. Reich, The New Property, 73 YALE L.J. 733 (1964). This is the fourth most cited law review article, according to Shapiro's study. Shapiro, supra note 91, at 1549.

122. Reich, supra note 121, at 733-39, 771-74.

123. Id. at 778-87.

124. Id. at 756-71. The most notable cases Reich contests are Barsky v. Board of Regents, 347 U.S. 442 (1954) (upholding power of New York State Department of Education to suspend license of criminally convicted doctor), and Flemming v. Nestor, 363 U.S. 603 (1960) (upholding termination of Social Security benefits for retroactively imposed crimes), discussed in Reich, supra note 121, at 768-71. Reich does not argue that the legal system is intrinsically opposed to recognizing such rights. He enlists as much support from precedent as he can, see id. at 739.46 , but no more than is supportable by an authentic interpretation. 


\section{B. Scholarship as Performance: The Criteria of Significance and Applicability}

As previously stated, every work of legal scholarship has the character of a performance as well as a recommendation. The typical book or law review article is exphicitly addressed to a public decisionmaker and advances certain prescriptions for that decisionmaker's task. But because it is intended to be read and judged by other legal scholars, it is also implicitly addressed to thein. The other scholars are thus intended onlookers to the author's act of addressing legal decisionmakers, as the members of the audience at a play are intended onlookers to the drama, or the spectators at a baseball game are onlookers to the contest between the teams. ${ }^{125}$ It is in this sense that a work of legal scholarship, like a drama or a baseball game, has the character of a performance, in addition to its character as a prescription.

To evaluate a work of legal scholarship as a performance, rather than as a prescription, we need an additional set of criteria. ${ }^{126}$ HansGeorg Gadamer's inajor work, Truth and Method, suggests criteria for evaluating legal scholarship im its aspect as performance that is read by an intended audience of other scholars. ${ }^{127}$ These criteria do not displace the stated criteria of coherence and persuasiveness, nor do they follow

125. See Dan-Cohen, Substantive Legal Theory, supra note 62, at 12-14; Dan-Cohen, Listeners and Eavesdroppers, supra note 62, at 588-91. Dan-Cohen proposes that legal scholars structure their discourse so as to direct it primarily at each other. The scholars would be like theater actors secking to edify and entertain an audience. According to Dan-Cohen: "[T] he theater's mission is best served when the actors ignore the audience and concentrate instead on creating and inhabiting the makebelieve world within which their fictional discourse is conducted." Dan-Cohen, Substantive Legal Theory, supra note 62, at 13. Public decisionmakers, in Dan-Cohen's scheme, play the role of the audience.

My suggestion is that legal scholars in fact structure their discourse as recommendations to public decisionmakers. This does not mean that legal scholarship cannot be viewed as addressing other legal scholars; the point, rather, is that both audiences can be addressed simultaneously, because scholarly works have the dual character of a prescription and a performance. Insisting that scholarship be structured solely as a performance would give it a rather abstruse, arid quality. It seems better that most ordinary works of legal scholarship (or jurisprudence) be structured initially as prescriptions to real-world decisionmakers. Whether these decisionmakers listen to the scholar, or are actually persuaded by then, is beside the point. The task, rather, is to develop intellectual criteria by which prescriptions can be judged. See Edward L. Rubin, What Does Legal Scholarship Say and Who Is Listening to It: A Response to Professor Dan-Cohen, 63 U. CoLo. L. REv. 731 (1992).

126. These criteria could be found in Habermas, for his analysis is certainly rich and complex enough to yield them. But he does not focus directly on the idea of performance; in fact, his discussion of expressive speech acts, to which performance clearly belongs, is developed primarily as a means of justifying the possibility of rational action outside of descriptive statements or purposive action, and not as an independent theory of art. See 1 HABERMAS, supra note 24, at 15-22.

127. For Gadamer's discussion of the performative character of art, and its relationship to basic questions about human existence, see GADAMER, supra note 20, at 91-119. This aspect of his work has not received as much attention from legal scholars as has his theory of interpreting historical texts. For an exception, see Francis J. Mootz, III, The Ontological Basis of Legal Hermeneutics: A Proposed Model of Inquiry Based on the Work of Gadamer, Habermas, and Ricoeur, 68 B.U. L. REV. 523, 527-39 (1988). 
them in a progression. Rather, they are to be used simultaneously, as a parallel framework of analysis, just as the performance aspect of the work exists simultaneously with its prescriptive character.

\section{Significance}

The starting point for Truth and Method is a theme that Gadamer shares with Habermas: the effort to identify a basis for validity that is independent of scientific positivism. The subjects that concern Gadamer are the "human sciences" or social sciences, particularly history. In his view, this field is "wholly dominated by the model of the natural sciences," 128 with the accompanying emphasis on demonstrable rules and definitive predictions. Gadainer finds an alternative concept of validity in art. To make this concept operative, however, art must itself be rescued from the modern tendency to "aestheticize" it - to treat it as a purely visceral experience of beauty. ${ }^{129}$

For Gadamer, art's model of validity is hermeneutics. ${ }^{130}$ The bestknown primciple of hermeneutics involves the hermeneutic circle; in essence, it states that one cannot understand a text without reading each part of that text, but that one cannot understand each part without a sense of the whole. ${ }^{131}$ Given this reciprocal relationship, one must proceed by stages, contmually formulating a view of the entire text and con-

128. GADAMER, supra note 20, at 5; see id. at 5-10 (introducing "the problem of method" in the human sciences).

129. Id. at 39-90. This tendency, which Gadamer traces back to Kant's Critique of Judgment, id. at 39-55, manifests itself in our cultural habit of treating visual art as something to be placed in a museum, rather than as an integral aspect of our everyday lives. Id. at 78-79. To do so is to lose the model of validity that art-the lone holdout from scientific positivism-still contains. Gadamer's project is to bring that model to the forefront, and to employ it as a means of recapturing the human sciences from the natural science model.

130. Id. at 146-50. Gadamer's account of herneneutics, and the reason it serves as a model of validity for history, is itself historical: "It is to the development of historical consciousness that herneneutics owes its central function within the human sciences." Id. at 147. As he explains, hermeneutics began as the theory of biblical interpretation and then expanded to include the interpretation of any literary text. Id. at 153-73. Several thinkers, notably Wilhelm Dilthey, then made use of hermeneutics to construct a theory for interpreting or understanding all of human action. Id. at 225-34. Hermeneutics thus becomes a theory of the social sciences in general, a theory-and this is important-that is derived from the study of art, not of natural science. That seems promising, but it is not enough for Gadamer. He follows the hermeneutic tradition past Dilthey to Heidegger, who proposed a general theory of hunan understanding. Understanding, in turn, becones the key to liuman existence itself ("being," or Dasein, in Heidegger's teruns): the process by which a person exists and can recognize tlie possibilities of existence. Gadamer uses Heidegger's "radicalization" of hermeneutics as the basis of his effort to develop a new concept of validity for the social sciences and thereby rescue them from the natural sciences: "Against the background of [Heidegger's] existential analysis of There-being [Dasein], with all its far-reaching consequences for metaphysics, the problems of a herneneutics of the human sciences suddenly look very different. [Truth and Method] is devoted to this new aspect of the hermeneutical problem." Id. at 230; see also HANS-Georg GADAMER, On the Problem of Self-Understanding, in PhILOSOPHICAL HERMENEUTICS, supra note 52, at 44; HANS-GEORG GADAMER, On the Scope and Function of Hermeneutical Reflection, in PhILOSOPhICAI HeRMEneUtics, supra note 52, at 18.

131. GADAMER, supra note 20 , at 235-36, 258-59. 
tinually revising that view as one integrates each part of it into one's general vision. ${ }^{132}$ The use of the hermeneutic circle for historical analysis takes a more general turn with a recognition that the historian is herself a part of history. Understanding an historical text thus requires the historian to recognize her own position im the continuing flow of history, rather than regarding herself as an independent, objective observer. ${ }^{133}$ "True historical thinking," says Gadamer, "must take account of its own historicality."134 In this sense we are bounded by the historical space we occupy: "Long before we understand ourselves through the process of self-examination, we understand ourselves in a self-evident way in the family, society and state in which we hive."135 Gadamer goes on, inore vividly, to declare that the "self-awareness of the mdividual is only a flickering in the closed circuits of historical life."136

In Gadamer's view, the historian's immersion within history provides the grounds for understanding an historical text. One must begni from where one is located; the ideal of understandimg a text on its own teruns, free of presuppositions, is an illusion that obscures the real process of understandimg. Who or what, Gadamer wonld ask, is doing the understandimg? ${ }^{137}$ This herineneutic process, whereby an interpreter understands a text by recognizing that she and the text share a mutual

132. Dilthey adopted this principle as a mode of understanding historical texts and history in general. Each historical text is one part of an ongoing and all-encoinpassing history. In order to understand the text, one inust understand its position within history and its relationship to history as a whole-which, of course, can be understood only by studying particular texts. See id. at 192-214 (discussing Dilthey); H.A. Hodges, The Philosophy of Wilhelm Dilthey 136-40 (1952) (discussing the hermeneutic circle and its application to historiography); PALMER, supra note 64, at 98-123 (discussing Dilthey).

133. GADAMER, supra note 20 , at 245-305.

134. Id. at 267. Heidegger's application of this hermeneutic process to all human understanding, rather than just to social science, is derived from the historicality of human thought. He asserts that understanding is not simply a task that one approaches as an independent, objective individual, but a process that depends upon one's culturally inherited ways of seeing the world, which he calls the "fore-structure of understanding." HeIDEGGER, supra note 43, at 188-95. This fore-structure is closely related to one's basic nature as a human being, because our ability to understand anything depends upon and derives from that nature. Thus, it exists prior to any effort to achieve insight through reflection. See generally id. at 169-210.

135. GADAMER, supra note 20, at 245.

136. Id. As this reference to historical life indicates, Gadamer follows Heidegger in regarding these fore-structures of understanding as essentially teinporal; Gadamer asserts that, in fact, "Heidegger's thesis was that being itself is time," $i d$. at 228 , and he treats this as Heidegger's most revolutionary insight. Since it is temporal, this fore-structure which makes understanding possible is part of history; it is part of an ongoing historical tradition, one that connects the historieal text to the historian.

137. Id. at 235-74. Of course, the text is separated from the interpreter by time, and thus it emerges from a different tradition, with a different fore-structure of understanding. But this temporal distance is not an obstacle to interpretation; rather, it makes interpretation possible by placing both the text and the interpreter at cognizable points in the historical tradition. The distance in time between text and interpretation "is not a yawning abyss, but is filled with the continuity of custom and tradition, in the light of which all that is handed down presents itself to us." Id. at 26465 . 
relationship to historical tradition, is called "the principle of effective history" by Gadamer. ${ }^{138}$ It is his theory of validity, or truth, a truth derived from art and serving as an alternative to the natural science model:

If the [literary] critic understands the given text, [i.e.,] understands himself in the text, in the way we have said, the historian also understands the great text he has himself discovered of the history of the world itself, in which every text handed down to us is but a fragment of ineaning, one letter, as it were, and he understands hinself in this great text. Both the critic and the historian thus einerge from the self-forgetfulness to which they had been banished by a thinking for which the only criterion was the methodology of modern science. Both find their true ground in effective historical consciousness. ${ }^{139}$

Gadamer's theory suggests two additional criteria for evaluating legal scholarship. The two criteria relate to the character of scholarship as a performance for other legal scholars as intended onlookers, rather than to its character as a prescription for government decisionmakers. The first of these criteria, which may be called significance, has already been identified by Philip Kissam. ${ }^{140}$ It refers to the position of the work in the continumg historical development of legal scholarship. To yield an evaluative criterion, Gadamer's theory must be adopted by analogy. His concern is with the general process of understanding; for him every work is part of an historical context, and its relationship to that context provides the basis of its meaning. For evaluative purposes, the operative question involves the manner in which the work relates to the unfolding historical development of its academic field. Is it in the field's mainstream, or on its advancing edge? Is it in a side-eddy, a backwater, or entirely out the channel? ${ }^{141}$

While the criterion of significance is not equivalent to a consensus theory of truth, it does depend upon a certain level of common agreeinent about the contours of the field. We are all imbued with the notion that today's insanity becomes tomorrow's truth, that the heretic will turn out to be a prophet. But this implies cventual acceptance and recognition; the lunatic is not part of our intellectual pantheon. As Gadamer would point out, ultimate recognition implies that the historical developinent of the field has progressed in the dissenter's direction. Thus from

138. Id. at 267 ; see also id. at $267-74$ (setting forth this principle).

139. Id. at 305 .

140. Kissam, supra note 13 , at 227-30.

141. Gadamer uses the word "tradition," see GADAMER, supra note 20, at 245-53, which should not be confused with the static concept of traditionalism. The tradition is our fore-structure of understanding, the entire set of beliefs and conceptions that serve as the basis for legal scholarship. As such it is inherently temporal, changing from one time to the next and thereby constituting the experienced present, or lifeworld, of each scholar and evaluator. The significance of a work involves the degree to which it relates to that tradition and thus contributes to our understanding. A work which alters the tradition, or challenges it, plays an important role in that tradition. 
the beginning the dissenter is part of the context, even though she may be at its forefront. Of course, determining whether someone is at the forefront or is wandering off into oblivion is a matter of judgment, but all evaluative criteria require judgment. The purpose of articulating a criterion is not to replace judgment, but to deploy it in a disciplined, productive manner.

To make this judgment one must become conscious-or, more correctly, self-conscious-of the historical and intellectual situation im which one is immersed. Gadamer asserts that we can become conscious of our own situation, and thereby gain some control over it, through a confrontation with past texts-a process of fusing our historical horizon with the horizon of the text. ${ }^{142}$ In a more limited context, like legal scholarship, the requisite awareness probably can be achieved through a confrontation with past and present texts witlim a given subject area. In any case the goal is conscious awareness; that awareness, once achieved, can then be used to assess the significance of a given work im the field's ongoing development. Without this effort, no coherent assessment of significance can be formulated. Solicited letters for tenure cases or other advancements often commit this mistake. They launch into an argument about the author's reasoning with no effort to become conscious of the context, or assess the work's place in it. This is irresponsible. An evaluative theory provides much needed guidelines toward fairer and more accurate criticism.

There are, of course, different levels of siguificance. The first, or minimal, level of significance will be met when the work belongs to the ongoing development of the field in some fashion. ${ }^{143} \mathrm{~A}$ work that lies outside the field, as then constituted, fails to meet this criterion in its entirety. If it achieves this minimal level of siguificance, the work can then be judged by its effects. In most cases, this judgment must be measured against the work's stated aspirations. A work discussing a particular subject area can only be expected to affect that area; a work that purports to describe the entire field will be judged by a more exacting standard. Of course, meeting stated aspirations need not be treated as an absolute requirement, since legal scholarship is not a contractual enterprise. If an article purports to rethink contract law, but only develops a new theory of damages, it is nonetheless a work of some importance. The article's aspirations are ultimately no more than a guideline for the

142. GADAMER, supra note 20, at 267-74. Gadamer may give too much weight to history. In legal scholarship, for example, self-awareness is certainly facilitated by a knowledge of history; one should have some sense of legal realism, the legal process school, the emergence of critical legal studies, law and economics, and other intellectual trends. But breadth of knowledge may be equally important or more so. An awareness of the field as it exists at present and an appreciation of its various themes seem equally useful in developing the requisite perspective.

143. This bears a resemblance to Stephen Carter's criterion that the scholar unust know the field. See Carter, supra note 13, at 2081-82. 
judgment that the evaluator must employ. ${ }^{144}$

Significance is a criterion that is uniquely relevant to the human sciences and thus to law, which as Gadamer suggests, can be viewed either as one of the human sciences itself or as a model for all of them. Gadamer observes that "the natural scientist writes the history of his subject in terms of the present state of knowledge. For him errors and wrong turnings are of historical interest only, because the progress of research is the self-evident criterion of his study."145 In other words, a scientific work is significant only if, and to the extent that, it is true, in the natural science usage of that term. In human science, and in nondescriptive enterprises like law, significance is an independent criterion. It refers to the work's role in the ongoing development of the field as perceived by the observer. Because the field exists in time, a work that has had significant effect on the tradition continues to be important to us; the different aspects that the tradition assumes at different times "do not simply cancel one another out as research proceeds, but are like mutually exclusive conditions that exist by themselves and combine only in us." 146

One example of a work that meets this criterion of significance is Abram Chayes' celebrated article, The Role of the Judge in Public Law Litigation. ${ }^{147}$ The article is neither strikingly original nor closely reasoned, but it derives significance from its place in the ongoing development of legal scholarship. Chayes articulates, in a clear, decisive manner, the tendency of judges to adopt a more wide-ranging and interventionist role in dealing with suits against bureaucratic governinental agencies. This tendency had been noted previously; by providing a definitive statement, Chayes unified these prior observations and crystallized them in permanent form. Scholars who read the article probably do not respond with a sense of astonishment at its insights, but with a sense of conviction about its accuracy.

Chayes' article does more than observe a trend, however; it also expresses approval of that trend and constitutes a prescription that the trend contimue. The effect of this, as Chayes explicitly recognizes, is to legitimate the process he describes. While the significance of the article is not so much im its description as in its argunient, the two are closely related. Chayes does not estabhish the propriety of interventionist public law judging by providing a convincing argument, but by communicating

144. Cf. Coombs, supra note 13, at 715 (noting the detrimental effect that "concern for scope and ambitiousness" can have on feminist and critical race scholarship. "If too many of us are paralyzed by the felt need to carry out grand theory or grand narrative, the community's goals ... will be frustrated.").

145. GADAMER, supra note 20, at 251-52.

146. Id. at 252 .

147. Abram Chayes, The Role of the Judge in Public Law Litigation, 89 HARv. L. REv. 1281 (1976). Despite its relatively recent publication date, Chayes' article is eleventh on Shapiro's mostcited list. Shapiro, supra note 91 , at $1550 \&$ n.45. 
a sense of its necessity and inevitability. One can question the normative clarity or the persuasiveness of Chayes' article, but such questions should not cast doubt on the significance of the article, for significance is a separate criterion. Chayes' article meets that criterion by contributing a category, and a normative argument in favor of that category, to our background understanding of the law. We recognize that it does so by becoming aware of the category im our own thinking, our own fore-structure of understanding.

A second example illustrates that significance is determined by a work's relationship to the ongoing development of the field, not by its persuasiveness and certainly not by its "truth." Two of the most widely reviewed books of the 1980 s were Guido Calabresi's $A$ Common Law for the Age of Statutes ${ }^{148}$ and Richard Epstein's Takings: Private Property and the Power of Eminent Domain. ${ }^{149}$ While both authors are fully versed in law and economics (Calabresi is a founder of the inoveinent), the books theinselves are standard scholarship; they rely on general legal reasoning to offer prescriptions for judicial decisionmaking. In both cases, the prescriptions are highly original and adventuresome. Calabresi recominends that judges assert the power to overrule operative statutes that, in the judge's opinion, have grown obsolete. ${ }^{150}$ Epstein perceives

148. Guido Calabresi, A Common Law for the Age of Statutes (1982). A partial list of the reviews includes: Robert Weisberg, The Calabresian Judicial Artist: Statutes and the New Legal Process, 35 Stan. L. Rev. 213 (1983); Frank M. Coffin, The Problem of Obsolete Statutes: A New Role for Courts?, 91 Yale L.J. 827 (1982) (book review); Archibald Cox, Book Review, 70 CALIF. L. REv. 1463 (1982); Alfred Hill, Calabresi: An Addendum, 82 ColuM. L. Rev. 1779 (1982) (book review); J. Willard Hurst, Book Review, 67 MINN. L. Rev. 536 (1982); Allan C. Hutclinson \& Derek Morgan, Calabresian Sunset: Statutes in the Shade, 82 CoLuM. L. REv. 1752 (1982) (book review); Steve MacIsaac, Common Sense About the Age of Statutes, 81 Mich. L. REv. 754 (1983) (book review); Abner J. Mikva, The Shifting Sands of Legal Topography, 96 Harv. L. Rev. 534 (1982) (book review); Richard Neely, Obsolete Statutes, Structural Due Process, and the Power of Courts to Demand a Second Legislative Look, 131 U. PA. L. REV. 271 (1982) (book review); Howard R. Sacks \& Lewis S. Kurlantzick, Book Review, 33 J. LEGAL Educ. 727 (1983); Sliannon C. Stimson, Calabresi on the Problem of Statutory Middle-Age: Judicial Cure or Political Prescription?, 18 HARV. C.R.-C.L. L. REv. 599 (1983) (book review); Louis Vogel, Book Review, 58 IND. L.J. 287 (1982).

149. Richard A. Epstein, Takings: Private Property and the Power of Eminent Domain (1985). The reviews include: Larry Alexander, Takings of Property and Constitutional Serendipity, 41 U. MiamI L. Rev. 223 (1986); Thomas C. Grey, The Malthusian Constitution, 41 U. Mrami L. Rev. 21 (1986); Herman Schwartz, Property Rights and the Constitution: Will the Ugly Duckling Become a Swan, 37 AM. U. L. REV. 9 (1987); Cass R. Sunstein, Two Faces of Liberalism, 41 U. MIAMI L. REv. 245 (1986); Note, Richard Epstein on the Foundations of Takings Jurisprudence, 99 HARV. L. REV. 791 (1986); Jeffrey R. Hummel, Epstein's Takings Doctrine and the Public-Goods Problem, 65 TEx. L. Rev. 1233 (1987) (book review); Mark Kelman, Taking Takings Seriously: An Essay for Centrists, 74 CALIF. L. REv. 1829 (1986) (book review); Calvin R. Massey, An Assault Upon "Takings" Doctrine: Finding New Answers in Old Theory, 63 IND. L.J. 113 (1987) (book review); Thomas W. Merrill, Rent Seeking and the Compensation Principle, 80 Nw. U. L. REV. 1561 (1986) (book review); Russell K. Osgood, Book Review, 37 J. Legal Educ. 453 (1987); Thomas Ross, Taking Takings Seriously, 80 Nw. U. L. REV. 1591 (1986) (book review); Joseph L. Sax, Takings, 53 U. CHI. L. REV. 279 (1986) (book review).

150. CAlabresi, supra note 148, at 118-19. See generally id. clis. 9-13. 
constitutional infirmities in "many of the heralded reforms and institutions of the twentieth century: zoning, rent control, workers' compensation laws, transfer payments, progressive taxation."151 The books share another characteristic that is directly relevant to the present discussion: virtually no one agrees with either of them. Despite the vast attention they have received, it is difficult to find a single reviewer who thinks that a rational decisioninaker should follow either set of prescriptions. ${ }^{152}$

It would be fruitless to try to decide whether either Calabresi's or Epstein's book is "true." Both books contain cogent arguments, but cogent counter-arguments have been raised in response to them, and we have no established framework for definitively resolving these conflicting claims. The criteria derived from Habermas also do not distinguish between these books. Both works constitute communicative action; they are serious, thoughtful works of scholarship that articulate their normative premises in a manner that contributes to the reader's understanding. But neither is convincing, as measured by responses of a rather large sample of distinguished reviewers.

The criterion of significance, however, permits further assessment of these two books, and illuminates an important distinction between them. Calabresi's work, despite its apparent lack of persuasiveness, has proved to be enormously important in the development of legal scholarship. Together with a small number of other works, it imitiated, or sigualled at the very least, a renewed interest in statutory interpretation. Since the publication of Calabresi's book, there has been a succession of articles advancing several entirely new theories of interpretation. ${ }^{153}$ This body of

151. EPSTEIN, supra note 149 , at $\mathrm{x}$.

152. But see Neely, supra note 148 (expressing guarded approval of Calebresi's proposal).

153. See, e.g., William N. Eskridge, JR. \& Philip P. Frickey, Cases and Materials on Legislation: Statutes and the Creation of Public Policy 569-828 (1988); Richard A. Posner, The Federal Courts: CRISIS AND Reform 261-93 (1985); CASS R. SUNSTEIN, AfTER THE Rights Revolution: ReCONCEIVING THE REgulatory State 111-233 (1990); T. Alexander Aleinikoff, Updating Statutory Interpretation, 87 MiCH. L. REV. 20 (1988); Frank H. Easterbrook, Statutes' Domains, 50 U. CHI. L. REV. 533 (1983); Willianı N. Eskridge, Jr., Dynamic Statutory Interpretation, 135 U. PA. L. REV. 1479 (1987) [hereinafter Eskridge, Dynamic Statutory Interpretation]; William N. Eskridge, Jr. Public Values in Statutory Interpretation, 137 U. PA. L. REv. 1007 (1989); Wilham N. Eskridge, Jr. \& Philip P. Frickey, Statutory Interpretation as Practical Reasoning, 42 STAN. L. REV. 321 (1990); Daniel A. Farber, Statutory Interpretation and Legislative Supremacy, 78 GEo. L.J. 281 (1989); Daniel A. Farber, Statutory Interpretation, Legislative Inaction, and Civil Rights, 87 Mich. L. REV. 1 (1988); Cynthia R. Farina, Statutory Interpretation and the Balance of Power in the Administrative State, 89 Colum. L. REV. 452 (1989); Donald C. Langevoort, Statutory Obsolescence and the Judicial Process: The Revisionist Role of the Courts in Federal Banking Regulation, 85 MiCH. L. REV. 672 (1987); Jonathan R. Macey, Promoting PublicRegarding Legislation Through Statutory Interpretation: An Interest Group Model, 86 CoLUM. L. REV. 223 (1986); Geoffrey P. Miller, Pragmatics and the Maxims of Interpretation, 1990 Wis. L. REv. 1179; William D. Popkin, The Collaborative Model of Statutory Interpretation, 61 S. CAL. L. REv. 541 (1988); Willianı D. Popkin, An "Internal" Critique of Justice Scalia's Theory of Statutory Interpretation, 76 MINN. L. REv. 1133 (1992); Richard A. Posner, Legal Formalism, Legal Realism, and the Interpretation of Statutes and the Constitution, 37 CASE W. RES. L. REV. 179 (1986); Richard A. Posner, Statutory Interpretation-In the Classroom and in the Courtroom, 50 U. CHI. L. 
academic writing represents the most sustained and imaginative approach to the subject since the 1930s, and possibly in the entire history of American legal scholarship. A number of these works cite Calabresi as a seminal source, and a number exphicitly adopt his insights, although continuing to express disagreement with his actual recommendation. ${ }^{154}$ One might summarize this process by describing Calabresi's book as "influential," but the process is in fact inore complex, and better captured by Gadamer's concept of historical context. The entire field of legal scholarship has evolved, and the renewed interest in statutory interpretation is part of that evolution. In true hermeneutic fashion, Calabresi's book both reffected that evolution and contributed to it.

Epstein's book is a different matter. While many of its arguinents are innovative and incisive, its general scheine of analysis seeins to coine froin a different era. Epstein begins with a summary of Hobbes' and Locke's consent theory, then argues that this theory is einbodied in the text of the Constitution and that the courts ought to enforce that text as written. ${ }^{155}$ In view of recent scholarship about the origins of the Constitution and the process of constitutional interpretation, ${ }^{156}$ this is itself a rather antiquated style of argument. Epstein's interpretation, however, is even inore antiquated: he uses the term "property" in the Fifth Amendment the way the Lochner court used it in the Fourteenth Amendment, to invalidate economic and social regulation. ${ }^{157}$ One can-

REv. 800 (1983); Kenneth W. Starr, Observations About the Use of Legislative History, 1987 DuKE L.J. 371; Cass R. Sunstein, Interpreting Statutes in the Regulatory State, 103 HARV. L. REV. 405 (1989).

It is difficult to prove a negative, but one could not compile a similarly long or impressive list for the decade prior to 1982, when Calabresi's book was published. In early 1983, Robert Weisberg wrote: "The general contemporary American view of statutory interpretation is that there is not a great deal to say about the subject." Weisberg, supra note 148 , at 213 . It is unlikely that anyone would make that statement today.

154. See, e.g., Eskridge, Dynamic Statutory Interpretation, supra note 153, at 1481 n.7 (explaining that his article's "approach is related to, but stops far short of, the proposal in G. CAlABresi, A Common LAw fOR THE AGE OF STATUTES (1982)"); Langevoort, supra note 153, at $672-73,731$ (describing Calabresi as the "most notable" proponent of activist judicial interpretation for obsolete statutes, and observing that, for "concerns about the legitimacy of the updating hypothesis, there is no answer other than Calabresi's").

155. EPSTEIN, supra note 149, at 7-31.

156. See, e.g., Charles L. Black, JR., Structure and Relationship IN Constitutional LAw (1969) (theory of judicial review based on general structure of constitution); JESSE H. CHOPER, Judicial Review and the National Political Process (1980) (theory of judicial review based on analysis of political power); JOHN H. ELY, DEMOCRACY AND DISTRUST (1980) (theory of judicial review based on analysis of representation); MICHAEL J. PERRY, THE CONSTITUTION, THE COURTS, AND HUMAN RIGHTS (1982) (theory of judicial review rejecting interpretivism); Brnce A. Ackerman, The Storrs Lectures: Discovering the Constitution, 93 YALE L.J. 1013 (1984) (recognizing shifts in interpretation as de facto amendments of the constitutional text); Jonathan R. Macey, Transaction Costs and the Normative Elements of the Public Choice Model: An Application to Constitutional Theory, 74 VA. L. REV. 471 (1988) (self-interest as the motivation for constitutional design).

157. See Lochner v. New York, 198 U.S. 45 (1905) (invalidating maximum hours legislation). 
not say that the Lochner approach was definitively refuted, or that Epstein's reformulation of it contains a logical defect. But Epstein ignores or repudiates the fact that the Lochner doctrine has been decisively rejected by both courts and scholars for at least as many years as it originally flourished. ${ }^{158}$ There remain many concerns about government regulation and inany spirited criticisins directed against various aspects of it, but these are stated in different terms and based on different premises. ${ }^{159}$ To state that Epstein's book has had little effect upon the ongoing development of legal scholarship understates the case. Takings does not seem to einerge from that process or have any meaning in relation to it. The book would probably have been significant in 1910, but it is not significant now.

As a practical matter, significance may seem to be a difficult criterion to use for evaluative purposes because it requires knowledge of the work's subsequent history. To some extent this is unavoidable. As Gadamer writes: "Everyone knows that curious impotence of our judgment where the distance in time has not given us sure criteria." 160 But the question of significance is not limited to subsequent effect; it also concerns the work's relationship to the developing historical context at the time it was written. In fact, the two questions are related, because the work's meaningfulness within the context will determine its subsequent history. The contemporary reviewers of Calabresi's and Epstein's books were aware of this conjunction, although they did not fully articulate it.

The reviewers of Calabresi's book, while generally rejecting its recoinunendation, were highly complimentary. ${ }^{161}$ They recoguized the value

158. See, e.g., Lawrence H. Tribe, American Constitutional Law 560-86 (2d ed. 1988); Gerald Gunther, The Supreme Court, 1971 Term-Foreword: In Search of Evolving Doctrine on a Changing Court: A Model for a Newer Equal Protection, 86 HARV. L. REv. 1 (1972); Robert G. McCloskey, Economic Due Process and the Supreme Court: An Exhumation and Reburial, 1962 SUP. CT. Rev. 34; Cass R. Sunstein, Lochner's Legacy, 87 Colum. L. Rev. 873 (1987).

159. Recent efforts to revive the demanding scrutiny of economic and regulatory legislation are based on other types of arguments. See, e.g., Peter H. Aranson et al, $A$ Theory of Legislative Delegation, 68 CORNELI L. REV. 1 (1982) (public choice analysis of legislative behavior); William M. Landes \& Richard A. Posner, The Independent Judiciary in an Interest-Group Perspective, 18 J.L. \& ECON. 875 (1975) (public choice analysis of incentives for efficient decisionmaking); David Schoenbrod, The Delegation Doctrine: Could the Court Give It Substance?, 83 MicH. L. REV. 1223 (1985) (institutional structure analysis). On the distinction between these approaches and Epstein's "natural law" approach, see Daniel A. Farber, Legal Pragmatism and the Constitution, 72 MiNN. L. REV. 1331, 1355-65 (1988).

160. GADAMER, supra note 20, at 265.

161. See, e.g., Coffin, supra note 148, at 841 ("To the extent that my comments have exhibited skepticism or criticisms, they have been intended to show the utmost seriousness regarding this advocacy of a new and important proposition-in order to stimulate the reading, pondering, and colloquy that the book deserves."); Cox, supra note 148, at 1463-67; Hill, supra note 148, at 1779-80 (Calabresi's "proposal is developed with great skill, marvelous clarity, and an elaboration of argument that is almost always persuasive. But is it constitutional?"); Hurst, supra note 148, at 543 . 44; Hutchinson \& Morgan, supra note 148, at 1777 ("[T]he central insight of Calabresi's work is as simple as it is important, as profound as it is provocative. . . Our substantive criticisms of Calabresi's thesis ... are not to be taken as a condemnation of his proposal."); MacIsaac, supra note 
of its emphasis on statutes and fully concurred in Calabresi's insight that statutes had come to dominate the legal landscape. The reviews of Epstein's book adopted a different tone, ranging from bewilderment to hostility. ${ }^{162}$ The reviewers sensed that they were dealing with something that did not fit; either they could not discern the author's inotivation for writing the book, or they assumed that his motivation was an inauthentic one. By identifying significance as a criterion, they might have becoine more aware of the relationship between the book and law's developing historical context, and thus better able to articulate the source of their concern.

\section{Applicability}

A second criterion that Gadamer's theory suggests is applicability. Gadamer does not envision day-to-day practicality, of course, when he uses this term. Instead, his poimt is that the historical text nust be related to the present situation of the evaluator. ${ }^{163}$ The attempt to apply a text, to relate it to the totality of one's own life, is not a step to be taken

148, at $772-73$ ("Whatever the ultimate merits of Calabresi's doctrine, his lucid and scholarly exposition is valuable for the light it casts into the misty area [that] separates legislative from judicial functions."); Mikva, supra note 148, at 544 ("[A]lthough Calabresi's suggestion is underiably intriguing, I think that both legislatures and courts should continue to play their appointed roles in our constitutional scheme."). Weisberg is one of the most critical commentators, but he describes Calabresi's book as "perhaps the inost ambitious modern attempt to define the judicial role with respect to legislation." Weisberg, supra note 148, at 216.

162. See, e.g., Alexander, supra note 149, at 232-33 ("Epstem's theory of takings represents not the serendipitous and synergistic confluence of the independent streams of constitutional interpretation, natural rights, and utility, but more likely a pretty oxbow lake, cut off froin the meandering common law stream that was its origin, and destined, unreplenished by the other streams, to dry up."); Grey, supra note 149, at 23-24 ("Takings belongs with the output of the constitutional lunatic fringe, the effusions of gold bugs, tax protestors, and gun-toting survivalists. . . Takings is a travesty of constitutional scholarship . . . ."); Kelman, supra note 149, at 1830 ("Takings is not another respectable work of constitutional interpretation, but a work roughly comparable to some survivalist's diatribe that we owe no mcome tax so long as we are paid in 'fiat currency' rather than gold backed notes."); Ross, supra note 149, at 1591-92 ("Takings is a inysterious book. . . The mystery is discovering Epstein's purpose in writing this particular book. . . . Takings will likely realize its greatest significance as a work of 'crossover scholarship,' a book for the popular, rather than the academic, audience."); Sax, supra note 149, at 279-80 ("The book is not a developed work of listory, of logic, of philosophy, or of textual analysis. . . When all else fails, it resorts to the casual assertiveness of the op-ed columnist. . . . [T] he book purports to be constitutional theory, but it makes no effort to coine to terns with more than a century of constitutional law development."); Sunstein, supra note 149, at 245 ("Takings owes its origins to the set of beliefs associated with the Lochner era ....").

Several commentators commended or defended Epstein. See Ellen F. Paul, A Reflection on Epstein and His Critics, 41 U. MIAMI L. REV. 235 (1986); Hummel, supra note 149; Merrill, supra note 149. The majority of even these commentators, lowever, expressed discomfort witl the book. See Hummel, supra note 149, at 1238 ("Unfortunately, the relentless success with which Epstein applies his principles to the hardest legal cases will interest only those who already share Epstein's classical liberal premises."); Ross, supra note 149, at 1602 ("The mystery of Takings, however, is not yet resolved. Why construct a piece of constitutional rhetoric, however conventional, that is unlikely to persuade anyone?").

163. GADAMER, supra note 20 , at 274-305. 
only after one has understood that text. It is the very essence of the process of understanding: "[K]nowledge which cannot be applied to the concrete situation remains meaningless and even risks obscuring the demands the situation makes."164 This is analogous to the more common notion that one does not understand a claim about morality or goodness unless one can apply it im one's own life situation. ${ }^{165}$

Apphicability has an obvious relationship to pragmatism: to apply something, in ordinary language, means to use it in one's own life or one's own enterprise. ${ }^{166}$ But an emphasis on usefulness, per se, may lead to the rather crass consideration of whether the evaluator would cite the work, or how often other scholars have done so. Gadamer means something different by applicability. To apply a work, to relate it to one's own hife, is the process by which one understands it, because only in one's own life, one's own experiential context, is understanding possible. ${ }^{167}$ This notion of application is not unrelated to citation-the importance of which legal scliolars readily acknowledge-but it goes beyond that simple benchmark. Rather, the evaluator must ask whether the work con-

164. Id. at 279.

165. Id. Gadamer turns to law for his model of application, just as Habermas turns to law for his model of normatively regulated action. See supra note 83. The process of interpreting a statute, which Gadamer calls, not surprisingly, legal hermeneutics, involves the application of that statute to the present situation. GADAMER, supra note 20, at 289-305. A statute, like a text, cannot be understood according to its original meaning, for its meaning exists only in the historical process by which the past is connected to the present. Applying the statute is neither a distortion of the statute's meaning nor a utilization of that meaning. Rather, it is the act of rendering the statutory language meaningful, which means, necessarily, meaningful to us.

William Eskridge has insightfully explored the implications of Gadamer's theory for statutory interpretation. William N. Eskridge, Jr., Gadamer/Statutory Interpretation, 90 CoLUM. L. ReV. 609 (1990). For Gadamer, however, legal hermeneutics is not limited to this context, but rather serves as an example of his general project. "Legal hermeneutics is able to point out what the real procedure of the human sciences is. Here we have the model for the relationship between the past and present that we are seeking." GADAMER, supra note 20, at 292 . The perceived need to apply one's interpretation of a statute to one's present situation, writes Gadamer, may seem driven by the statute's practical effeet, and by the fact that it constitutes a law in force. In fact, he asserts, that application is driven by the process of understanding itself, and is equally relevant to any text. Such application is the basic means by which we establish the text's validity, or truth. Id. at 292-93.

Having identified the process by which the interpreter relates a text to her own situation, Gadamer proceeds to consider how that interpreter opens herself to the meaning of the text. This leads him, in turn, to a consideration of the linguistic nature of understanding and, following Heidegger agaim, to a hermeneutic theory that "points to a universal ontological structure, namely to the basic nature of everything to which understanding can be directed." Id. at 431-32. This argument will not be pursued here, just as Habermas' argument about a universal theory of society was not pursued. It is unnecessary for present purposes because we are dealing with the evaluation of scholarship within one's own subdiscipline, an issue that can be approached on purely epistemological grounds. More metaphysical considerations need only be invoked when we proceed to consider the evaluation of work in different subdisciplines. At that point, rather than following Habermas and Gadamer, we will turn to the more boldly delineated theories of their predecessors.

166. See supra text aceompanying notes 40-41.

167. GADAMER, supra note 20, at 258-325. He writes: "[Application] is not the subsequent applying to a concrete case of a given universal that we understand first by itself, but it is the actual understanding of the universal itself that the given text constitutes for us." Id. at 305. 
tains an insight that inakes sense according to the evaluator's framework of legal analysis.

As such, applicability is related to the intuitive criterion of originality, ${ }^{168}$ but it captures the essence of this criterion witl more precision. One can be "original" by writing something that is merely weird. Conversely, many excellent works of scliolarship crystallize partially articulated notions, ratlier than achieving tlie sense of novelty that the term "originality" implies. Applicability suggests that the work contains an insight that adds to the evaluator's understanding. To test whether this is so, the operative question is whether the evaluator would apply the work or the idea that it contains in her own thinking process. There are several reasons wliy this might prove impossible, indicating that the work has failed to fulfill the criterion of applicability. First, the work, however original, may be disconnected from the ongoing historical development of the field. Second, it may be fully part of the field, but lack any identifable insight. Third, its insight, although relevant and identifiable, may be too vaguely stated, or too poorly developed, to be imtegrated into the evaluator's thinking.

Just as normative clarity serves as a precondition for persuasiveness in the criteria derived from Habermas, so significance serves as a precondition for applicability. To be applicable, the work must possess the minimal degree of significance; it must fit within the context of legal scliolarship. It need not, however, lave any significance beyond this minimal level; that is, it need not have any noticeable impact on the field. To demand that every work of scholarship be influential, even in its own subject area, is excessively severe. When law school faculties estabhisli a test of this sort for a tenure piece, they are either claiming a false standard for purposes of self-aggrandizement, or falling into the sort of misstatements that result from an mtuitive approach to evaluation. But every work of scliolarship, once it has met the minimuin requirement of significance, should be expected to be apphicable. That is, it sliould contain an identifiable insight that the evaluator can grasp througli application.

While application is far froun an instinctive criterion, it requires a lower level of self-awareness than a judgınent of significance. To determine the significance of a work, one must have an awareness of the field's general contours as they have developed over time. To determine the work's apphicability, one need only be aware of one's present context and be able to relate the work to it. This still requires a fair amount of abstraction. The question is not wliether the evaluator can actually use

168. This is the most common theme in the notoriously sparse writing on evaluating legal scholarship. See Carter, supra note 13, at 2082-83 (non-obviousness); Coombs, supra note 13, at 715 (originality and ambition); Kissam, supra note 13, at 228 (originality); Nelson, supra note 39, at 48590 (unconventionality). 
or cite the work, but whether the work could conceivably be used; that is, whether it contains an identifiable and comprehensible insight.

The criterion of applicability and its relationship to significance can be illustrated by considering Calabresi's book again. ${ }^{169}$ The book's recommendation, while failing the test of persuasiveness, is certainly applicable. One can easily imagine adopting the principle that courts can overrule obsolete statutes and using this principle either im specific areas or for some general theory of government. This conclusion is not particularly satisfying, lowever, because such an application of the book's recommendation is not related to its significance. The siginificance of Calabresi's work lies in its emphasis on statutory interpretation, and this is a concern or sensibility that is not particularly easy to apply. Directly connected with this focus, however, is the insight that obsolete statutes raise a specific interpretive problein which provides a crucial test for one's theory of interpretation. This insight is readily applicable, not only as a citation, but as a theme that indicates a real understanding and appreciation of Calabresi's book. A number of scholars have followed Calabresi in concentrating on the issue of statutory obsolescence and have applied his insight, though without adopting his prescription. ${ }^{170}$

To summarize, Calabresi's book possesses clarity because it articulates its normative prenrise and derives its conclusions from that preinise; it is not convincing, because few people believe that rational public decisionmakers should follow its prescriptions; it is siginificant, because it emerges from the ongoing historical process of legal scholarship and has influenced the development of that process; and it is applicable, at least in part, because it contains insight whose use by other scholars indicates their understanding of its argument.

Another illustration of the applicability criterion is Anthony G. Amsterdam's The Void-for-Vagueness Doctrine in the Supreme Court. ${ }^{171}$ If Warren and Brandeis' The Right to Privacy ${ }^{172}$ is the inost famous law review article ever written, Amsterdam's is the most famous student note. ${ }^{173}$ Amsterdam argues that the void-for-vagueness doctrine not only

169. Calabresi, supro note 148.

170. See, e.g., ESKRIDGE \& FRICKEY, supra note 153, at 844-91; Aleinikoff, supra note 153; Langevoort, supra note 153.

171. Anthony G. Amsterdam, Note, The Void-for-Vagueness Doctrine in the Supreme Court, 109 U. PA. L. REV. 67 (1960).

172. Warren \& Brandeis, supra note 117.

173. Amsterdam's note has been repeatedly cited by the Supreme Court for its insight that vague laws create the danger of unregulated administrative discretion. See, e.g., Papachristou v. City of Jacksonville, 405 U.S. 156, 166 n.8 (1972); Shuttlesworth v. City of Birmingham, 382 U.S. 87,90 n.5 (1965); NAACP v. Button, 371 U.S. 415, 433 n.14 (1963). The note is a familiar academic citation for the same proposition. See, e.g., Robert J. Reinstein \& Harvey A. Silverglate, Legislative Privilege and the Separation of Powers, 86 HARV. L. REV. 1113, 1161 n.238 (1973); Malcolm E. Wheeler, Toward a Theory of Limited Punishment: An Examination of the Eighth Amendment, 24 STAN. L. REV. 838, 856 n.92 (1972). 
fulfills the due process principle of notice, but also serves to restrain the improper exercise of administrative discretion. ${ }^{174}$ Clearly, Amsterdan's note meets the test of minimal significance, for it fits within the context of legal scholarship. It addressed a contemporary doctrine in terms related to the due process revolution of the era, the growing concern with the constitutional regulation of administrative agencies, and the power allocations that occupied the legal process movement. Beyond that, its significance is probably not as great as its faine suggests. Since the control of government discretion was hardly a new theme, the note's influence in identifying that theme is probably limited to the doctrine it discusses. The great virtue of Amsterdain's note is its apphicability. The notion that control of government discretion is one basic element of void-for-vagueness doctrine is an identifiable insight that one can clearly imagine applying to any discussion of that doctrine. ${ }^{175}$ In fact, the note can be said to achieve the highest form of apphicability; applying it not only indicates that the evaluator has understood the work, but that she has understood the doctrine itself.

Like Calabresi's book, Amsterdain's note excels under the criterion of applicability, but fails to meet all the evaluative criteria identified herein. The note does not actually achieve normative clarity; it accepts legal process analysis too readily and fails to identify norns such as popular control or the limitation of individualized oppression as the basis for controlling government discretion. Amsterdam's argument is convincing, however, because one can readily imagine rational decisionmakers acting on it. It is significant, in a limited way, and highly apphicable.

For a work that meets all four criteria, one imight turn to Reich's The New Property. ${ }^{176}$ In Reich's article, the norinative premise is clearly stated; the argument could readily persuade a rational decisionmaker; its significance-both in einerging froin the ongoing development of the field and in infiuencing that development-is great; and it can be apphed in a wide variety of situations. ${ }^{177}$ As for works that ineet none of the

174. Amsterdam, supra note 171 , at 81 .

175. The thesis of the note has been incorporated into the Supreme Court's definitive statement of the vagueness doctrine, see Grayned v. City of Rockford, 408 U.S. 104, 108-110 (1972), which is about as much applicability as an academic could hope for.

176. Reich, supra note 121 .

177. In his illuminating analysis of Fuller and Perdue's The Reliance Interest in Contract Damages, Todd Rakoff considers the various factors that make this article, in his view, a great work of legal scholarship. See Rakoff, supra note 90. Rakoff seems to employ impressionistic, aesthetic criteria. See id. at 215 ("architecture"), 242 (Fuller and Perdue's article "exhibits skills as artistic as they are analytic"). But in justifying or demonstrating his subjective response to these aesthetic virtues, Rakoff relies on criteria similar to those presented here. He speaks about the persuasive quality of the article, $i d$. at 242 , its significance in relation to both contracts scholarship, id. at 22832 , and more general jurisprudential concerns, $i d$. at 223,245 , and its applicability by other legal scholars, id. at 239 ("The more difficult question is whether [Fuller's] approach is definite enough to allow for its use by others in placing newly-arising situations."). He also criticizes the article for a lack of normative clarity. Id. at 213-14; see supra note 95 . With respect to applicability, see also 
criteria, these are plentiful enough to make citation otiose.

\section{III \\ EValuating Works in DifFerent SUbDisciplines}

The two sets of criteria presented in the preceding section are general ones, designed for evaluating any work of prescriptive legal scholarship. They are, however, exphicitly restricted to works within a single subdiscipline, works for which the evaluator and the author share both a common ideology and a common methodology. When this is not the case, the stated criteria cannot be as readily employed. Coinprehension becomes more difficult and judgment less reliable as the gap between the perspectives of the evaluator and the autlior widens.

This difficulty is apparent from the nature of the criteria themselves and from their philosophic sources. Habermas' theory rests upon a concept of communication that presupposes a set of sliared understandings thiat will permit the commumicative process to begin and to proceed. Gadamer's theory depends upon the notion of a shared tradition in which people can locate themselves historically and gauge their relationship to a particular text. To be sure, Habermas and Gadamer also recognize the gaps that may separate individuals, and they devote inuch of their effort to bridging those gaps. Indeed, this is the very point of Habermas' efforts to define rational communication and of Gadamer's image of the fusion of horizons. Both thinkers acknowledge, however, tlrat beyond a certain point, the gaps between people will undermine the communicative process. They recogmize that their theories are directed toward the enterprise of communication or understanding within a single society.

From a global perspective, the differences between legal scliolars are minor, almost trivial. Nonetheless, the evaluative theory proposed in this Article is being constructed by analogy; large theories are being used to generate criteria for a relatively narrow field of study in order to provide empliasis and delineation. Continuing this approach, the relatively sniall differences between different subdisciplines of law will be treated as large ones and will be analogized to tlie differences between entire societies. The point of this approach is not to suggest that legal scholars in different subdisciplines are as far apart as America and the Azande, but to generate criteria tliat take seriously tlie differences tliat do exist. In particular, the goal is to construct an evaluative theory that continues to avoid the pitfalls of opimion and bias in the noore denianding context where an evaluator confronts works from a subdiscipline different froin lier own. The problem is, in sonie sense, the converse of the one involved

Macaulay, supra note 107, at 274-76. Macaulay notes that "The Reliance Interest has influenced American law less than we might expect." Id. at 266. Nonetheless, neither he nor Rakoff substitutes this criterion for genuinely evaluative ones like significance or applicability. 
in evaluating work within an evaluator's own subdiscipline. There, the purpose of the criteria was to generate the distances necessary for judgment; here, the purpose is to bridge the pre-existing distance so that judgment can be deployed responsibly.

This Part identifies two approaches, referred to as sensibilities, for dealing with works outside an evaluator's own subdiscipline. ${ }^{178}$ It apphes these sensibilities to the four criteria for evaluation that were identified above: clarity, persuasiveness, significance, and applicability. The modifications that these sensibilities produce are relevant to two different bodies of scholarship. The first is a distimct subdiscipline, which differs from traditional scholarship and from other dissentmg subdisciplines in both its ideology and methodology. Clearly, the leading cases at present are critical legal studies and law and economics. The second body of scholarship consists of partial subdisciplines which diverge froin traditional scholarship because they are based upon a different methodology or a different ideology, but not both. The leading example of a methodology-based subdiscipline is the law and social science movement; the leading examples of ideology-based subdisciplimes are feminist theory and critical race theory.

\section{A. Approaches to Different Subdisciplines: Doubt and Anxiety}

The problem of evaluating works outside one's own subdiscipline is to cross the conceptual divide that separates one's own views from the views of the author. Naive responses, such as "I know good work when I see it," or "The author has to persuade me," allow free reign for opinion and bias. In academia, opinion is mescapable, and bias becomes an increasing danger as the author's viewpoint diverges from the evaluator's. The problem can be placed in concrete terms by considering the iniportant institutional issue of a tenure decision. Perhaps soine legal academics will feel comfortable summarily dismissing the works of scholars in other subdisciplines. They may even feel comfortable voting against the mitial appointment of a meniber of a particular subdiscipline to their own imstitution on grounds that the entire subdiscipline is invalid. Suppose, however, that such a person is appointed, or that an entrylevel candidate with no scholarly record ends up writing in a different subdiscipline. When this person coines before the faculty for tenure, with a body of work $\mathrm{n} 1$ that subdiscipline, it is surely irresponsible to reject the work categorically and deny the person tenure. In that situation, at least, legal acadenics are obligated to evaluate the works of those in different subdisciplines as fairly and conscientiously as possible.

Scientific positivism provides a siniple solution to this quandary, a

178. See Edward L. Rubin, The Evaluation of Prescriptive Scholarship, 10 TEL AVIV U. STUD. L. 101 (1990) (preliminary discussion of these sensibilities). 
solution that is deeply einbedded in Anglo-American philosophy: the evaluator should identify the truth. Having done so, she can then judge divergent works against that standard. ${ }^{179}$ As previously observed, however, we have no known inethod for discovering the truth in legal scholarship. Many scholars have their own truths, of course, but that is precisely where the problein hes. We need an evaluative theory, a systematic procedure, for evaluating works with which we disagree but cannot satisfactorily disprove.

An alternative solution is suggested by American pragmatism. Pragmatism points toward a consensus theory of knowledge, the view that the trnth is what the community of truth definers says it is. ${ }^{180}$ The crucial question becomes whether one chooses to join or reject the truthdefining community that includes the author of the work. If one chooses to join, at least for purposes of evaluation, one simply adopts the ideology and methodology of the author's subdisciphine and applies the criteria of evaluation as a member of that subdiscipline. If one chooses to reject that commumity of truth definers, the question is whether the work provides any insights for one's own community of truth definers; whether, in the language of pragmatisin, it is of any use.

This is not a particularly satisfactory approach. Expecting the evaluator to make believe that she has different political and inethodological views simply asks too much of her mental flexibility. It adopts an unduly cavalier, imagime-you're-an-ice-cream-cone approach to ideological and methodological commitments. The inquiry into usefulness, on the other hand, is excessively truncated; it substitutes a simplified version of one criterion-applicability-for a comprehensive evaluative process.

A fuller approacli to evaluating works outside one's own subdiscipline can be found in the philosophic antecedents of Haberinas and Gadamer, specifically in Husserl's phenomenology and Heidegger's existential hermeneutics. ${ }^{181}$ One simple advantage of relying on these

179. This is the correspondence theory of truth. See supra note 14.

180. This is the consensus theory of truth. See JAMES, PRAGMATISM, supra note 14, at 95-113; see also FISH, supra note 47 . Stated baldly the theory seems somewhat naive, but its power should not be underestimated. It is probably the working assumption about truth in non-scientific fields, just as positivism or correspondence is probably the working hypothesis in science. To go beyond a consensus theory requires some external or transcendental standard, as continental philosophy suggests. This is not an approach which American scholars adopt very readily.

181. Gadamer explicitly acknowledges Heidegger as the source of his approach. See GADAMER, supra note 20, at 225-34. Heidegger is much less central for Habermas; in fact, critical theory, which is Habermas' direet antecedent, is highly antagonistic to Heidegger. See THEODOR W. Adorno, Negative Dialectics (E.B. Ashton trans., 1973). Nonetheless, the influence of Heidegger is evident in Habermas' discussion of the communal nature of the lifeworld. See 1 HABERMAS, supra note 24 , at $82-83 ; 2$ id. at 113-97.

Husserl is not an acknowledged source of either Gadamer's or Habermas' views; in fact, both take issue with Husserl's depiction of the isolated individual consciousness. See GADAMER, supra note 20, at 214-22; 1 HABERMAS, supra note 24, at 129-30. But Husserl has been highly influential in both works; in some sense, his attack on scientific positivism is the seminal work for the entire 
sources is that they can be readily related to the criteria identified above since they einerge froin the same intellectual tradition. More importantly, Husserl and Heidegger offer transcendental theories that specifically reject the positivist inodel of truth. ${ }^{182}$ Whatever we beheve about the relevance of those theories to problems of knowledge in the natural sciences, they seem particularly promising for legal scholarship. The caution, once agam, is that Husserl and Heidegger are being used only by analogy, to solve an epistemological problein. Their actual work is metaphysical and addresses issues far beyond those implicated by the evaluation of scholarly work.

As stated above, the critique of methodology, to which the epistemologies of Habermas and Gadamer belong, begins from the premise that people are immersed in their own individual experience or lifeworld, which is structured by their cultural context. ${ }^{183}$ The evaluative criteria that have been proposed are derived from this perspective. In asking how the evaluator uses the criteria for a work outside her own subdiscipline, the question we confront is how we escape or transcend this context in which we are so fully and decisively immersed. This is the problem Husserl and Heidegger confront in their metaphysics. Beginning from one's total immersion in one's life experience, an immersion which structures one's thought and indeed makes thinking possible, how does a person start upon the path toward transcendental insights? Something must set the process going, something that coines to us within our life experience and yet points us beyond that experience.

For Husserl, one goes beyond one's hife experience by becoming conscious of it as experience. This consciousness, referred to as an epoché or bracketing, ${ }^{184}$ is triggered by the process of doubt. Doubt comes to us,

critique of methodology. Both Gadamer and Habermas can be regarded as advancing solutions to the problems posed by Husserl: determining a source of validity apart from scientific positivism, and thus explicating the connectiou between physical and social conditions and the experience of the individual.

182. See, eg., Heidegger, supra note 43, at 67-78; MARTIN Heidegger, Modern Science, Metaphysics and Mathematics, in BASIC WrITINGs 247 (David F. Krell ed., 1977); MarTIN HEIDEgGeR, The Question Concerning Technology, in BASIC WRITINGS, supra, at 287; HUSSERL, supra note 35, at 3-135; HUSSERL, supra note 42, at 45-86.

183. See supra text accompanying notes 51-53. For specific discussions, see HeIDEgGER, supra note 43, at 149-224; HUSSERL, supra note 42, at 91-100.

184. HuSSERL, supra note 35, at 135-55; HuSSERL, supra note 42, at 96-100, 171-93. This is not an easy concept to describe or summarize, and Husserl devoted considerable effort to combating misconceptions. See Maurice Natanson, EdMund Husserl: Philosopher Of INFINITE TASks 42-62 (1973). One of Husserl's clearer descriptions runs as follows:

We put out of action the general thesis which belongs to the essence of the natural standpoint, we place in brackets whatever it includes respecting the nature of Being: this entire natural world therefore which is continually "there for us", "present to our hand", and will ever remain there, is a "fact-world" of which we continue to be conscious, eveu though it pleases us to put it in brackets.

...

Thus all sciences which relate to this natural world, though they stand never so firm to me, though they fill me with wondering admiration, though I am far from any thought of 
Husserl points out, in the midst of the natural attitude, that is, our ordinary life experience: we doubt the truth of soineone's statement or the reliabihty of our own behefs. ${ }^{185}$ These moinents of doubt serve as triggers for the transcendence that Husserl is striving to achieve. Suppose, he says, one chooses to doubt not this or that thing within the world that one experiences, but the world in its entirety and the self that is observing it. ${ }^{186}$ The world and the self reinain present, but the nature of their presence is no longer assumed or taken as given. ${ }^{187}$ Through a process that begins with doubt, we bracket the world and go beyond our natural experience of it.

Heidegger, hike Husserl, begins with a consciousness that is totally immersed-or, to use his terminology, "thrown"-into the everyday world. ${ }^{188}$ This world is inherently social and the individual is "one of the guys," a ineinber of the "crowd." 189 What triggers the quest for deeper understanding is anxiety or "care"-specifically, the anxiety engendered by one's own finitude. ${ }^{190}$ For the individual, death is a termination of personal experience, a confrontation with the contours of existence that no level of immersion in the crowd can set aside. Like doubt, death is a common sensation within ordinary life experience, and Heidegger invites

objecting to them in the least degree, I disconnect them all, I make absolutely no use of their standards, I do not appropriate a single one of the propositions that enter into their systems, even though their evidential value is perfect, I take none of them, no one of them serves me for a foundation.

HUSSERL, supra note 42, at 110-11, quoted in NATANSON, supra, at 56-57.

185. HUSSERL, supra note 42 , at 91-96.

186. Id. at 96-100. Husserl writes:

We can attempt to doubt anything and everything, however convinced we may be concerning what we doubt, even though the evidence which seals our assurance is completely adequate.

... We link on here, but add directly and emphatieally that this attempt to doubt everything should serve us only as a device of method . . . .

Id. at 97 (order of sentences reversed); see also HUSSERL, supra note 35, at 157-89.

187. HuSSERL, supra note 42, at 99-100; see also HuSSERL, supra note 35, at 148-52.

188. HEIDEGGER, supra note 43, at 78-148, 219-24. Heidegger also speaks of a "falling" into the world. Id. at 219-24. Although he denies the apparent theological connotations of this term, he associates it with inauthenticity, which is akin to a loss of grace. Heidegger is emphatic that inauthenticity is not a lack of Being but a mode of Being, the mode associated with everyday life: " 'Fallenness' into the 'world' mcans an absorption in Being-with-one-another, in so far as the latter is guided by idle talk, curiosity, and ambiguity." Id. at 220 .

189. Id. at 153-68, 219-24. Heidegger uses the German word Man, which is translated as "one" or, more commonly, "they." Id. at 164 . Speaking of "the they," as the translation does, is awkward, at best. For example: "Distantiality, averageness, and levelling down, as ways of Being for the 'they', constitute what we know as 'publicness'." Id. at 165 . Colloquialisms like "one of the guys" or "the crowd" can seem trivializing, but they capture the tone of Heidegger's discussion. For example:

In utilizing public means of transport and in making use of information services such as the newspaper, every Other is like the next. . . . In this inconspicuousness and unascertainability, the real dictatorship of the "they" is unfolded. We take pleasure and enjoy ourselves as they [man] take pleasure; we rcad, see, and judge about literature and art as they see and judge....

Id. at 164.

190. Id. at 274-311. 
us to build upon this sensation. It provides a pathway, in his view, to a recognition of our Being, the primordial state of existence where true meaning resides. ${ }^{191}$

Although Husserl and Heidegger proceed in markedly different directions, their respective treatments of doubt and anxiety bear strong similarities. At a simplified, analogical level these similarities seem to predominate. The difference between the two, as pathways from the otherwise closed world of ordimary experience, reflects the differences between Husserl's and Heidegger's philosophic visions. For Husserl, doubt is an intellectual experience, a conscious decision to question what was heretofore accepted. The bracketing or epoché that springs from doubt is thus an act of will, an intellectual effort to understand preempirical meaning. ${ }^{192}$ Heidegger's concept of care or anxiety appeals inore to the emotions. It springs froin our well-recognized fear of death, not from our desire for understanding, and coines to us against our will in moments of "uncanniness." 193 In other words, doubt is a consciously adopted mindset, while anxiety is a response elicited by experience.

Doubt and anxiety are not, by theinselves, criteria for evaluation. They are too vague and too remote from judgments of intellectual quality or excellence to serve that purpose. Rather, they should be regarded as sensibilities that can accompany and modify the evaluative criteria identified above. There is, to be sure, a need for sensibihity or judgment in deciding whether any work is normatively clear or persuasive, significant or apphicable; none of these criteria can be reduced to a formula or an equation. But doubt and anxiety are stronger, more self-evident sensibilities which can modify particular criteria when these criteria are being used to evaluate works im a different subdisciphine.

The point of invoking, or more precisely, of developing these sensibilities is that they come to the evaluator where slie is; that is, in the midst of her own viewpoint or subdiscipline. When confrontmg a work in a different subdiscipline, she need not clioose between off-liand rejection and coinplete surrender. Ratlier, slie can become aware of the doubts and anxieties about her own approach that the autlior's work

191. Id. at 311 ("[A]nticipation reveals to Dasein its lostness in the they-self, and brings it face to face with the possibility of being itself... in an impassioned freedom towards death-a freedom which has been released from the Illusions of the 'they', and which is factical, certain of itself, and anxious.').

192. See HUSSERL, supra note 42 , at 97 ("The attempt to doubt everything has its place in the realm of our perfect freedom."). The transcendental epoche, Husserl further states, can be achieved "only through a total change of the natural attitude, such that we no longer live, as heretofore, as human beings within natural existence, constantly effecting the validity of the pre-given world; rather, we must constantly deny ourselves this." HUSSERL, supra note 35, at 148.

193. HEIDEGGER, supra note 43, at 233-34 ("In anxiety one feels 'uncanny' ... . This uncanniness pursues Dasein constantly, and is a threat to its everyday lostness in the 'they' . . . Anxiety can arise in the most innocuous Situations."). 
induces, and use those sensibilities as a guide in deploying the evaluative criteria.

More specifically, doubt is a purposive questioning of one's own beliefs, engendered by the confrontation with a work that embodies different ones; anxiety, a less conscious response, refers to a sensation of uncertainty or wrongness about those beliefs. Both impulses suggest an openness about one's own work, a willingness to stand apart from it and see it as inerely one position ainong many. Husserl might say that the evaluator "brackets" her own views, that she consciously strives to hold them in abeyance. Heidegger's framework suggests that the evaluator respond to her anxiety by bringing her views into contact with their own limitations. In both cases, there is a dialectical relationship between the works of the author and those of the evaluator. The doubts and anxieties that the author's work creates about the evaluator's indicates to the evaluator that the author's work is valuable or ineritorious. Instead of assessing the work directly, the evaluator ineasures its value by considering the effect of this work on her own work, and on her own subdiscipline. The approach may seem elhiptical. It emerges, however, from the well-recognized notion that people are only knowledgeable about their own experience, that the nature of things truly foreign to us can only be determined within the ambit of that experience.

Doubt and anxiety, once triggered, need not lead the evaluator to the conviction that her beliefs are incorrect. "Conversion" experiences of this sort are relatively rare in academics. Rather, the test is whether the evaluator experiences sufficient doubt or anxiety so that she must persuade herself that she is right. If one finds oneself rehearsing one's prior arguments, or articulating refutations in one's inind, or searching assiduously for new ways to justify one's conclusions, then a work which generates such responses should be judged to be of value. Thus, the very process of formulating counter-arguinents, which is a mechanism for outright rejection of the author's work when uncritically perforined, becomes a datum for assessing that work's quality in the context of a more disciphined evaluative theory.

It should be noted that the same sensibilities that enable the evaluator to approach works in a different subdiscipline also provide a means of advancing one's own subdiscipline. By employing doubt or responding to anxiety, one can generate new research problems or gain a better understanding of those that have arisen. This process resembles Festinger's notion of cognitive dissonance, ${ }^{194}$ or Kuhn's depiction of nor1nal science in descriptive disciplines. ${ }^{195}$ According to these writers, the world presents us with discordant information, and the test of our theory is its ability to absorb and organize that information into our explanatory

194. Leon Festinger, A Theory of Cognitive Dissonance (1957).

195. KUHN, supra note 35. 
system. Here, the stimulus is not information or data but scholarly works with different premises and methods. By becoming conscious of the doubts and anxieties that those works engender we can not only evaluate those works in a conscientious manner, but also gain insights for carrying our own efforts forward.

\section{B. Complete Subdisciplines}

The operation of doubt and anxiety, as modifying sensibilities, can be inade more concrete by considermg their use. At present, two bodies of legal scholarship clearly qualify as subdisciplines that are distinct both from each other and from standard legal scholarship, in the sense that they possess a different ideology and a different methodology. These are law and economics and critical legal studies.

While many uses can be made of economic analysis in law, one particnlar approach has flourished as a well-defined, self-consciously separate mode of legal reasoning. Sometimes referred to as the Chicago School, it rests on the ideological or normative position that the law should be economically efficient. ${ }^{196}$ This approach is directly relevant only im certain areas of law, and some law and economics scholars are content to restrict their efforts to that realm. Others argue that virtually any legal problem can be reduced to an analysis of costs and benefits, and that society should adopt the policy that yields the greatest benefit according to this calcnlus. ${ }^{197}$ In either case, the method of analysis is microeconomics. Sometimes this is employed on an informal basis that is readily comprehensible to any educated person, but in many cases the analysis is sophisticated and difficult to follow without economic training.

Critical legal studies proceeds from the ideological or normative premise that social class stratification and hierarchical power distributions, as they exist in our society, are inherently unjust. ${ }^{198}$ As an empirical matter, the proponents of critical legal studies see the legal system as an instrumentality of this injustice. To demonstrate this position and to generate alternatives, critical legal studies rehes on a philosophic approach that blends neo-Marxism, deconstruction, and critical theory.

196. See, e.g., POSNER, supra note 2; Ellickson, supra note 26; Kornhauser, supra note 2 (characterizing law and economics); Richard A. Posner, Utilitarianism, Economics and Legal Theory, 8 J. LEGAL STUD. 103 (1979).

197. See, e.g., Gary S. Becker, The Economic Approach to Human Behavior (1976); Gary S. BeCKer, A TREATISE on the Family (1981); Posner, supra note 113.

198. See, e.g., Gerald E. Frug, The City as a Legal Concept, 93 HARV. L. Rev. 1057 (1980); Duncan Kennedy, The Structure of Blackstone's Commentaries, 28 BUFF. L. REV. 205 (1979); Karl E. Klare, Judicial Deradicalization of the Wagner Act and the Origins of Modern Legal Consciousness, 1937-1941, 62 MiNn. L. ReV. 265 (1978); Gary Peller, Race Consciousness, 1990 Duke L.J. 758; William H. Simon, Visions of Practice in Legal Thought, 36 STAN. L. REv. 469 (1984). 
In essence, it analyzes legal texts to demonstrate that their claims to coherence and objectivity are false, and that they are in fact designed to perpetuate the existing social and political systein. While this methodology is inore diffuse than that of law and economics, it too has been used in a technical and sophisticated way that makes it relatively inaccessible to scholars who are unfamiliar with it. ${ }^{199}$

The use of doubt and anxiety as sensibilities that nodify the criteria for evaluation can be explored by considering the application of the four criteria to the subdisciplines of law and economics and critical legal studies. With respect to the first criterion, normative clarity, these sensibilities should not be used at all. Legal scholars should hold works from a different subdiscipline to precisely the same standard of clarity as works within their own subdiscipline. There is no reason why works from a different subdiscipline should not be clear about their norinative preinises. More precisely, there is no reason why they should not be sufficiently clear that those premises are understood by those who do not share thein. ${ }^{200}$

In fact, it can be argued that works in a different subdiscipline should be held to a higher standard of clarity. The reason for this goes back to the basis of the clarity criterion. Scholarship should be communicative action, designed to reach understanding with its audience, not strategic action that attempts to deceive, confuse, or otherwise achieve a desired effect by non-communicative means. While econonic or philosophic analysis can be difficult for standard legal scholars to understand, understanding becomes unnecessarily nore difficult if the premises of the analysis are unstated or obscured. Stating the premises does not impede or compromise the analysis in any way; it siniply articulates the author's real starting point.

Both critical legal studies and Chicago School scholarship demonstrate the need for a criterion of clarity because their adherents often einploy strategic behavior in the interest of persuasion. Critical legal studies articles have argued that the law is incoherent and that this incoherence indicates the need for radical social change. ${ }^{201}$ In fact, the connection between incoherence and the need for change can only be made by adding the desirability of sucli change as an unstated norin. The inco-

199. Cf. Andrew altman, Critical Legal Studies: A liberal Critique (1990). Altman argues that the methodological aspect of critical legal studies is not present in all of the works generally associated with this movement. See id. at 18-19. For a critique of this position, see Balkin, supra note 29.

200. See Abrams, supra note 16, at 1030-51 (similar argument concerning feminist narrative scholarship); see also infra note 223.

201. See, e.g., Boyle, supra note 1; Clare Dalton, An Essay in the Deconstruction of Contract Doctrine, 94 YALE L.J. 997 (1985); Mark Kelman, Interpretive Construction in the Substantive Criminal Law, 33 Stan. L. Rev. 591 (1981); Gary Peller, The Metaphysics of American Law, 73 CALIF. L. REv. 1151 (1985); Singer, supra note 1; Mark V. Tushnet, Following the Rules Laid Down: A Critique of Interpretivism and Neutral Principles, 96 HaRv. L. Rev. 781 (1983). 
herence of legal doctrine demonstrates, at most, the need for political decisions, not the content of those decisions. One can readily understand why critical legal scholars would be tempted to obscure this point. If the incolierence of doctrine demonstrates the need for radical cliange as a practical matter, then all those who recognize this incoherence, including legal realists, many conservatives, and some traditional scholars, would be enlisted in the critical scholars' cause. But the effort to do this is strategic, not communcative, because it conceals an operative nonn. Critical legal studies articles that recognize this norm-that explicitly embrace the political position favoring radical change-and then argue for it are superior as legal scholarship.

Many law and economics articles, particularly those affiliated witl the Chicago School, suffer from this same defect. Economics is a general discipline that can be used to analyze and implement a variety of social objectives. But there has been a tendency among scholars who employ this discipline to argue that economics indicates the superiority of the free market over other modes of social organization. As is frequently poirted out, this argument ouly succeeds by incorporating an independent norm in favor of efficiency; ${ }^{202}$ if social equity or redistribution are adopted as the norm, economic analysis leads to different recommendations. In addition, even if one accepts the norm of efficiency, the occurrence of market failure means that the free market is not always the best way to achieve this goal. Thus, in order to resolve issues involving market failure, arguments for the free market often incorporate another unstated norn, namely, the desirability of the free market itself. These arguments are all strategic efforts to sell the free market to those who do not accept either the free market or efficiency in general, by treating the free market as the only rational approach to social organization.

Holding works in these subdisciplines to a general standard of normative clarity serves as an antidote to strategic action, and it does so without seriously burdening or disadvantaging the work under consideration. It may be difficult to persuade someone with whom one disagrees, but it is not particularly burdensome to state the source of the disagreement. Indeed, an evaluator who reacts liostilely to divergent views is likely to experience a sense of relief when the basis of the divergence is identified. Slie will generally be open to acknowledging the difference, even if she is not open to the arguments that flow from it. Conversely, scholars in different subdisciplines slould liave no difficulty articulating their normative premises. In fact, since they are not in the mainstream and are necessarily conscious of this, their premises will be thrown into relief, and they should be able to articulate these premises more readily than standard legal scliolars.

202. See, e.g., ACKERMAN, supra note 26, at 92 n.18; Coleman, supra note 26, at 248-49; Dworkin, supra note 2. 
It is in relation to the criterion of significance that doubt and anxiety become relevant. To approach a work in a separate subdiscipline, the evaluator must first decide upon the significance of that subdiscipline; that is, its relationship to the ongoing developinent of legal scholarship. This is a threshold question that enables the evaluator to recognize the character of the work in question and decide upon the appropriate evaluative stance. Should the evaluator's lack of agreement or understanding be taken as an indication that the work fails to ineet the evaluative criteria, or should it be seen as a reason to be cautious and inodulate her own reactions? Clearly, a work is not entitled to respect simply because it begins from different premises and uses a different methodology. The problein here is not one of sympathy or kindness, but of assessing the amount of credence that should be given to a particular subdiscipline for evaluative purposes.

One answer, which can be directly derived from the criterion of significance, is that a particular subdiscipline is entitled to respect if it relates to ongoing scholarly work in the field as a whole. A simple way of making this determination is to assess the number of adherents that the subdiscipline possesses and the breadth of their representation in law school faculties and academic journals. As a practical matter, this is probably sufficient, at least in a relatively open society like our own. As a theoretical inatter, however, it is nothing inore than a consensus theory of validity. The real question is not whether the subdiscipline has had an effect upon the field, but whether it should have an effect.

The sensibilities of doubt and anxiety provide a ineans of making this determination. A particular subdiscipline should be regarded as significant in its entirety if it engenders doubt or anxiety among outsiders about their own approach. Critical legal studies and law and economics clearly qualify, for they represent the leading challenges to standard legal scholarship, and have generated doubt and anxiety across a broad spectrum of academia. Because each of these approaches is based on a distinct ideology and a distinct methodology which are connected in an organic way, each offers a comprehensive, alternative mode of legal analysis. The doubt or anxiety generated by a sincere and open confrontation with these subdisciplines (or by their confrontation with each other) applies to both the evaluator's norms and methods and, cumulatively, to her basic vision of the law. The response they generate involves a questioning of the evaluator's entire analytic framework and an increased clarity about that framework's contours. This is particularly important for standard legal scholarship because, as the dominant mode of analysis, its practitioners tend to assune the validity of their norms and methods. The significance of critical legal studies and law and economics can be measured by their ability to challenge these assumptions and present an alternative vision of legal analysis. 
For a subdiscipline that the evaluator judges to be significant, the evaluative criteria of significance, persuasiveness, and applicability acquire a different character. The significance of a particular work is to be ineasured by asking whether the work is significant within its own subdiscipline; that is, the threshold question of significance has been answered by the subdiscipline as a whole, and the significance of the work is to be assessed within that context. This is a determination that can generally be inade directly. Through conscientious effort, the evaluator should be able to distinguish a work which articulates a inajor theme or initiates a new hine of inquiry from one which is irrelevant within its field. The tendency to underestimate the significance of work because it is in a different subdisciphine can be counteracted by the recognition that the subdiscipline is significant as a whole.

Once the significance of the subdiscipline has been established, the sensibilities of doubt and anxiety also inodify judgments of persuasiveness and apphicability with respect to the specific work under consideration. A scholar who does not belong to the subdiscipline of critical legal studies or law and economics is likely to employ these evaluative criteria with inappropriate harshness. Moreover, a great deal of subjectivity is involved in these judgments, and the process is likely to be seriously clouded by normative and methodological disagreenents between the evaluator and the author. The potential for bias due to differences in norms and inethodology-while severe-should not be overeinphasized, however. Persuasiveness and apphicability are not purely subjective criteria. The operative question is not "Am I persuaded?" or "Can I apply it?" but "Would a rational decisionmaker be persuaded?" and "Does the work contain an insight that scholars could apply?".

The most deferential approach to a separate subdiscipline would displace judgnients of quahity in their entirety with assessinents of doubt or anxiety. The evaluator would ask whether the work creates doubts im her mind about whether her own arguinents would be persuasive to a rational decisionmaker; she would consider whether the work produced a sudden, "uncanny" sense that her own approach was only one ainong inany, and might not be viewed by outsiders as the most convincing one. Similarly, the evaluator would ask whether the work engendered doubts that her own work could be apphed by other scholars, whether it really contained insights that would make sense to others and ainplify their understandimg. An evaluator who felt that the work's subdiscipline should be accorded great respect would stop once these doubts and anxieties were ehicited and declare the work to be ineritorious on that basis alone. The less deferential approach would use these same doubts and anxieties to temper independent judgments of persuasiveness and applicability, rather than displacing such judgments in their entirety. Thus, a work would be given more credit for meeting these two criteria if it 
engendered such doubts or anxieties. The choice of approach ultimately depends upon the evaluator's judgment. But the evaluator should state that judgment explicitly; this alone serves as a partial antidote to opinion and bias. The conscientious effort to accord at least some deference to any separate, significant subdiscipline, and thus to allow some admixture of doubt and anxiety im making judgments of persuasiveness or apphicability, then serves as a further antidote.

One can better understand the evaluative process described above by looking at an example: evaluation of Gerald Frug's critical legal studies piece, The City as a Legal Concept, ${ }^{203}$ by an evaluator who does not share Frug's views. Once the significance of critical legal studies is recogmized, the significance of Frug's article within its subdiscipline is not difficult to discern. The article is a classic application of the basic critical legal studies position to a previously unexplored topic. It argues that the subordinate legal status of cities emerges from a liberal ideology that reinforces the power of the ruling group and disempowers intermediate communities. The article unified various strands of commumitarianism already present in critical legal studies scholarship, and by articulatimg them in terms of local government, it helped generate a whole body of "localist" writing within this subdiscipline. Moreover, anyone reading the article, even if they do not share its normative premises, should experience doubt about the persuasiveness and applicability of more traditional explanations.

Theodore Lowi, in contrast, identifies the same phenomenon as Frug, bemoaning the fragmentation of metropolitan areas into inefficient, racially unequal subumits. ${ }^{204}$ But Lowi ascribes this phenomenon to the growth of bureaucratic government and the "end of liberalism," an explanation that the standard legal scliolar will find more congenial. ${ }^{205}$ It seems difficult to avoid the gnawing doubt that Frug has perceived a deeper, more powerful, more disconcerting cause than Lowi's dyspeptic but domesticated criticisms. All Lowi offers is a jeremiad about the complexities of modern society and a condemnation of its inevitable accoutrements, like bureaucracy, centralization, and the delegation of power. Frug's analysis attacks the moral basis of our entire pohtical regime. For him, the ineffectuality of urban government is not simply a by-product of the misfortune that cities somehow grew too large, but an example of our general disempowerment of the poor, the newly arrived, and the ethnically diverse. ${ }^{206}$ On these grounds, Frug's article deserves to be held in

203. Frug, supra note 198.

204. Theodore J. LOWI, The END of Liberalism: The SeCond Republic of the UnIted STATES (2d ed. 1979).

205. See id. at xv-xvi.

206. Frug, supra note 198, at 1067-70. 
high regard, even by those who find themselves in disagreement with his political perspective.

\section{Partial Subdisciplines}

Not all legal scholarship that diverges from the mainstream employs both different norms and a different methodology. In a number of important cases, the divergence is limited to one category or the other. For example, the law and social science movement employs a different methodology without possessing any distinct norm, such as efficiency or social transformation. In general, the norms of those who adopt this methodological approach fall within the same range as those of mainstream scholars. This may also be said of law and hterature and of practical reason, to the extent that the latter represents a distimct methodology. In fact, the search for new ways of approaching law has become so widespread and insistent that these various movements can be seen as elements of the mainstream itself. The absorption of this methodological dispersion into the mainstream tradition does not, however, obviate the problem of evaluation. A scholar who rehes heavily on social science, for example, will find himself confronted with works that use techmiques of doctrinal analysis or literary criticism to reach their conclusions. While the barrier of normative disagreement may be absent, or not systematically present, a sense of unfamiliarity is difficult to avoid.

The converse situation obtains in feminist ${ }^{207}$ and critical race tlieory. ${ }^{208}$ These works are animated by norms that clearly diverge from those of mainstream scholars. They are more closely allied to critical legal studies, arguing that the existing social system and its attendant ideology are oppressive and elitist. But they ascribe this oppression to racial or gender inotivations, often sweeping critical legal studies itself into the category of the condemned. ${ }^{209}$ A great virtue of this literature is that it meets the umiversal criterion of normative clarity smce its divergence from the premises of mainstream scholarship is stated with vigor

207. The following list is exemplary, but certainly not comprehensive: CATHERINE A. MacKinnon, Toward a Feminist TheORY of THE STATE (1989); Bartlett, supra note 22; Lucinda M. Finley, Transcending Equality Theory: A Way Out of the Maternity and the Workplace Debate, 86 Colum. L. REv. 1118 (1986); Herma Hill Kay, Models of Equality, 1985 U. ILL. L. REv. 39; Sylvia A. Law, Rethinking Sex and the Constitution, 132 U. PA. L. REv. 955 (1984); Martha Minow, The Supreme Court, 1986 Term-Foreword: Justice Engendered, 101 HARV. L. REv. 10 (1987); Sherry, supra note 22; Carol Weisbrod, Practical Polyphony: Theories of the State and Feminist Jurisprudence, 24 GA. L. REv. 985 (1990); West, supra note 22.

208. Again, an exemplary list: BELL, supra note 12; WilliaMs, supra note 12; Regina Austin, Sapphire Boundl, 1989 WIS. L. REv. 539; Anthony E. Cook, Beyond Critical Legal Studies: The Reconstructive Theology of Dr. Martin Luther King, Jr., 103 HARv. L. REv. 985 (1990); Crenshaw, supra note 20; Delgado, supra note 21; Harris, supra note 22; Lawrence, supra note 20; Christine A. Littleton, Reconstructing Sexual Equality, 75 CALIF. L. REv. 1279 (1987); Matsuda, supra note 22.

209. See Cook, supra note 208; Dalton, supra note 21; Richard Delgado, The Ethereal Scholar: Does Critical Legal Studies Have What Minorities Want?, 22 HARV. C.R.-C.L. L. REv. 301 (1987); Matsuda, supra note 22. 
and precision. Unlike critical legal studies or law and economics, feminist and critical race theory display no tendency to disguise their norms as empirical arguments in a strategic effort to persuade. Instead, these works consciously separate theinselves on normative grounds, in part because this very separation is an element of their substantive position.

Feminist and critical race theory often claim a distinct methodology as well. In fact, no such inethodology is apparent at this stage in the development of these approaches. Instead, the claim to a separate inethodology seems to be part of their respective ideological stances. It is certainly sensible to assert that someone who rejects mainstream norms should also reject mainstream inethods and employ a separate inethodology, but that claim does not constitute a methodology unless it is actuated in the scholarship itself. Feminist and critical race theory in practice tend to deploy their norms to offer alternative analyses of substantive issues rather than a new inethodology. ${ }^{210}$

This is illustrated by a certain disjunction between the way these approaches characterize their work and the actual analysis that they present. For example, in Mari Matsuda's article, Looking to the Bottom: Critical Legal Studies and Reparations, ${ }^{211}$ the declaration of a different inethodology is followed by an essentially doctrinal argument that reparations should be recognized within our current legal framework. Another leading work in critical race theory, Regina Austin's Sapphire Boundl, ${ }^{212}$ beginis with a research program for black women scholars that involves a broad appeal to black woinen generally. ${ }^{213}$ But the article proceeds to analyze an appellate case in familiar terms, prescribing a different result by asserting different norms from those the judge employed.214 Similarly, Christine Littleton's Reconstructing Sexual Equality ${ }^{215}$ offers a reinterpretation of Title VII and of the legal concept of equality that einerges froin a different norm, but uses familiar analytic methods. Katharine Bartlett's discussion of "feminist legal methods," although it seems to declare a separate methodology, recognizes the doctrinal dispersion of this scholarship and assimilates its distinct features to

210. See Dennis Patterson, Postmodernism/Feminism/Law, 77 CORNELl L. REV. 254 (1992); Jeanne L. Schroeder, Abduction from the Seraglio: Feminist Methodologies and the Logic of Imagination, 70 TEX. L. REV. 109 (1991); Joan C. Williams, Deconstructing Gender, 87 MicH. L. REv. 797 (1989). Professors Patterson, Schroeder, and Williams argue that many feminist scholars have failed to produce adequately emancipatory visions because they have remained committed to conventional methodologies. Of course, the mere political desirability of new methodology will not generate that methodology. Conversely, political programs do not necessarily demand new methodologies; they can be maintained, although obviously not proved, within the context of some (although not necessarily all) existing methodological approaches.

211. Matsuda, supra note 22.

212. Austin, supra note 208.

213. Id. at 539-49.

214. Id. at 549-76.

215. Littleton, supra note 208. 
the practical reason movement. ${ }^{216}$ Jerome Culp's demand for black scholarship focuses on important questions of issues and perspective, but not on basic methodology. ${ }^{217}$

The closest approach to a separate methodology in feminist and critical race theory lies in the concept of narrative. ${ }^{218}$ This technique draws on the observation that women and minorities have had different life experiences from white males, experiences that centrally involve marginalization and oppression. The point of narratives-accounts of personal experience-in feminist and critical race literature is that a society which subjects women and minorities to these experiences must change in profound ways that white male scholars, even those affiliated with critical legal studies, do not perceive. ${ }^{219}$ Exphcit recogintion of these experiences im legal scholarship, the willingness to speak in an individual, rather than a depersonalized, objective voice, could conceivably evolve into a separate method. But method, as discussed above, consists of an interlinked set of consciously articulated procedures that generates research. ${ }^{220}$ To date, narrative has not developed to this poimt; it func-

216. Bartlett, supra note 22. Bartlett canvasses a variety of methods, including the "rational/ einpirical position" (using standard legal analysis on its own terms), id. at 868-72, "standpoint epistemology" (asserting that women occupy a privileged position for assessing oppression), id. at 872-77, "postmodernism" (questioning the reality of existing concepts), $i d$. at 877-80, and "positionality," a belief in "situated and partial" truth that she associates with the practical reason movement, id. at 880-87. A related approach, discussing the contextual nature of feminist critique, is Deborah L. Rhode, Feminist Critical Theories, 42 STAN. L. REv. 617 (1990). For general works focusing on practical reason, see Steven J. Burton, Law as Practical Reason, 62 S. CAL. L. REv. 747 (1989); Eskridge \& Frickey, supra note 153; Daniel A. Farber \& Philip P. Frickey, Practical Reason and the First Amendment, 34 UCLA L. REV. 1615 (1987); Anthony T. Kronman, Alexander Bickel's Philosophy of Prudence, 94 YALE L.J. 1567 (1985); Frank I. Michelman, The Supreme Court, 1985 Term-Foreword: Traces of Self-Government, 100 HARV. L. REV. 4 (1986); Richard A. Posner, The Jurisprudence of Skepticism, 86 Mich. L. REV. 827 (1988).

217. Jerome M. Culp, Jr., Toward a Black Scholarship: Race and Original Understandings, 1991 DUKE L.J. 39.

218. See, e.g., Bell, supra note 12; SUSAN Estrich, REAL RAPE 1-7 (1987); Williams, supra note 12. For discussions of this methodology, see Robert M. Cover, The Supreme Court, 1982 Term-Foreword, Nonios and Narrative, 97 HARv. L. REv. 4 (1983); Richard Delgado, Storytelling for Oppositionists and Others: A Plea for Narrative, 87 MICH. L. REV. 2411 (1989); Richard Delgado, supra note 22; Kim L. Scheppele, Foreword: Telling Stories, 87 MiCH. L. REv. 2073 (1989) (foreword to symposiun on legal storytelling). For an illuninating discussion of feminist narrative, see Abrams, supra note 16.

219. See Jerome M. Culp, Jr., Autobiography and Legal Scholarship and Teaching: Finding the Me in the Legal Academy, 77 VA. L. REV. 539 (1991). As Culp points out, the impersonal voice of white inale scholars is no less political; what is involved is a conflict of normative positions.

220. See supra text accompanying note 25 . It is possible that a methodology based on narrative could evolve from Ricoeur's notion of social life as a text. See Ricoeur, supra note 48; see also PAUL. Ricoeur, The CONFLICT OF INTERPRETAtions (Don Ihde ed., 1974). This would involve some means of categorizing personal experience and sonie set of interpretive techniques for deriving conclusions from those experiences.

Another possible direction for the development of a new methodology might involve the use of dialogue and fable. See, e.g., BELL, supra note 12. This approach, used as a technique by philosophers such as Plato and Bishop Berkeley, has the virtue of being linked to traditional methods of legal pedagogy. Its developinent into a inethod would require rules for constructing 
tions as a specific technique for the presentation of substantive views, not as a comprehensive system that generates its own scholarly approach. ${ }^{221}$ It is not, for example, equivalent to the deconstructive arguments that characterize critical legal studies scholarship or to the microeconomic analysis of the Chicago School. ${ }^{222}$

None of this is necessarily a criticism of feminist or critical race studies, or of law and social science for that matter. Normative positions need not be accompamed by separate methodologies, and separate methodologies are certainly not required to establish separate norms. The reason for pursuing this issue is that it has imphications for the evaluative process. In particular, a work belonging to a partial subdiscipline-one which diverges from the evaluator's own approach in its norms or methodology, but not in both-is separated from the evaluator by a somewhat narrower divide than a work belonging to a completely different subdiscipline. That does not obviate the need to modify the evaluative criteria with doubt and anxiety, but it does affect the extent to which these sensibilities should be employed.

Thus, partial subdisciphines, in addition to being judged by the saine standard of normative clarity that apphes to all legal scholarship, ${ }^{223}$ should also be judged by the evaluator's own standard of significance. This is in contrast to works belonging to a coinplete subdisciphine, where the judgment of significance is applied to the subdiscipline itself and the significance of the work is then assessed within the context of that subdiscipline. The reason for this differentiation is that a work which einploys only a different method or a different norm reinains more connected with mainstream scholarship. An evaluator can inquire whether the use of such a norm or method einerges from the ongoing developinent of the

dialogues and deriving meaning from them. For a celebrated example in the modern context, sec Henry M. Hart, A Dialogue on the Power of Congress to Limit the Jurisdiction of Federal Courts, in Paul M. Bator et al., Hart and Wechsler's The Federal Courts and the Federal SYSTEM 393-423 (3d ed. 1988).

221. See, e.g., Toni M. Massaro, Empathy, Legal Storytelling, and the Rule of Law: New Words, old Wounds?, 87 MICH. L. REv. 2099 (1989); Steven L. Winter, The Cognitive Dimension of the Agon Between Legal Power and Narrative Meaning, 87 MiCH. L. REV. 2225 (1989).

222. Moreover, narrative has been used by mainstream scholars with some frequency. See, e.g., Curtis J. Berger, Away from the Court House and into the Field: The Odyssey of a Special Master, 78 CoLUM. L. REv. 707 (1978) (detailing author's experience as Special Master in a school desegregation suit); Norval Morris, Ake Dah, 52 U. CHI. L. REv. 553 (1985) (telling story set in early 20th-century Burma to introduce substantive themes in criminal law); Norval Morris, The Veraswami Story, 52 U. CHI. L. Rev. 948 (1985) (same); Philip G. Schrag, On Her Majesty's Secret Service: Protecting the Consumer in New York City, 80 YALE L.J. 1529 (1971) (recounting author's 15-month tenure with the New York City Department of Consumer Affairs' Law Enforcement Division).

223. See Abrams, supra note 16, at 1030-51. Professor Abrams argues that feminist narratives are unnecessarily vague about their normative stance. While this literature should definitely not be judged as if it were a new version of traditional legal scholarship, she argues, it could elicit a more sustained, respectful scholarly exchange through "normative elaboration" of its arguments. See id. at $1045-48$. 
field. An academic field, after all, is not a specific, substantive point of view. Rather, it is the set of beliefs and practices that constitutes an entire subject and creates the evaluator's context, her fore-structure of understanding. As sucl, the field incorporates a certain normative and methodological dispersion. Indeed, it is the interaction of different norms and different metlodologies thiat makes up mucli of the field's vitality. One would be hard pressed to find any topic in the field that did not involve a clash of norms or methods.

It is the linkage of a distinct norm and a distinct methodology that places a body of legal scholarship beyond the reach of inainstream judgments of significance. This linkage produces a body of work that is distinct from inainstream scholarship in a sharply defined way, and that creates its own coinprehensive context for tlose who follow it. Partial subdisciplines do not share these features, and a inainstream evaluator can inake judgnients about their significance. For example, she can ask whether Matsuda's argument for reparation ${ }^{224}$ emerges from the ongoing developinent of the field, or exercises any influence on it. One would tend to conclude that the reparation issue lias subsided in importance, and that the article's arguments are too familiar and diffuse to resurrect it. 225 Even within the mainstreain tradition, the approach to racial justice has gone beyond concepts of monetary compensation and has focused on issues of structural cliange. ${ }^{226}$ In contrast, Austin's analysis, ${ }^{227}$ however traditional in method, strikes a major theine. She argues that, in one case, ${ }^{228}$ the presiding appellate judges imposed their own personal perspectives-white and inale, but more significantly middleclass-on a group of inner-city, black teenage girls, without justifying that perspective or determining the girls' perspective on the issue. ${ }^{229}$ Austin's article joins a body of work that challenges the reflexive assumptions of empowered decisionmakers and their ability to deal with citizens of different genders, ethnicities, and social status. ${ }^{230}$

224. Matsuda, supra note 22.

225. For comprehensive treatments, see, e.g., Boris I. BITTKER, The CASE for Black Reparations (1973); Vine Deloria, JR., We TAlK, You Listen 198-209 (1970).

226. See, e.g., Symposium, Civil Rights in Mississippi, 57 Miss. L.J. 589 (1987); Symposium, The Fair Housing Act After Twenty Years, 6 YALE L. \& PoL'y Rev. 331 (1988); Symposium, Section 1983: The Constitution and the Courts, 77 GEO. L.J. 1437 (1989).

227. Austin, supra note 208.

228. Chambers v. Omaha Girls Club, 629 F. Supp. 925 (D. Neb. 1986), aff'd, 834 F.2d 697 (8th Cir. 1987).

229. In Chambers, an unmarried, black instructor at a predominantly black Girls Club became pregnant. She was dismissed pursuant to the Club's "Negative Role Model Policy," which dictated that "single persons who become pregnant or cause a pregnancy would no longer be permitted to continue employment at the Girls Club." Id. at 929. The instructor challenged her dismissal in a Title VII suit, but the court held for the defendant Girls Club that "[the] articulated reason for the rule, i.e., to provide positive role models in an attempt to discourage teenagers from becoming pregnant, is a legitimate, nondiscriminatory reason ...." Id. at 947.

230. See generally sources cited supra notes 207-08. 
Mainstream evaluators can judge the significance of works in partial subdisciplines directly. But they would need to modify their judgments of persuasiveness and apphicability when dealing with these works. The divergence in norms or methods, although not enough to separate works in a partial subdiscipline from the ongoing developinent of the field, does create an impediment to fair and balanced assessment of these two criteria. Scholars generally have a stake in their own norms or methods; they will tend to conclude that a work with different ones should not be persuasive to a rational decisionmaker, or would not be applicable by other scholars. This tendency, while it may be somewhat stronger when both normative and methodological differences operate simultaneously, is likely to prevail where either difference is present. One might suppose that a divergence in norms has greater inpact. But scholars often have strong commitments to their inethods as well as their norms, since the value of their life's work may depend on the method they have chosen.

As in the case of a complete subdiscipline, doubt and anxiety can be used as a virtual substitute for judgments of excellence, or they can be given a more limited role as a means of modifying those judgments. Ultimately, the evaluator inust decide. In the absence of a separate assessinent of the subdiscipline's significance, this decision must be guided by an assessment of the particular work's significance within the inainstream, and by the strength of the doubts and anxieties it generates. As Mary Coombs suggests, femimist and critical race scholarship often consciously serve to generate doubt and anxiety, with the expectation that these reactions will lead to understanding. ${ }^{231}$ This effort should be met with a corresponding willingness by mainstream scholars to be open to, or conscious of, such reactions, and to recogmze them as an indication of the scholarship's value. ${ }^{232}$

As an example of work with a different methodology froin inainstream scholarship, the pohtical science literature, which uses judge's political positions to predict their decisions, ${ }^{233}$ has been linnited in its effect on legal scholarship because it ignores the normative and conceptual elements of law. Thus, the doubts and anxieties it has generated have been miminal, and an evaluator can decide directly whether a particular work is persuasive or applicable. In contrast, the public choice analysis of legislators seems quite powerful, because it raises questions

231. Coombs, supra note 13 , at 693-703.

232. This effort to elicit a particular response may appear to possess a strategic quality, but, in fact, it is fully communicative. The response that is being elicited is one that aids understanding, or, more precisely, one that constitutes a component of understanding. If the response seems somewhat less than rational, in Habermas' terms, it is because understanding across a cultural, or even a subcultural barrier, may not be entirely amenable to the kinds of rational processes Habermas describes.

233. See, e.g., David W. Rohde \& Harold J. SPAETH, SUPreme CoURT DECISION MaKing 134-71 (1976); GLENDON SCHUBERT, THE JUdiCIAL MiND: THE ATTITUDES AND IDEOLOGIES OF SUPREME COURT JUSTICES, 1946-1963 (1965). 
about legislative intent, delegation, and statutory interpretation that are central to contemporary legal thought. ${ }^{234}$ In these cases, the doubts and anxieties generated by the divergent inethodology of these scholars have been taken inore seriously. Evaluators can use these sensibilities to modify, or even displace, their own judgments of the work's persuasiveness or applicability.

With respect to norms, a particularly notable example is Catherime MacKinnon's book, Toward a Feminist Theory of the State. ${ }^{235}$ The book uses a familiar mode of legal argument and it is not difficult to evaluate its considerable significance within the general field. More difficult to judge, for someone who does not share MacKinnon's normative position, is the persuasiveness or applicability of her work. MacKinnon's cliaracterization of sexual relations between inen and women is so harsl, and her claims about the pervasiveness of their effects so extensive, that one tends to assume that no decisionmaker would be persuaded by her and that no scliolar who did not already agree with lier substantive positions would find ler insiglits useful. But such judgments need to be lieavily tempered, precisely because she is so extreme, and tlius hikely to elicit extreine reactions. Her views on sexual harassinent, for example, seein more persuasive and more applicable if one uses doubt about one's own reactions, or recogmizes a personal reaction as an anxiety indicating the force of ler argument. To soine extent, the use of these sensibilities involves the translation of lier sweeping indictinent of society into a prescription for more inodest incremental change. That is, elements of MacKinnon's view seein persuasive or applicable because one is substituting doubt or anxiety about one's own norms for an acceptance of MacKinnon's norms. But it is precisely such inulti-leveled implications of a work that allow an evaluator to recognize it as excellent, even if that evaluator disagrees with its preimises.

The adaptation of the evaluative criteria for works in partial subdisciplines helps illuminate the recent controversy over Randall Kennedy's article, Racial Critiques of Legal Academia. ${ }^{236}$ Kennedy claims that certain ininority scholars are asserting that they occupy a privileged position on racial issues. In his view, there is a single standard of inerit, and these scholars must be judged by it. ${ }^{237}$ Critics respond that there is indeed a distinct voice of color, and that Kennedy's rejection of that voice reflects the same dominance of majoritarian views that minority scliolars are cliallenging. ${ }^{238}$ This response has been both voluminous and impas-

234. See, e.g., Daniel A. Farber \& Philip P. Frickey, Law and Public Choice: A Critical INTRODUCTION (1991); Aranson et al., supra note 159; Easterbrook, supra note 153; Macey, supra note 153.

235. MacKinnon, supra note 207.

236. Kennedy, supra note 5.

237. Id. at 1787-807.

238. See sources cited supra note 6. 
sioned, but it seems that Kennedy and his critics are talking past each other.

The preceding discussion suggests a way of understanding these competing claims. Kennedy's critique is directed to the criterion of significance, while the responses of his critics are directed to the criteria of persuasiveness and applicability. Kennedy asserts that the significance of individual works of minority scholarship, specifically critical race theory, should be determined in the context of legal scholarship as a whole, rather than by being judged only against works with similar views. This argument seems correct. Critical race theory is only a partial subdiscipline; although it is based on distinctive norms, it lacks the distinctive methodology that characterizes critical legal studies or law and economics. It relies on familiar methods of analysis and fraines familiar arguments to support its distinctive premises. Consequently, inainstream scholars can judge its significance directly. A work of critical race theory can be evaluated in terms of its relationship to the ongoing development of legal scholarship.

For exainple, inainstreain scholars can readily perceive that Richard Delgado's argument in favor of excluding racial epithets froin First Amendment protection contributes directly to the ongoing development of the field. ${ }^{239}$ Even someone who disagrees with Delgado should acknowledge his argument as part of the general reevaluation of free speech issues, the claim that civility and access are principles of equivalent importance. ${ }^{240}$ Similarly, the evaluator should have no diffculty recognizing that Delgado's article, in applying this body of thought to racial issues, represents an important event in the argument's evolution.

But if Kennedy is correct about the criterion of significance, his critics are correct about the criteria of persuasiveness and applicability. These criteria should be mediated by doubt and anxiety whenever the work being evaluated is based on different normative premises from those of the evaluator. The norms of critical race theory differ dramatically from those of mainstream scholars, and its critical stance renders the disagreement particularly stark. Every work derived from identifiable norms contains a tacit condemnation of divergent views, but the condemnation of critical race theory is explicit. More siguificantly, it is directed at mainstream evaluators themselves, and at norms that govern their evaluation. To evaluate the persuasiveness or applicability of such work,

239. Richard Delgado, Words that Wound: A Tort Action for Racial Insults, Epithets and NameCalling, 17 HARV. C.R.-C.L. L. REV. 133 (1982).

240. See, e.g., Donald A. Downs, Nazis in Skokie: Freedom, Community, and the First Amendment (1985); Donald A. Downs, The New Politics of Pornography (1989); Paul Brest \& Ann Vandenberg, Politics, Feminism, and the Constitution: The Anti-Pornography Movement in Minneapolis, 39 STAN. L. REv. 607 (1987). 
the evaluator needs some process of self-reflection and self-doubt. Otherwise, the tendency to dismiss the work as impractical and intennerate is simply too great.

While a theory of evaluation cannot resolve the debate about Kennedy's article, it does place that debate in context. The issue that seems to separate Kennedy froin his critics is whether there exists a "distinctive voice of color."241 As Alex Johnson points out, this does not mean that every scholar of color must speak in this voice. ${ }^{242}$ Styles of American legal scholarship generally reflect conscious choices, not the reflexive views of distmct subcultures. The claim, rather, is that there is a group of minority scholars who have chosen to adopt a different approach from their inainstream counterparts. ${ }^{243}$ To decide this issue, of course, it is necessary to decide what counts as a difference. The relevant issue is the standard of evaluation-whether it should be the saine for critical race theory as it is for mainstreain scholarship. This im turn can only be answered once we agree upon those standards, and it may be answered differently for different standards. The answer proposed here is that critical race theory shares the methodology of mainstream scholarship, and thus is not sufficiently different to require a different standard for assessing its significance. But this scholarship does arise froin norms that are sufficiently different to demand a modified approach in judging their persuasiveness and applicability.

This solution may seem nnsatisfactory in its failure to offer a definitive answer, but it does respond to some of the inajor concerns that have been raised on each side of the debate. It assures critical race scholars that their work should not be judged by the specific standards they are criticizing, that mainstream scholars should subject theinselves to a process of self-reflection before hazarding judgments. At the same time, it assures mainstream scholars that judginent remains possible, that they are not disabled from making assessments about the quahity of the work they are reading. This simnltaneous recognition of difference and preservation of the urnversality of the evaluative enterprise is precisely what a theory of evaluation is designed to achieve.

\section{CONCLUSION}

At stake in the effort to develop a theory for evaluating legal scholarship is communication and understanding. One might even say, soinewhat grandiosely, that what is at stake is the concept of truth. Truth in

241. See Kennedy, supra note 5; Johnson, The New Voice of Color, supra note 6; Johnson, Racial Critigues, supra note 6.

242. Johnson, The New Voice of Color, supra note 6, at 2012-20; Johnson, Racial Critiques, supra note 6, at 149-55.

243. Johnson, The New Voice of Color, supra note 6, at 2020-39; Johnson, Racial Critiques, supra note 6 , at $155-60$. 
this context does not mean some objective or demonstrable set of propositions. As Habermas and Gadamer argue, that kind of truth is simply not available-in fact, not meaningful- $m$ the human sciences. Law is a huinan science in this sense: its purpose is not to describe physical phenomena, but to understand our own legal system and formulate prescriptions for it. If there is a truth $\mathrm{m}$ legal scholarship, it must be found in the process of understanding that a theory of evaluation generates.

The theory proposed in this article is grounded in the phenomenological experience of the individual evaluator. It establishes four criteria that the evaluator can einploy while committed to her own norms and methods: (1) clarity, the extent to which the work identifies its normative premises; (2) persuasiveness, the extent to which the evaluator believes the work should convince the public decisionmakers whom it addresses; (3) significance, the extent to which the work relates to the ongoing development of the field; and (4) applicability, the extent to which the evaluator beheves that the work contains an identifiable insight that could be used by other legal scholars. The first two criteria are derived from Habermas' theory of communicative action; the remaining two, from Gadamer's hermeneutic theory.

These criteria can be employed when the evaluator is dealing with a work in her own subdisciphne; that is, a work that shares her own normative and methodological framework. As the work becomes more foreign, and hence more threatening to the evaluator, the individual judgment which is required in order to use these criteria becomes less reliable. There is no mechamical solution to this problem. A theory of evaluation can channel and discipline judgment but cannot replace it. One way to deal with a divergent work is to use the doubts and anxieties that such a work generates as a means of tempering one's judgment. Thus, the work's ability to encourage doubt about one's own beliefs or to elicit anxiety that those beliefs are incorrect should be taken as a presumptive indication of its quality and a guide to altering the operation of the evaluative criteria. The criterion of clarity should never be modified because those with divergent views should be expected to state the basis of their disagreement. Sigmificance should be modified only when confronting a work whose linked normative and methodological framework places it in a separate subdiscipline. This is because the criterion of significance determines the work's relationship to the ongoing development of the field, and should be modified only if the work can claim a comprehensive framework of its own. Persuasiveness and applicability, however, should be inodified whenever one is confronting a work that uses different norms or methods. By being open to one's own doubts or anxieties, the ability of the criteria to control opinion and bias can be increased, and fair, productive evaluation of divergent scholarship becomes more likely. 
Clearly, the proposed criteria represent only one possible way of constructing a theory of evaluation. The final and most important point is that we need a theory of soine sort. Without a theory, any scholar, no inatter how conscientious, will fall prey to opinion and bias. It is simply iinpossible to hold one's prejudices in abeyance if one has only nothingness to deploy in their place. Without a theory, we are lost in a trackless forest, banging and stumbling into one thing after another, and reacting with unreflective anger or delight. A theory provides altitude, a way of gaining some perspective on one's own position, its relationship to others, and the structure of the field as a whole. Such a theory is the real path to understanding - the one that hes beyond a positivist conception of truth. 
